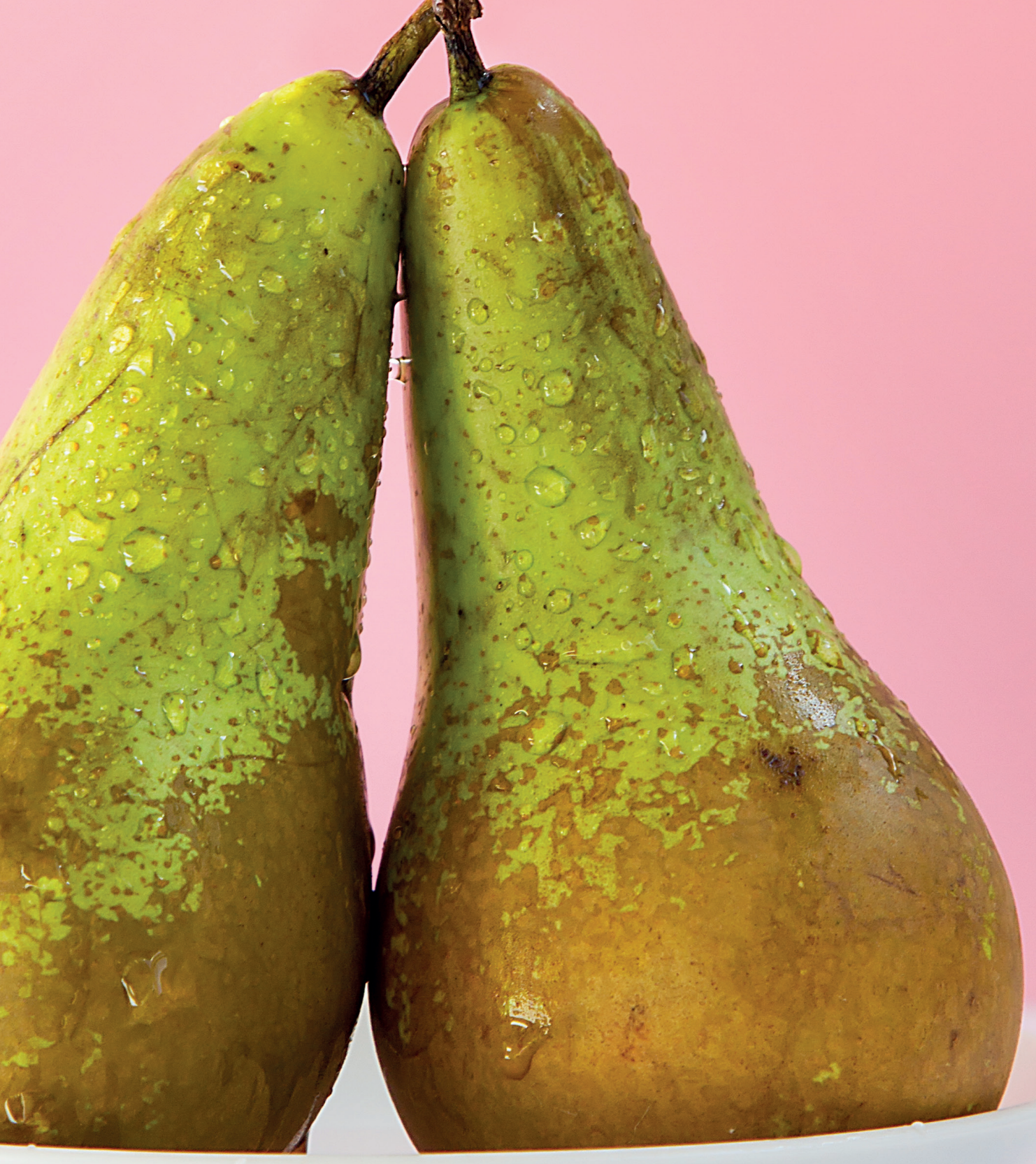

\title{
Humistatus Peer
}

Eindrapportage Werkgroep Peer 



\title{
Humistatus Peer
}

\author{
Eindrapportage Werkgroep Peer
}

Auteurs: Bastiaan Brouwer, Frank van de Geijn, Jan Verschoor, Edo Wissink, Esther Hogeveen

Instituut: Wageningen Food \& Biobased Research

Dit onderzoek is uitgevoerd door Wageningen Food \& Biobased Research en Wageningen Plant Research in opdracht van het Ministerie van Landbouw, natuur en voedselkwaliteit en gefinancierd door Topsector Tuinbouw \& Uitgangsmaterialen, in het kader van PPS TU16025 Humistatus: topkwaliteit uit duurzame bewaring door inzicht in vochtstatus (BO-49-002-001 (projectnummer 6234126800).

Wageningen Food \& Biobased Research

Wageningen, december 2020

Vertrouwelijk

Rapport 2097

\section{WAGENINGEN}

UNIVERSITY \& RESEARCH 
Versie: definitief

Vertrouwelijk tot en met: juli 2021

Reviewer: Hans de Wild

Goedgekeurd door: Nicole Koenderink

Opdrachtgever: het Ministerie van Landbouw, natuur en voedselkwaliteit

Financier: Topsector Tuinbouw \& Uitgangsmaterialen

(C) 2020 Wageningen Food \& Biobased Research, instituut binnen de rechtspersoon Stichting Wageningen Research.

Vertrouwelijk rapport. Uit deze uitgave mag niets worden gereproduceerd en/of openbaar gemaakt zonder voorafgaande schriftelijke toestemming van de directeur van Wageningen Food \& Biobased Research. Vanaf augustus 2021 is dit rapport gratis te downloaden op https://doi.org/10.18174/537206 of op www.wur.nl/wfbr (onder publicaties).

Postbus 17, 6700 AA Wageningen, T 03174800 84, E info.wfbr@wur.nl, www.wur.nl/wfbr. Wageningen Food \& Biobased Research is onderdeel van Wageningen University \& Research.

Alle rechten voorbehouden. Niets uit deze uitgave mag worden verveelvoudigd, opgeslagen in een geautomatiseerd gegevensbestand of openbaar gemaakt in enige vorm of op enige wijze, hetzij elektronisch, hetzij mechanisch, door fotokopieën, opnamen of enige andere manier, zonder voorafgaande schriftelijke toestemming van de uitgever. De uitgever aanvaardt geen aansprakelijkheid voor eventuele fouten of onvolkomenheden. 


\section{Inhoud}

$\begin{array}{lr}\text { Woord vooraf } & 5\end{array}$

$\begin{array}{lr}\text { Samenvatting Humistatus } & 6\end{array}$

$\begin{array}{llr}1 & \text { Introductie algemeen } & 10\end{array}$

$\begin{array}{lll}1.1 & \text { Aanleiding en doel } & 10\end{array}$

$\begin{array}{lll}1.2 & \text { Globale aanpak project } & 10\end{array}$

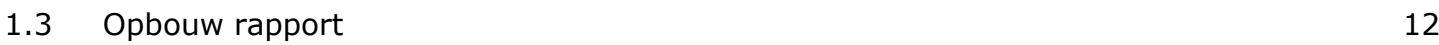

2 Definitie en ontwikkeling meetmethode humistatus $\quad 13$

2.1 Introductie $\quad 13$

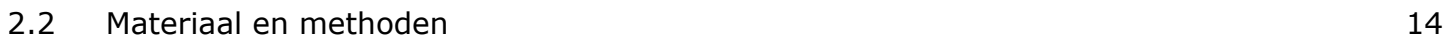

$\begin{array}{lll}2.3 & \text { Resultaten en discussie } & 15\end{array}$

2.3.1 Validatie modellen slappe nek seizoen 2018-2019 16

2.3.2 Modellering op basis van data seizoen 2019-2020 18

$\begin{array}{ll}2.3 .3 & \text { Voorspelling van vochtverlies }\end{array}$

$\begin{array}{lll}2.4 & \text { Conclusie } & 22\end{array}$

3 Invloed (na-)oogstfactoren en bewaarregime op vochtstatus (praktijk) 23

3.1 Introductie $\quad 23$

$\begin{array}{lll}3.2 & \text { Fusttype en vochtverlies } & 23\end{array}$

$\begin{array}{lll}3.2 .1 & \text { Doel } & 23\end{array}$

3.2.2 Inleiding en eerdere onderzoekservaringen 23

3.2.3 Materiaal en methode 23

3.2.4 Resultaten $\quad 24$

$\begin{array}{lll}3.2 .5 & \text { Conclusie } & 25\end{array}$

$\begin{array}{ll}3.3 & \text { Invloed van herkomst }\end{array}$

3.3.1 Doel 25

3.3.2 Inleiding $\quad 25$

3.3.3 Materiaal en methode $\quad 26$

$\begin{array}{lll}3.3 .4 & \text { Resultaten } & 26\end{array}$

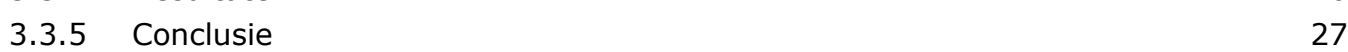

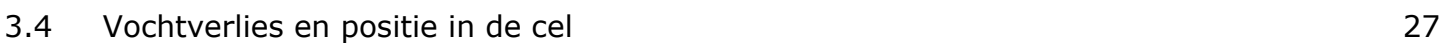

$\begin{array}{lll}3.4 .1 & \text { Doel } & 27\end{array}$

$\begin{array}{lll}3.4 .2 & \text { Inleiding } & 27\end{array}$

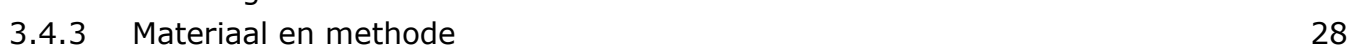

$\begin{array}{lll}3.4 .4 & \text { Resultaten } & 28\end{array}$

$\begin{array}{lll}3.4 .5 & \text { Conclusie } & 30\end{array}$

4 Sensoren voor humistatus en klimaat in cel $\quad 31$

$\begin{array}{lll}4.1 & \text { Introductie } & 31\end{array}$

$\begin{array}{lll}4.2 & \text { Sensorkandidaten om humistatus te meten } & 31\end{array}$

4.3 T en RV metingen $\quad 32$

4.3.1 Inleiding $\quad 32$

4.3.2 Materiaal en methode $\quad 32$

4.3.3 Resultaten $\quad 34$

4.3.4 Conclusie $\quad 36$

$\begin{array}{lll}4.4 & \text { Ultrasone afstandmeter } & 36\end{array}$

$\begin{array}{lll}4.4 .1 & \text { Inleiding } & 36\end{array}$

$\begin{array}{lll}\text { 4.4.2 } & \text { Eerdere onderzoekservaringen } & 36\end{array}$

$\begin{array}{lll}4.4 .3 & \text { Resultaten } & 38\end{array}$ 
5 Invloed van koelsysteem op de intensiteit en stabiliteit van de koelactie tijdens bewaring

5.2 Opzet/aanpak 42

5.2.1 Achtergrond $\quad 42$

5.2.2 Uitvoering 44

5.2.3 Nauwkeurigheid en reactietijd temperatuurmetingen 46

$\begin{array}{lll}5.3 & \text { Resultaten } & 47\end{array}$

5.3.1 Analyse over alle uitgevoerde metingen $\quad 47$

5.3.2 Nut van combineren van meettechnieken $\quad 50$

5.3.3 Temperatuurmetingen van $\mathrm{NH}_{3}$-pompsysteem in volle bewaarcel (meting 7) 52

5.3.4 Temperatuurmetingen van R404A DX-systeem in volle bewaarcel 53

5.3.5 Temperatuurmetingen van $\mathrm{CO}_{2} \mathrm{DX}$-systeem in transportcel 54

5.4 Conclusies/discussie en planning $\quad 55$

$6 \quad$ Conclusies en aanbevelingen $\quad 56$

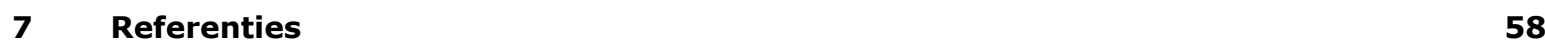

$\begin{array}{lr}\text { Bijlage 1. Grafieken T en RV meting } & 59\end{array}$ 


\section{Woord vooraf}

Voor u ligt het eindrapport van het Publiek-Private Samenwerkingsproject Humistatus Werkgroep Peer. In 2016 is de reis gestart om het werk dat onder andere 10 jaar eerder in het Kwalicon project uitgevoerd is, voor te zetten. Vochtgerelateerde problemen bij peren, maar ook bij andere verse producten blijft een lastig te beheersen probleem waar eens goed in gedoken moest worden.

Samen met de partners uit de praktijk hebben we een, mijns inziens, uniek project uitgevoerd waarbij vanuit alle hoeken naar de problematiek gekeken is. Uiteindelijk zijn er vele puzzelstukjes gelegd en zien we beter wat er op verschillende momenten gedaan kan worden om strakke en gezonde peren te houden tijdens bewaring. Dit rapport beschrijft een samenvatting en aanbevelingen op basis van het totale onderzoek. De experimenten van de eerste 2 seizoenen zijn in een tussenrapport beschreven (Brouwer et al., 2019). Daarnaast worden met name de experimenten van het laatste seizoen in detail beschreven.

Ik wil alle partners heel hartelijk danken voor hun financiële bijdrage, maar zeer zeker ook voor hun bijdrage aan de uitvoering van de experimenten, beschikbaar stellen van materialen en expertise, de reacties op resultaten, discussies over de impact en wat het praktisch betekent en ook voor het stimuleren van nieuwe ideeën en inspiratie.

Daarnaast wil ik het onderzoeksteam bedanken voor het mooie werk wat er geleverd is. Het is niet altijd makkelijk geweest om alle onderdelen uit te voeren op de manier zoals we die voor ogen hadden. Het blijft een uitdaging bij onderzoek met vers product dat zich altijd anders gedraagt dan verwacht, en onderzoek dat deels in de praktijk uitgevoerd wordt waardoor er factoren zijn die je niet allemaal in de hand hebt. Toch hebben we mooie heldere resultaten gerealiseerd waar zeker op verder gebouwd kan worden.

Esther Hogeveen-van Echtelt

Projectleider Humistatus 


\section{Samenvatting Humistatus}

Vochtgerelateerde problemen bij versproducten, zoals schimmel en fysiologisch bederf, leiden tot waarde- en gewichtsverlies. Opvallend is dat deze problemen sterk partijspecifiek optreden. Het PPSproject Humistatus zoekt, voor de lange bewaring van peren, naar manieren om partijspecifiek vochtverlies en vochtgerelateerde problemen beter voorspelbaar en beheersbaar te maken om zo verliezen te voorkomen.

Bij bewaring van peren is het fenomeen "slappe nek" een symptoom van uitgedroogde peren, terwijl diverse typen bewaarrot kunnen optreden bij te vochtige condities. Huidige controle van vochtcondities in bewaarcellen vindt op dit moment plaats door het wekelijks meten van condenswater (ontdooiwater van verdamper). Hiermee wordt een beeld verkregen van het vochtonttrekkingsgedrag van de cel per periode. Dit geeft echter nog steeds verrassingen na bewaring o.a. vanwege partijverschillen en locatie-invloeden in de cel, welke tot nu toe niet te voorspellen zijn.

Uitgangspunt bij aanvang van dit project was het idee dat 1) de vochtstatus bij inslag, 2) de gevoeligheid voor uitdroging, én 3) de (lokale) condities na oogst/in de bewaarcel samen bepalend zijn voor de kans om slappe nekken te ontwikkelen. En dat deze factoren te meten zijn en samen de humistatus van een partij vormen.

Binnen het project is gewerkt om meer balans te krijgen in sturing van partijen peren ter voorkoming van deze problemen o.a. door:

- Definitie en begrip van de actuele vochtspanning/humistatus van een partij.

- Het ontwikkelen van een meetmethode en/of sensor om de humistatus van een partij te kunnen karakteriseren bij oogst en te volgen gedurende bewaring.

- Meer inzicht in de invloed van verschillende teelt- en bewaarfactoren op de humistatus van peren.

- Ontwikkeling van protocollen/mogelijkheden om te sturen op kwaliteit met de diverse technieken.

Dit rapport beschrijft de belangrijkste resultaten van de verschillende experimenten binnen de werkgroep Peer, die gedurende de 3 bewaarseizoenen zijn uitgevoerd. In een tussentijdsrapport ${ }^{1}$ zijn de resultaten van de eerste 2 seizoenen uitgebreid beschreven. In dit rapport wordt hier kort op terug gekeken en worden de resultaten van het derde jaar toegevoegd. In deze samenvatting worden de belangrijkste inzichten beschreven van het hele project.

\section{Karakterisering humistatus van een partij en invloed van teeltmaatregelen}

- De volgende factoren vertonen correlaties met vochtverlies en/of slappenek-score na bewaring.

- Percentage brons (hoger percentage brons, meer slappe nek en meer uitdroging)

- Vorm van de peren-nek (slanke nek, meer slappe nek)

- Vruchtmaat in gewicht of beeldoppervlak (kleinere peren, meer slappe nek)

- Oplosbare suikers (lagere Brix, meer uitdroging)

Dit is bepaald op basis van metingen aan (individuele) peren na oogst afkomstig van 1 boom, uit diverse droogtestress- en bemestingsbehandelingen en uit analyse van verschillende partijen met specifieke eigenschappen.

- Deze informatie is samengevat in twee modellen:

- Een gevorderd model voor voorspelling van het risico op slappe nekken

- Een beginnend model voor voorspelling van mate van vochtverlies tijdens bewaring

- Het vochtverlies tijdens bewaring van een partij en de slappenek-score tonen in meerdere experimenten opvallend genoeg geen sterke correlatie in de experimenten. Eerst werd gedacht dat de beperkte variatie in slappenek-score van de bemonsterde partijen en de

\footnotetext{
${ }^{1}$ Brouwer et al., 2019. Report 1985 "Resultaten experimenten Humistatus 2017-2019. Tussenrapportage Werkgroep Peer" Wageningen Food \& Biobased Research.
} 
classificatieschaal van deze score hier een belangrijke rol in speelden. Na het laatste seizoen lijkt het erop dat de variatie in brons en nek het grootste deel van de variatie in vochtverlies en slappe nekken tussen partijen verklaren. Wel is het nog steeds zo dat vochtverlies een toename van de slappenek-score tot gevolg heeft.

- $\quad$ r is een positieve correlatie gevonden tussen het procentuele vochtverlies in de beginperiode van bewaring (of na een stress-test) en het uiteindelijke vochtverlies gedurende bewaring van dezelfde partijen peren. Dit geeft aan dat de eigenschap van partijen peren om vocht te verliezen al vroeg in de bewaring is te bepalen.

- Teeltbehandelingen door middel van droogtestress en/of extra bemesting met kaliumnitraat hebben in de experimenten tot minder grote verschillen geleid in o.a. maat, vochtstatus en uiteindelijk bewaarresultaat, dan verwacht. Hier zijn een aantal mogelijke verklaringen voor:

- De wortels van de bomen in de proefveldjes met beperkte watergift hebben waarschijnlijk meer water kunnen opnemen dan verwacht door bredere wortelgroei (resultaat "Teelt de grond uit", Rien van der Maas, WPR).

- Alle peren van deze locatie (herkomsten A en B in seizoen 2019-2020) hebben relatief een laag percentage brons, een dikke nek en een grote maat, wat een relatief lage gevoeligheid voor slappe nek voorspelt (zie model). Daarnaast werden deze factoren niet beïnvloed door de beperkingen in watergift.

Invloed van externe factoren gedurende oogst/bewaring op vochtverlies en slappe nekken De afgelopen 3 seizoenen zijn ook experimenten uitgevoerd (met name in de praktijk) om de invloed van externe factoren gedurende oogst/bewaring op het vochtverlies en slappe nekken of rotpercentage van een partij te bepalen. Belangrijke inzichten hiervan zijn:

- De mate van vochtverlies en slappenek-score kunnen sterk verschillen per herkomst. $\mathrm{Er}$ is een positieve correlatie tussen vochtverlies en slappenek-score (meer vochtverlies, hogere slappenekscore), echter het vochtverlies kan niet als een directe voorspelling gebruikt worden voor slappe nek, er zijn te veel partijen die zich anders gedragen.

- Dompelen is zeer effectief gebleken in het beperken van het gewichtsverlies tijdens de bewaring. Vergelijk van gewichtsverlies tussen cellen met gedompelde en nietgedompelde peren toonde dit aan. Dompelen beperkte het gewichtsverlies tot onder de $1 \%$ netto gewichtsverlies tegen een verlies van 1.5 tot $3 \%$ bij niet gedompelde peren. Dit lagere verlies lijkt verklaart te worden door het op kistniveau extra beschikbare vocht (vaak 5-7 liter) als gevolg van het dompelen. In deze proef zijn steeds plastic kisten met elkaar vergeleken. Door het gebruik van verschillende cellen met steeds een andere herkomst kan een (beperkt) deel van het vastgestelde verschil ook aan herkomst/cel worden toegewezen. Het lijkt mogelijk om met het dompelen het vochtverlies onder het niveau van $1.0 \%$ te brengen. Hiernaast lijkt de spreiding in gewichtsverlies binnen de cel bij toepassing van dompelen kleiner.

- $\quad$ De impact van een hogere inkoeltemperatuur tijdens de eerste 8 dagen na inslag op het vochtverlies, beperkt zich tot alleen een hoger vochtverlies in die periode. In de opvolgende perioden lijkt de hogere inkoeltemperatuur geen verdere versterking te geven van het vochtverlies. Het vertraagd inkoelen van het product door het een nacht buiten af te laten koelen geeft iets versterking van het gewichtsverlies in de eerste dagen van de bewaring, maar het gewichtsverlies neemt niet extra toe tijdens verdere bewaring.

Beide bevindingen komen overeen met het idee dat vochtverlies grotendeels een fysisch verschijnsel is en dat schilweerstand in de tijd niet sterk verandert (uitgezonderd bij rot).

- Getracht is met het in een specifieke periode afdekken van kisten de impact van een vochtig klimaat, in een bepaalde periode tijdens de bewaring, op vochtverlies enerzijds en rotontwikkeling anderzijds, in beeld te brengen. Voor deze experimenten gold dat:

- De periode van afdekken van open plastic kisten geen significante verschillen geeft in vochtverlies tussen de tegengestelde objecten. Bijvoorbeeld wachten met afdekken van kisten tot het moment van starten CA-condities geeft nauwelijks extra vochtverlies.

- Het laat (na 6 maanden) afdekken een gelijk beeld in vochtverlies geeft, maar wel een opvallend hoger rotpercentage. Mogelijk is het laat afdekken een extreme behandeling geworden, doordat bij het laat afdekken ook condens in de 
kist is opgesloten. Verwacht was dat het over de gehele periode afdekken de hoogste rotpercentages zou geven. Dit is niet zo gebleken.

- Bij dichte houten kisten is er weinig verschil in de mate van vochtverlies tussen het direct afdekken van peren of als het afdekken pas plaatsvindt als de cellen een aantal weken later op CA-regime gaan. Effect op rot/schimmel kon niet bepaald worden door te laag infectieniveau.

- De positie van de kisten in de cel blijkt een groot effect op het vochtverlies te hebben. De slappenek-score van een relatief warme positie blijkt in experimenten hoger dan van een relatief koude positie. Het vochtverlies van de peren gedurende bewaring op een warme positie toonde op 1 locatie een verdubbeling ten opzichte van de koude positie. De warme kistpositie liet in 2018-2019 meer vliesverkleuring zien.

Via matrixproeven waarbij kistgewichten bepaald zijn, is geprobeerd meer inzicht te krijgen in hoe de warme/koude posities zich in verschillende cellen verdelen. Dit blijkt niet een vaste verdeling te zijn. Daarom wordt aanbevolen dat bewaarlocaties hier zelf metingen aan doen, om een beter beeld te krijgen per cel waar de plekken zijn die voor het meest vochtverlies zorgen en hoe groot deze plek is.

- Verschillen in vochtverliespercentages met verschillende fustsoorten waren niet sterk. De positie-effecten zijn belangrijker dan het fusttype (Boven, $9^{\text {e }}$ kist op stapel, heeft een lager vochtverlies dan de $7^{\mathrm{e}}$ en $8^{\mathrm{e}}$ op de stapel). Sowieso zitten er flinke variaties in vochtverliezen tussen kisten. Variaties van $\pm 0.5 \%$ tussen kisten van hetzelfde type op dezelfde positie zijn geen uitzondering.

\section{Het meten van vochtverlies van een partij gedurende bewaring}

Het gebruik van gewichtsmetingen over een geheel seizoen is bruikbaar om verschillen in vochtverlies tussen posities in cellen in beeld te brengen. Hiervoor moet (kist)gewicht bij inslag en uitslag bepaald worden. De wens is echter om lopende het seizoen een beeld te krijgen van het gewichtsverlies, zodat in combinatie met de vochtspanning bij oogst de humistatus van het product bepaald kan worden. Hiermee zou het een risico op slappe nek (en/of rot) beter ingeschat en mogelijk bijgestuurd kunnen worden. Er zijn diverse sensoren getest tijdens het project:

- De metingen van een YOU-weegunit (Figuur 17) ter bepaling van het gewichtsverlies gedurende de bewaring, geven enige relatie met de daadwerkelijke metingen maar deze methode kent ook de nodige beperkingen. Zo is de meting niet stabiel en kan alleen over een langere meetperiode een gewichtsverlies bepaald worden, en lijkt dus niet zo geschikt voor het nauwkeurig monitoren van gewichtsverlies in perencellen.

- Meten van de relatieve luchtvochtigheid (RV) in de cel om deze te vertalen naar een humistatus of een gewichtsverlies blijft lastig. In het laatste seizoen is gemeten met draadloze $\mathrm{T}$ en RV sensoren en is de meting praktisch goed en nauwkeurig uit te voeren. Het gelijktijdig registreren van de temperatuur en RV, maakt het mogelijk om de drijvende kracht voor vochtverlies, het dampdrukdeficit, te berekenen. De correlatie tussen dampdrukdeficit, die bepaald wordt op basis van de T- en RV-metingen en vochtverlies is zwak. Het kan zijn dat er een parameter zoals luchtsnelheid vereist is, maar in elk geval zijn er een groter aantal metingen voor nodig. De T- en RV-metingen kunnen wel ingezet worden om aanvullend op de productvoelers te gebruiken voor het nastreven van een zo uniform mogelijk klimaat in de cel. Los van de correlatie met gewichtsverlies kan juist de combinatie van plaatselijke producttemperatuur en RV metingen tot inzicht en optimalere sturing leiden.

- De ultrasone afstandmeter van partner EMS (Figuur 26) lijkt gezien de eerste resultaten een potentiële sensor voor indirecte gewichtsverliesmeting en is in het laatste seizoen ook beproefd onder praktijkomstandigheden. De techniek leent zich voor doorontwikkeling naar een sensorsysteem op kistniveau om zo de ruimtelijke verdeling van vochtverlies in de bewaarcel te kunnen monitoren. De sensor blijkt wel enigszins gevoelig voor het zuurstofniveau, en geeft lagere waarden onder CA dan in lucht. Dit lijkt echter geen bottleneck voor toepassing omdat hiervoor gecorrigeerd kan worden. Verder lijkt de techniek geschikt om sterk te verkleinen en te koppelen (IoT) zodat bijvoorbeeld op verschillende plaatsen in de cel het gewichtsverlies gemonitord kan worden. 


\section{Koelergedrag diverse koelsystemen en koudemiddelen}

EU regelgeving rondom koudemiddelen regulering dwingt af dat steeds meer koelsystemen, dus ook die in de fruitbewaring, moeten overstappen naar systemen met natuurlijke koudemiddelen. Met name voor kleinere bewaarfaciliteiten is het een uitdaging om een veilig, betaalbaar en technisch goed functionerend koelsysteem te ontwikkelen, die het vochtverlies laag en de klimaatverdeling zo gelijkmatig mogelijk houdt. Binnen Humistatus zijn metingen uitgevoerd om de invloed van het koelsysteem en het koudemiddel op het gedrag van de koeler tijdens korte, krachtige koelacties inzichtelijk te krijgen. De volgende resultaten zijn gerealiseerd:

- Een glycolsysteem maakt minder snelle en minder krachtige koelacties dan een ammoniakpompsysteem. Het geteste $\mathrm{CO}_{2}$-koelsysteem (in een lege testcel) komt dicht in de buurt van een ammoniakpompsysteem, maar gaf een afwijkend koeleffect aan het einde van de koelactie. Of dit veroorzaakt wordt door de eigenschappen van $\mathrm{CO}_{2}$ zelf en/of de uitvoering van de verdamper of systeem, kan op basis van deze meting niet bepaald worden. Daarvoor zijn meer metingen nodig, liefst in een praktijkcel vol met peren. Van de twee DX-systemen was de meting met R404a niet stabiel en niet krachtig. Dit had ook herkend kunnen worden aan het niet stabiele temperatuurverloop van de blokvoeler. De $\mathrm{CO}_{2} \mathrm{DX}$-koeler functioneerde goed maar was een dubbeluitblazende koeler in een transportruimte. Er kan daarom geen uitspraak gedaan worden of een $\mathrm{CO}_{2} \mathrm{DX}$ systeem ook geschikt is voor korte krachtige koelacties. Koelacties van DX systemen zijn niet vanzelfsprekend stabiel en krachtig.

- De gebruikte meetmethode met een IR-camera voor het meten van de absolute temperatuur, geeft goed en duidelijk de temperatuurveranderingen weer, ondanks de beperkte nauwkeurigheid. Vaste stabiele oververhitting van een circuit is lastiger waar te nemen dan een schommeling van de temperatuur door instabiel gedrag. IR-opnames van de zijkant van een koeler geven meer informatie dan van de voorzijde. Het zou dus mooi zijn, als ondanks de vaak beperkte ruimte tussen koeler en de wand, er toch opnames vanaf de zijkant gemaakt zouden kunnen worden.

- De resultaten van het meten van circuittemperaturen met temperatuurvoelers (in dit geval thermokoppels) op de circuits vallen tegen in nauwkeurigheid. Vraag is in hoeverre dit daadwerkelijk verbetert als er speciale nauwkeurige en thermisch geïsoleerde voelers op de buizen worden ontwikkeld.

- Voor een representatieve meting, waarbij het resultaat niet beïnvloed wordt door andere omstandigheden, wordt geadviseerd om metingen te doen van een koelactie in een volle koelcel die automatisch gestart wordt vanuit de estafette-regeling. 


\section{Introductie algemeen}

\subsection{Aanleiding en doel}

Vochtgerelateerde problemen bij versproducten, zoals schimmel en fysiologisch bederf, leiden tot waarde- en gewichtsverlies. Opvallend is dat deze problemen sterk partijspecifiek optreden. Sprekend zijn de kwaliteitsproblemen bij een lange bewaring van appels en peren. Ook bij andere producten in kortere ketens, denk hierbij aan trostomaten, leidt vochtgerelateerd bederf (kroonschimmel) in de keten tot aanzienlijke verliezen. Het PPS-project Humistatus heeft als overkoepelend doel om minder verliezen in de keten te realiseren door een betere (voorspelbare) kwaliteit, alsmede energiebesparing tijdens de bewaring. Daarbij wordt gezocht naar manieren om partijspecifiek vochtverlies en vochtgerelateerde problemen beter voorspelbaar en beheersbaar te maken. De focus binnen het project ligt op peren en trostomaten.

Aan het begin van het project is gekozen om met 2 werkgroepen te werken: Werkgroep Peer en Werkgroep Tomaat. Dit rapport beschrijft resultaten van de Werkgroep Peer. Het bouwt voort op de resultaten uit de eerste 2 seizoenen onderzoek (2017-2019) ${ }^{2}$ en toont de onderzoeksresultaten van het laatste bewaarseizoen (2019-2020). De samenvatting is geüpdatet, de inleiding is grotendeels overgenomen en de resultaten van het laatste seizoen zijn toegevoegd, evenals de eindconclusies. Het onderzoek is onafhankelijk uitgevoerd door onderzoekers van Wageningen Food \& Biobased Research en Wageningen Plant Research (Randwijk).

\subsection{Globale aanpak project}

In dit publiek-private samenwerkingsproject (PPS), publiek, met als penvoerder de KNVvK (Koninklijke Nederlandse Vereniging voor Koude) werkt Wageningen University \& Research samen met een groot aantal partijen uit verschillende sectoren :

- Technieksector (koudetechniek, sensortechniek, verpakkingen)

- Hardfruitsector (teelt, bewaring, handel)

- Tomatensector (veredeling, teelt, handel)

Het project wordt publiek gefinancierd door het Ministerie van LNV vanuit de Topsector Tuinbouw \& Uitgangsmaterialen, De private financiering wordt binnen de werkgroep peer verzorgt door de volgende bedrijven: B\&B Humidification BV, EMS, Fruitconsult, FruVo BV, Gefi-Fruit Geerts, Koelcentrum Zederik BV, NedCool, Koelhuis WFO, Kelvion, KNVvK, Koelhuis Houten, Boxpall Benelux, Proku, Pedak, VDH, The Greenery, Van Kempen Koudetechniek, Global Cool, Fruitbedrijf Cornelissen, Van Kessel Fruit, VOS technics, Van den Brink BV.

Doel van het project is om methoden/meettechnieken te ontwikkelen waarmee de "humistatus" van een vers product gemeten en geanalyseerd wordt om er vervolgens, liefst partijspecifiek, op te kunnen sturen middels aanpassing van condities in de keten. De beoogde resultaten van de werkgroep Peer zijn:

- Een definitie van humistatus en een meetmethode

- Een prototype sensor voor humistatus

- Een protocol voor vooroogst en bewaring/keten om de humistatus te beïnvloeden om vochtgerelateerde problemen tijdens de lange bewaring van peren te voorkomen

- Gebruiksprotocollen en meet- en regelalgoritmes voor het realiseren van een goed celklimaat tijdens bewaring, en ontwerpparameters voor het conditioneringssysteem, leidend tot minder

\footnotetext{
2 Brouwer et al., 2019. Report 1985 "Resultaten experimenten Humistatus 2017-2019. Tussenrapportage Werkgroep Peer" Wageningen Food \& Biobased Research.
} 
vochtgerelateerde problemen en meer energiebesparing. Bijvoorbeeld betreffende

koudemiddel, verdamper, inkoelsnelheid, luchtcirculatie, verpakking, stapeling, bevochtiging.

- Partijspecifieke oplossingen voor robuuste lange bewaring

- Inzicht in ruimtelijke verdeling van vochtverliesvariaties in bewaarcellen.

Vanwege de aard van de onderzoeksvragen en het consortium is er sterk ingezet op een combinatie van enerzijds laboratoriumexperimenten, waarbij op peerniveau gewerkt wordt aan meer begrip van de fysiologie van de peer en het kunnen meten van de humistatus van een peer, en anderzijds experimenten in de praktijk om de extra factoren waar de praktijk mee te maken heeft (teeltcondities, celposities, kisten, verschillende koelsystemen, bevochtiging etc.), op een praktijkconforme manier mee te kunnen nemen in het onderzoek (Figuur 1).

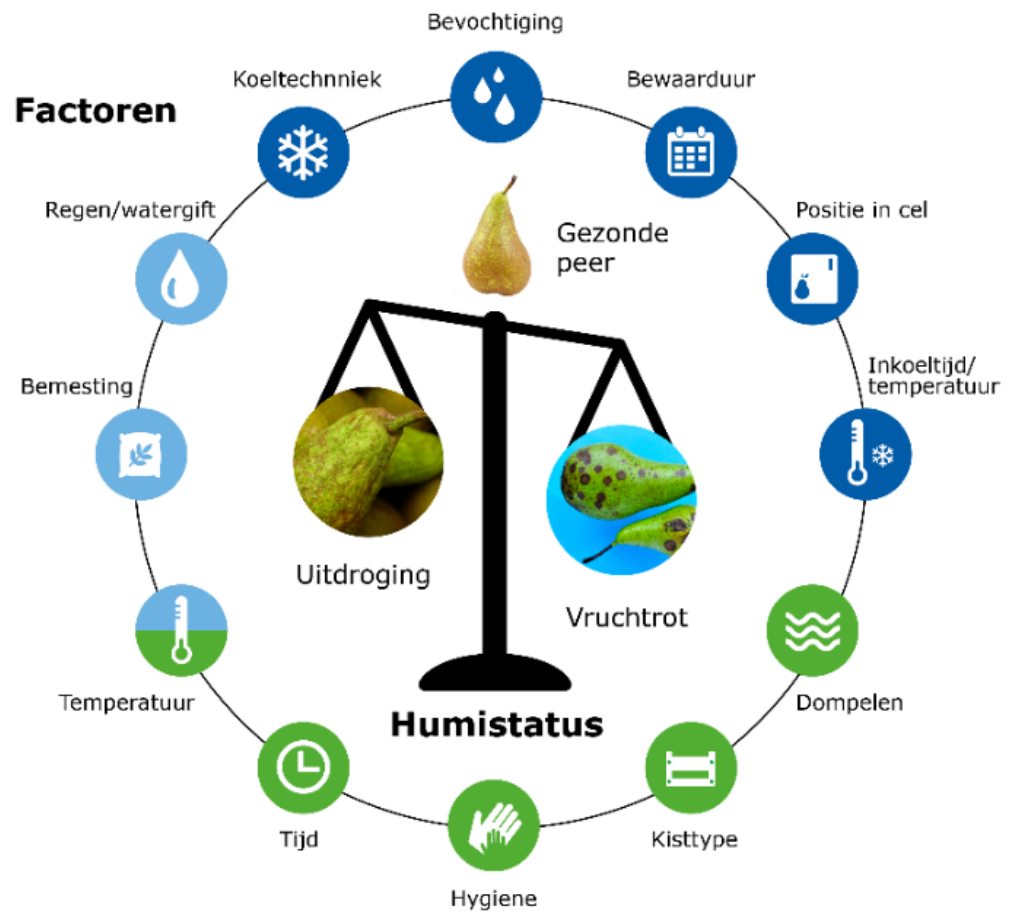

Figuur 1: Visualisatie van verschillende factoren die in het onderzocht zijn op invloed op humistatus van een partij peren. Lichtblauw = teeltfactoren, groen = factoren bij oogst, donkerblauw = factoren tijdens bewaring.

De nadruk van het onderzoek ligt op het in kaart brengen van vochtgerelateerde eigenschappen van een batch peren in relatie tot niet slap worden tijdens de bewaring. Naast eigenschappen van batch richten we ons ook op de omstandigheden die gegeven de eigenschappen tot een vochtverlies of slappe nek ontwikkeling leidt. Hiermee hebben we de mogelijkheid om een juiste balans te vinden enerzijds in het voorkomen van teveel vochtverlies en anderzijds in teveel vruchtrot. We hebben bewust gekozen om het onderzoek niet sterk te focussen op "rot". Dit "rot"-onderzoek vraagt een andere proefopzet (o.a. grotere volumes, andere sampling, andere sortering, langere bewaring) en neemt risico's met zich mee of er wel (voldoende) infectie optreedt in de proefobjecten vanwege de seizoensafhankelijkheid van het optreden van infecties. Daarom is er gekozen binnen dit project om te focussen op de vochteigenschappen in relatie tot slappe nek en alle aspecten daarom heen. Waar mogelijk zijn rotpercentages in de experimenten wel beoordeeld. 


\subsection{Opbouw rapport}

In Hoofdstuk 2 wordt beschreven welke en op welke manier karakteristieken van de peer gebruikt kunnen worden om bij inslag het risico op slappe nekken tijdens bewaring in te kunnen schatten, o.a. met een model. In Hoofdstuk 3 worden resultaten beschreven van met name experimenten in de praktijk, waarbij de impact van praktische variabelen op vochtgerelateerde problemen onderzocht wordt. Hoofdstuk 4 beschrijft de nieuwe resultaten van het gebruik van sensoren in de praktijk (temperatuur, relatieve luchtvochtigheid en een ultrasoonsensor) als tools om gewichtsverlies tijdens bewaring te kunnen monitoren. Hoofdstuk 5 beschrijft de resultaten van een studie waarbij diverse koelers doorgemeten zijn op werking van de koelactie. Afsluitend zijn in Hoofdstuk 6 Conclusies en aanbevelingen beschreven. 


\section{Definitie en ontwikkeling meetmethode humistatus}

\section{$2.1 \quad$ Introductie}

Uitgangspunt bij aanvang van dit project was het idee dat 1) de vochtstatus bij inslag, 2) de gevoeligheid voor uitdroging, én 3) de (lokale) condities na oogst/in de bewaarcel samen bepalend zijn voor de kans om slappe nekken te ontwikkelen. Daarnaast zal deze 'humistatus' van een peer of partij peren meetbaar moeten zijn.

We zijn in dit project op zoek gegaan naar factoren of biomarkers die gerelateerd zijn aan de humistatus en die bijvoorbeeld vochtgerelateerde afwijkingen in de perenbewaring kunnen voorspellen. Hiermee kunnen vervolgens condities tijdens de bewaring afgestemd worden om de humistatus van de peren dusdanig te sturen met het doel de afwijkingen te voorkomen. Deze afwijkingen omvatten schimmel of fysiologisch bederf en waardeverlies door onnodig vochtverlies. Schimmelgroei ontstaat vooral bij hoge luchtvochtigheden in de bewaring, terwijl fysiologisch bederf en waardeverlies gerelateerd zijn aan vochtverlies vanuit het product, wat vooral optreedt bij lagere luchtvochtigheden in de bewaring. Opvallend is dat deze problemen sterk partijspecifiek optreden, bij dezelfde opslagcondities en in sommige gevallen ook bij dezelfde gewichtsverliezen. Dit geeft aan dat er bepaalde factoren zijn die onafhankelijk van gewichtsverlies invloed uitoefenen en die beïnvloed worden door condities tijdens de teelt. Om deze factoren te identificeren is in eerste instantie dieper ingegaan op de fysiologie van de peer.

De 'Conference' peer is een vrucht met een karakteristieke vorm; een ronde buik aan de kroonzijde van de vrucht, getopt door schouders en een nek aan de steel-zijde. Doorgesneden over de kroonsteel-as zijn xyleemvaten zichtbaar vanaf de steel naar een klokhuis, welke zich midden in de buik bevindt. Het klokhuis van een normaal ontwikkelde vrucht bestaat uit vruchtvliezen en zaad(beginselen). Om het klokhuis heen, tot aan de huid bevindt zich het vruchtvlees van de peer, ook wel de binnenste cortex genaamd (Nguyen et al., 2004; Brouwer et al., 2019). Om deze binnenste cortex heen bevindt zich de buitenste cortex, welke bestaat uit de buitenste cellagen van het vruchtvlees en de huid van de peer. Tenslotte wordt de huid beschermd door een waslaag, de cuticula (Lara et al., 2014).

Het is bekend dat kleine vruchten gemakkelijker vocht verliezen dan grote, vanwege de grotere oppervlakte/inhoud ratio van kleine vruchten (Geijn et al., 2006).

De schil van 'Conference' peer bevat dikwijls ook regio's met brons of bronzigheid. Deze bronzigheid ontstaat aan de boom door nachtvorst en tijdens relatief snelle strekkingsgroei van de peer op plaatsen waar scheurtjes in de cuticula ontstaan (Wertheim, 1990) (Scharwies et al., 2014). Op deze plaatsen wordt kurkweefsel gevormd, dat in theorie flexibeler en minder doorlaatbaar is voor water (Konarska, 2013). Naast grootte en bronzigheid heeft ook de vorm van de peer een belangrijke invloed op het waterverlies; peren met een relatief langere en slankere hals verliezen relatief meer water (Nguyen et al., 2006). Dit waterverlies kan zich uiten in het fenomeen 'slappe nek', waarbij de nek van de peer buigbaar wordt en wat als een kwaliteitsprobleem wordt ervaren.

Vocht in de peer bevindt zich met name in de binnenste en buitenste cortex weefsels. Terwijl de binnenste cortex relatief makkelijk water doorlaat, zijn de buitenste cortex en de cuticula respectievelijk 55 en 550 keer betere barrières om waterverlies tegen te gaan (Nguyen et al., 2004; Nguyen et al., 2004; Nguyen et al., 2006; Nguyen et al., 2007). Met andere woorden zou de peer kunnen worden gezien als een zakje om een spons verzadigd met water, waarbij het zakje de uitdrogingssnelheid reguleert en het watervasthoudend vermogen van de spons wordt bepaald door de hoeveelheid opgeloste stoffen.

Om na te gaan welke factoren concreet bijdragen aan vochtverlies en slappe nek is in de afgelopen 4 jaar een grote verscheidenheid aan meetmethodes getoetst op peren vanuit zowel gerichte teelt en 
verschillende partijen uit de praktijk. De data uit deze toetsen is vervolgens gebruikt om inzicht te krijgen in de fysiologische afwijkingen "slappe nek" en "vochtverlies" (Brouwer et al., 2019). Dit inzicht suggereerde dat brons, maat en droge stof gehalte bijdragen aan "slappe nek". Echter, de peren onderliggend aan dit inzicht kwamen van slechts één herkomst. Het doel in dit laatste projectjaar was om het verworven inzicht om te zetten naar een concreet model, welke op basis van inslaggegevens een relatieve gevoeligheid aan zou kunnen geven voor "slappe nek" en "vochtverlies". Hiertoe zijn van 12 herkomsten, met verschillende combinaties van brons, maat en prestatie-historie, peren gemeten bij inslag, opgeslagen voor 8 maanden onder praktijkcondities en zijn bij uitslag vochtverlies en slappe nek bepaald.

\subsection{Materiaal en methoden}

\section{Vruchtmateriaal en bewaring}

Peren (Pyrus communis L. cv. Conference) werden vlak na de oogst (2019) verkregen van 11 verschillende herkomsten uit Nederland, waarbij 1 herkomst twee teeltbehandelingen leverde (Tabel 1). Deze herkomsten waren geselecteerd op basis van locatie, grondsoort, grootte, bronzigheid, vorm en ervaring met peren van deze locaties om verschillende peerkarakteristieken te verkrijgen met betrekking tot uitdroging en slappe nek. De helft van de verkregen peren werd geanalyseerd op kleur, vorm, bronzigheid, gewicht, hardheid en droge stof gehalte. De andere helft werd, in blauwe middelhoge EPS kratten gemixt gestapeld op een pallet en opgeslagen gedurende29 weken (8 maanden) onder 'Controlled Atmosphere' (CA) condities $\left(0.7 \% \mathrm{CO}_{2}, 3 \% \mathrm{O}_{2}\right.$ at $-0.5^{\circ} \mathrm{C}$ en $>9 \%$ relatieve luchtvochtigheid). Hierop volgend zijn de peren voor analyse in lage EPS kratten met inlegvellen gelegd en geanalyseerd. Om verdere uitdroging te bevorderen zijn de peren vervolgens nog 2 weken opgeslagen in open kratten bij $0.5^{\circ} \mathrm{C}$ en $\sim 87 \%$ relatieve luchtvochtigheid.

Tabel 1: Overzicht herkomsten en typering

\begin{tabular}{|c|c|c|c|c|c|c|}
\hline Herkomst & Bodemtype & Grootte & Brons & Vorm & Gevoeligheid vochtverlies (uit ervaring) & Other factors \\
\hline C & $\begin{array}{c}\text { Losse grond } \\
\text { Rivierklei / zand mix }\end{array}$ & $\begin{array}{l}\text { Klein } \\
\text { Groot }\end{array}$ & $\begin{array}{l}\text { Variabel } \\
\text { Gemiddeld }\end{array}$ & $\begin{array}{l}\text { Variabel } \\
\text { Variabel }\end{array}$ & $\begin{array}{l}\text { Bovengemiddeld } \\
\text { Laag }\end{array}$ & Korte bewaring \\
\hline $\begin{array}{l}\text { G } \\
\text { H }\end{array}$ & $\begin{array}{c}\text { Rivierklei } \\
\text { Zeeklei }\end{array}$ & $\begin{array}{l}\text { Gemiddeld } \\
\text { Erg klein }\end{array}$ & $\begin{array}{l}\text { Laag } \\
\text { Hoog }\end{array}$ & $\begin{array}{l}\text { Uniform } \\
\text { Rond, spitse nek }\end{array}$ & $\begin{array}{l}\text { Laag } \\
\text { Hoog }\end{array}$ & - \\
\hline I & $\begin{array}{l}\text { Zeeklei } \\
\text { Rivierklei }\end{array}$ & $\begin{array}{l}\text { Gemiddeld } \\
\text { Groot }\end{array}$ & $\begin{array}{c}\text { Gemiddeld } \\
\text { Laag }\end{array}$ & $\begin{array}{l}\text { Variabel } \\
\text { Uniform }\end{array}$ & $\begin{array}{l}\text { Gemiddeld } \\
\text { Laag }\end{array}$ & Wind-damage \\
\hline
\end{tabular}

Gewicht en vochtverlies

Gewicht van individuele peren en kratten met peren is gemeten met behulp van de elektronische balansen MS6002TS en XS10001L (Mettler-Toledo GmbH, Giessen, Duitsland), respectievelijk. Gewichten van kratten zijn gemeten bij inslag, na 5 weken en na 19 weken om vochtverlies te bepalen.

Vochtverlies is bepaald op basis van gewichtsverlies, met de aanname dat het grootste deel van dit verlies uit vocht (water) zal bestaan.

Kleur, brons en vormfactoren

Achtergrondkleur van de peren is bepaald met behulp van beeldanalyse. Hiervoor zijn foto's gemaakt met een RGB-camera (MAKO G-192C POE, Allied Vision, Stadtroda, Duitsland) in een LED-lichtkast (ontworpen door WFBR en gebouwd door IPSS Engineering, Wageningen, Nederland). The RGB-foto's werden gekalibreerd met behulp van een 24-vlaks kleurenkaart (Color checker classic, X-rite Europe $\mathrm{GmbH}$, Regensdorf, Zwitserland). Beeldanalyse werd gedaan met behulp van een multi-treshold kleuren beeld-segmentatie in de HSV kleurenruimte (in-house software tool ontwikkeld binnen WFBR, Wageningen, Nederland) om de achtergrondkleur van de peren uit te lichten en Hue kleurwaarden hiervan te bepalen. Beeldanalyse is ook gebruikt om de hoeveelheid brons op en vormfactoren van de peren te kwantificeren. Gekwantificeerde Vormfactoren zijn Strekkingsfactor en Oppervlakte ten opzichte van Convex (Figuur 2). 


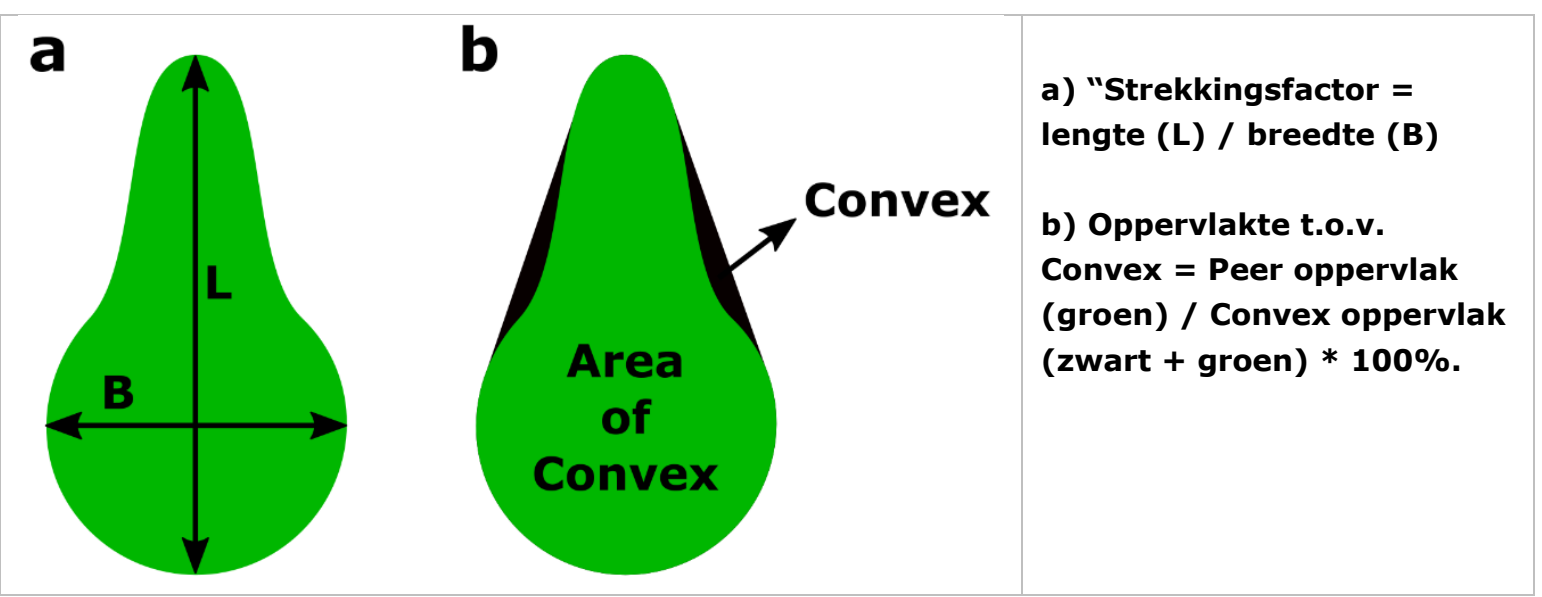

Figuur 2: Toelichting bij vormfactoren "Strekkingsfactor" en "Oppervlakte t.o.v. Convex" zoals bepaald op basis van foto-analyse.

\section{Slappe nek}

Slappe nek scores zijn bepaald door de peer met de buik in de vingers te nemen en met de duim een lichte druk uit te oefenen op de hals. De zijde van de hals aan de andere kant van de duim werd vervolgens beoordeeld aan de hand van een slappe-nek-score tabel (Geijn et al., 2006) : 0, geen rimpels, ook niet bij lichte poging tot buigen; 1, rimpels bij lichte poging tot buigen; 2, rimpels zonder buigen moeilijk zichtbaar van dichtbij; 3, rimpels zichtbaar; 4, diepe rimpels, duidelijk zichtbaar. Voor deze proef zijn de scores per peer onafhankelijk bepaald door twee experts. Het gemiddelde van deze twee scores leverde de slappe nek score per peer.

\section{Hardheid}

De hardheid van de peren is bepaald op de buik van de peer, na het verwijderen van een stukje schil met een dunschiller, met behulp van een Fruit Texture Analyzer (Güss Manufacturing Ltd, Strand, Zuid-Afrika) met een $8 \mathrm{~mm}$ diameter $\left(0.5 \mathrm{~cm}^{2}\right)$ plunjer. De genoteerde waarde $(\mathrm{in} \mathrm{kg})$ is de maximum waarde na het $8.9 \mathrm{~mm}$ doordringen van de plunjer in het vruchtvlees van de peer met een snelheid van $10 \mathrm{~mm} / \mathrm{s}$.

Droge stof

Vanuit de buik van de peer werd een $1 \mathrm{~cm}$ dikke schijf gesneden, waarna een kwart van de schijf werd gebruikt voor bepaling van drooggewicht.

Voor de droge stofbepaling werden de stukjes peer in vooraf gewogen aluminium schaaltjes gelegd, gewogen en bij $80^{\circ} \mathrm{C}$ geplaatst in een droogstoof (FP 720, Binder GmbH, Tuttlingen, Duitsland). $\mathrm{Na} 4$ dagen zijn de bakjes wederom gewogen en is het relatieve drooggewicht bepaald.

Data analyse en modellering

Data verwerking en het maken van grafieken werd vooral gedaan met Microsoft Excel. Multivariaat analyse en multiple lineaire regressie modellen werden gedaan met Unscrambler X 10.5 (CAMO Software, Oslo, Noorwegen). Modellering via logistische regressie is gedaan in $\mathrm{R}$.

\subsection{Resultaten en discussie}

In seizoen 2018-2019 is het inzicht verkregen dat een hoog droge stof gehalte, een hoog percentage brons, en een kleine maat bijdragen aan een hogere slappe nek score. Om dit vervolgens om te zetten naar een concreet model is er besloten om twee strategieën te gebruiken. Ten eerste zijn modellen, gemaakt op basis van de 2018-2019 data, gevalideerd met behulp van een nieuwe dataset. Ten tweede is er op basis van deze nieuwe dataset een nieuw model gemaakt, welke vervolgens is getest op de data van voorgaande seizoenen.

De nieuwe dataset werd verkregen door partijen peren te selecteren van 12 herkomsten. De selectie gebeurde op basis van de grondsoort waarop werd geteeld, samen met verschillende combinaties van brons, maat en prestatie-historie (Tabel 1, Figuur 3). Na selectie werden monsters genomen en werd 
van alle partijen een deel naar WFBR vervoerd voor inslag-analyse en een deel voor 8 maanden opgeslagen onder commerciële condities. Na opslag werden ook deze peren geanalyseerd en beoordeeld op vochtverlies en slappe nek.

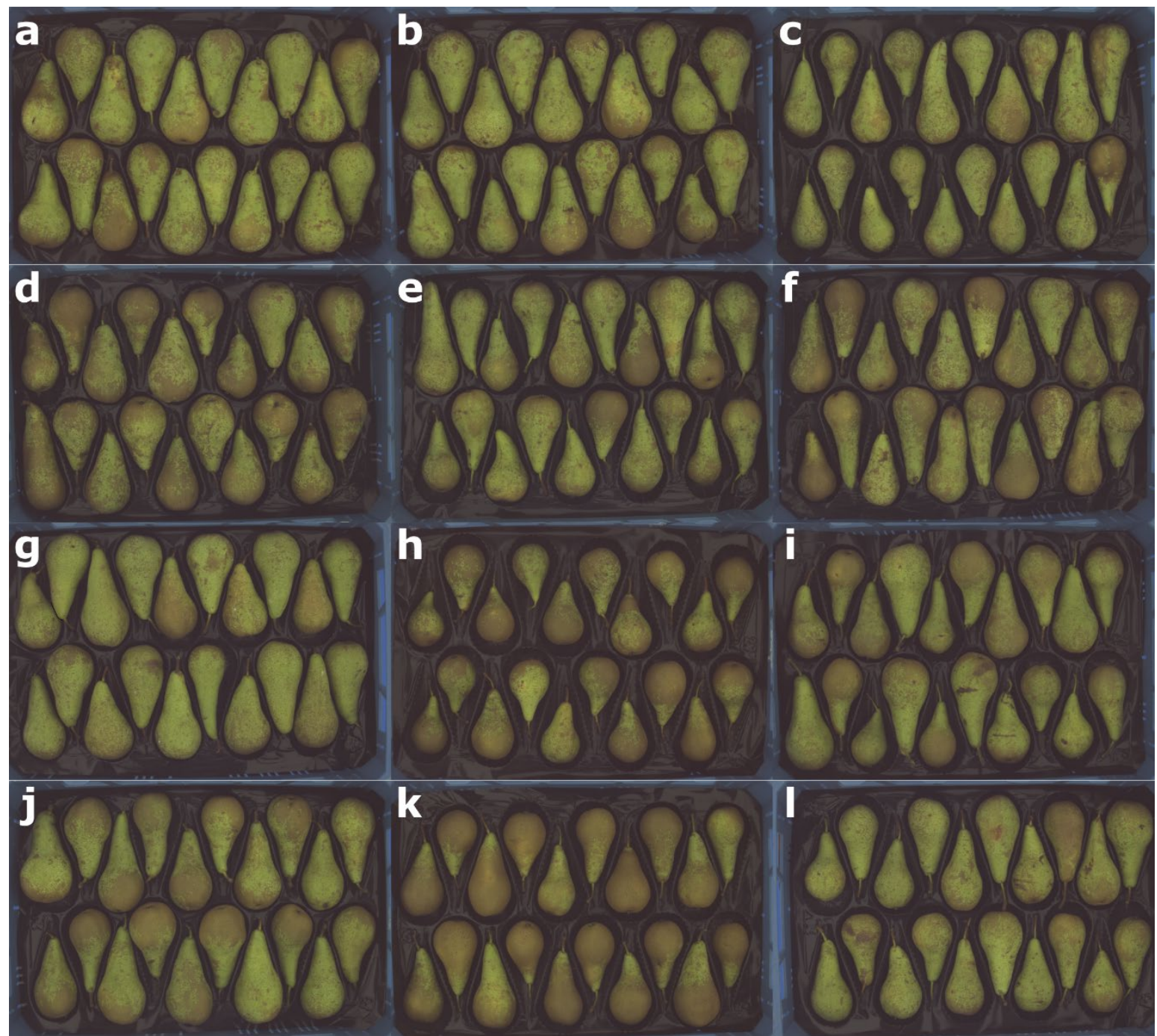

Figuur 3: Karakteristieke peren van de verschillende herkomsten A-L.

\subsubsection{Validatie modellen slappe nek seizoen 2018-2019}

De inzichten van seizoen 2018-2019 voor slappe nek waren gebaseerd op een multiple lineaire regressie gedaan op basis van gemiddelden van inslaggegevens. Hierbij kwamen gewicht, droge stof gehalte en percentage oppervlakte brons naar voren als belangrijke factoren. Een nieuwe analyse, gedaan op de onderliggende data van de individuele peren, wederom via multiple lineaire regressie, resulteerde in een concreet model met brons en droge stof als belangrijkste factoren. Echter, daar de individuele peren voornamelijk groot waren en uit andere experimenten maat ook belangrijk leek, is er ook een regressiemodel gemaakt met inbegrip van de factor gewicht. Om de (relatieve) waarde van deze modellen te toetsen zijn ze gevalideerd met behulp van de dataset van seizoen 2019-2020. Hiertoe zijn voor de 12 herkomsten bij inslag droge stof, gewicht en brons bepaald (Figuur 4a-c) en zijn na 29 weken bewaring de slappe nek scores bepaald (Figuur 4d). Gezien de slappe nek score na 29 weken bewaring relatief laag was, zijn de peren tevens een extra 2 weken opgeslagen onder sterker drogende omstandigheden (31 weken opslag totaal). 


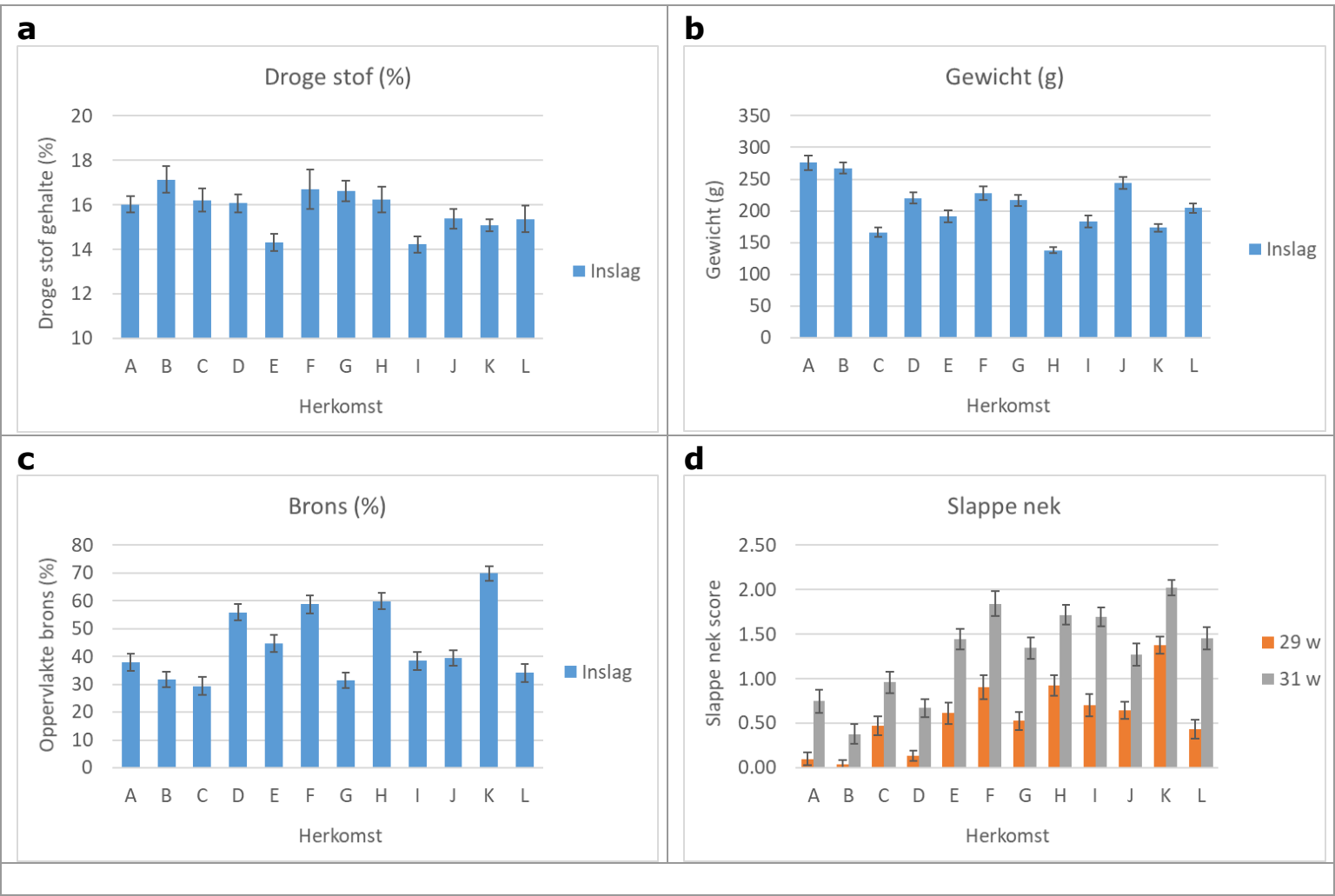

Figuur 4: Fysiologische karakterisatie van Conference peren van de verschillende herkomsten A-L. Bepaald bij inslag zijn droge stof (a), gewicht (b), het percentage oppervlak brons (c) en bij uitslag slappe nek (d). Slappe nek is bepaald na 29 weken opslag en na een extra 2 weken onder sterker drogende omstandigheden. Data zijn gemiddelden $\pm 95 \% C I, n_{d r o g e ~ s t o f ~}=20$ en $n_{\text {gewicht, brons en slappe nek }}=100$.

Op basis van de inslagwaarden zijn de modellen getoetst ten opzichte van de waarden na 29 en 31 weken opslag (Tabel 2). Deze toetsing is gedaan op een relatieve manier, dat wil zeggen dat gekeken is of relatief lage, middelgrote en hoge voorspellingen overeen kwamen met de relatief lage, middelgrote en hoge uitkomsten van slappe nek. Het model op basis van alleen droge stof en brons (DB) suggereerde dat herkomsten $D, F, H$ en $\mathrm{K}$ een hoge en $\mathrm{A}, \mathrm{B}, \mathrm{G}$ en J een middelhoge slappe nek score zouden hebben na bewaring. Als we dit vergelijken met de eigenlijke scores na 29 weken opslag, dan zien we dat dit correct lijkt te zijn voor herkomsten $F, H$, J en K. Echter, A, B en D werden beduidend hoger en $E$, I en $L$ lager voorspeld dan de uiteindelijke score. Inbegrip van gewicht, in model DGB, gaf relatief verbetering, al werd herkomst $D$ nog steeds sterk overschat en werden herkomsten $E, G$, I en J relatief onderschat. Dit suggereert dat het model ofwel aangepast moet worden aan de grotere range aan droge stof, gewicht en brons tussen de herkomsten ofwel verder aangepast moet worden door andere factoren toe te voegen. 
Tabel 2: Voorspellende en uiteindelijke scores voor slappe nek na opslag van de verschillende herkomsten. Voorspellende scores zijn gemaakt op basis van twee modellen; met de factoren droge stof en brons (DB) en droge stof, gewicht en brons (DGB). Uiteindelijke scores zijn bepaald na 29 weken opslag (29w) en na 2 extra weken uitdrogings-bevorderende opslag (31 w). Data van opslag zijn gemiddelden $(n=100)$. Voor relatief vergelijk van model en opslagwaarden is een conditionele formattering toegepast van laagste (wit) naar hoogste waarde (rood).

\begin{tabular}{|c|cc|cc|}
\hline \multirow{2}{*}{ Herkomst } & \multicolumn{3}{|c|}{ Model } & \multicolumn{2}{|c|}{ Opslag } \\
& DB & DGB & 29 w & 31 w \\
\hline A & 1.74 & 1.47 & 0.10 & 0.75 \\
B & 1.77 & 1.50 & 0.04 & 0.38 \\
\hline C & 1.67 & 1.57 & 0.47 & 0.96 \\
D & 1.93 & 1.74 & 0.14 & 0.67 \\
\hline E & 1.67 & 1.54 & 0.62 & 1.44 \\
F & 2.01 & 1.80 & 0.90 & 1.84 \\
\hline G & 1.73 & 1.54 & 0.53 & 1.35 \\
H & 1.98 & 1.93 & 0.93 & 1.72 \\
\hline I & 1.60 & 1.49 & 0.71 & 1.70 \\
J & 1.70 & 1.49 & 0.65 & 1.27 \\
\hline K & 1.99 & 1.88 & 1.38 & 2.03 \\
\hline L & 1.65 & 1.49 & 0.44 & 1.46 \\
\hline
\end{tabular}

\subsubsection{Modellering op basis van data seizoen 2019-2020}

Om een beter model te genereren is de dataset van 2019-2020 na bewaring gebruikt, welke grotere variabiliteit aan verschillende factoren bevat (Tabel 1). Op de herkomstgemiddelden van deze dataset, waaraan tevens het vochtverlies na 5 weken was toegevoegd, is multiple lineaire regressie uitgevoerd. Hierbij is aangenomen dat ${ }^{\circ}$ Brix, gewicht, brons $\%$, droge stof $\%$, Strekkingsfactor en Oppervlakte \% ten opzichte van convex hetzelfde zijn gebleven tijdens bewaring of zich grotendeels als zodanig verhouden. Strekkingsfactor staat hierbij voor de lengte van de peer gedeeld door de breedte (Figuur 2a). Oppervlakte \% ten opzichte van convex is een maat voor de slankheid van de hals ten opzichte van de buik, waarbij een score van $80 \%$ een slanke nek ten opzichte van de buik heeft en $100 \%$ een fles peer benaderd (Figuur 2 b). Dit resulteerde in een model gebaseerd op brons (\%), gewicht ( $\mathrm{g}$ ) en de oppervlakte ten opzichte van convex (\%), met een $\mathrm{R}^{2} \mathrm{val}$, de $\mathrm{R}^{2}$ van de validatie set in de analyse, van 0.50. Vervanging van gewicht door "object vruchtoppervlak", welke bepaald kan worden met dezelfde meetmethode als brons en oppervlakte t.o.v. convex, resulteerde in een nieuw model (BCO model), welke een $\mathrm{R}^{2}$ val had van 0.49. Dit geeft aan dat model met object oppervlak bijna even goed is als het model met gewicht (BCG model), met als voordeel dat er slechts 1 meetmethode nodig is. De relatieve impact-factoren van de variabelen op slappe nek waren +0.58 voor brons, -0.48 voor oppervlakte ten opzichte van convex en -0.17 voor vruchtoppervlak. Het BCO model is vervolgens gebruikt om een voorspelling te geven op basis van de inslagwaarden van verschillende herkomsten in de experimenten van afgelopen jaren. In Figuur 5 wordt deze voorspelling uitgezet tegen de werkelijke slappe nek score na opslag. 
a

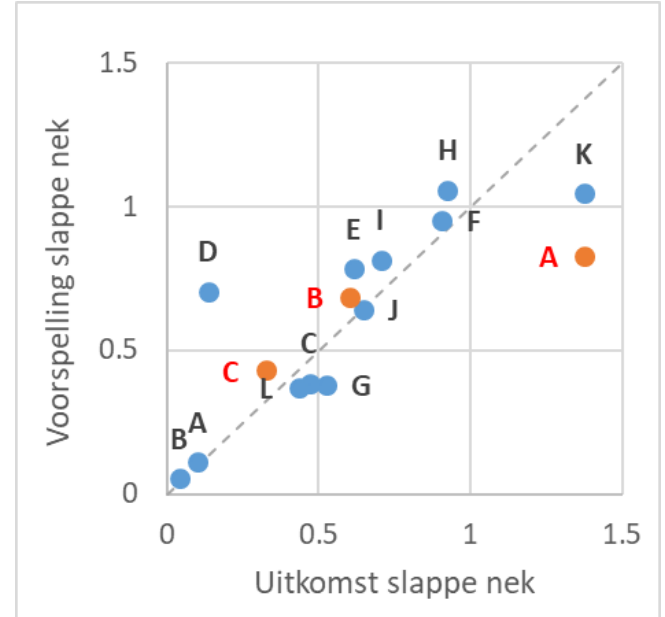

b

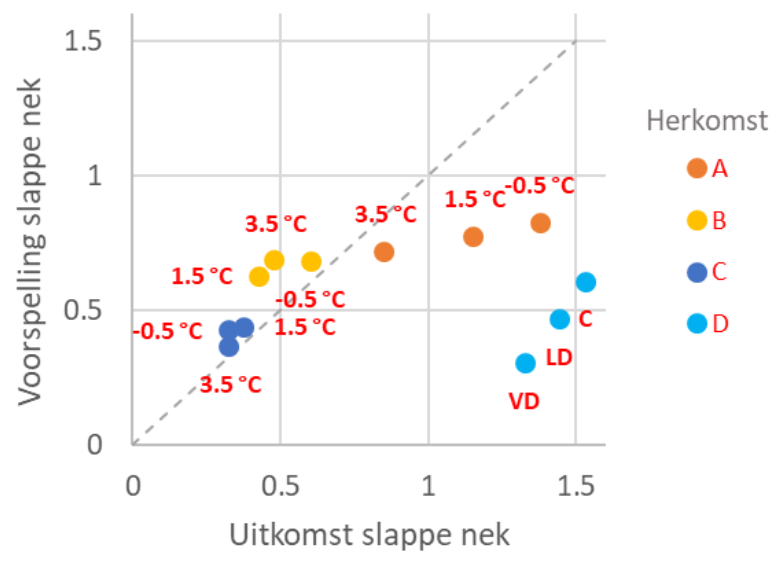

Figuur 5: Voorspelling en uitkomst van slappe nek op basis van inslagdata volgens het BCO model. Voorspellingen zijn vergeleken onder standaard bewaarcondities gestuurd op laag vochtverlies (a) of onder variabele inkoeltemperatuur en variabele watergift tijdens de teelt opgeslagen onder condities van hoog vochtverlies (b). Herkomsten zijn aangeduid met letters, variatie in inkoeltemperatuur is aangegeven in de labels $\left({ }^{\circ} \mathrm{C}\right)$, variatie in watergift bij Herkomst $D$ is aangegeven als Control (C), Vroege droogte (VD) en Late droogte (LD). Seizoen is aangeduid voor 2018-2019 (rood) en 2019-2020 (zwart). De gestippelde lijn geeft de ideale voorspellingslijn weer.

Zoals te zien is in Figuur 5a, liggen de modeluitkomsten (blauwe stippen) redelijk dicht rondom de ideale voorspellingslijn, maar wordt herkomst $D$ flink overschat en herkomst $K$ onderschat (blauwe stippen). Vervolgens werd het model gebruikt om een voorspelling te doen op basis van uitslag-data van drie herkomsten vanuit een inkoelproef in seizoen 2018-2019 welke opgeslagen waren onder dezelfde condities (Figuur 5a, oranje stippen). Dit liet zien dat het model slappe nek redelijk goed voorspelde beneden de 0.70 en dat voor voorspelde waarden boven de 0.70 het model een onderschatting geeft.

Om een beeld te krijgen van hoe het model omgaat met veranderingen in inkoel- en opslagcondities, is er meer data uit seizoen 2018-2019 geanalyseerd met het model (Figuur 5b). Met betrekking tot variabele inkoeltemperatuur was weinig afwijking van de lijn te zien, behalve bij herkomsten $A$ en $D$. Herkomst A had voorspelde slappe nek waarden boven de 0.70 en werd onderschat. Herkomst $D$ bestond uit peren die waren geteeld onder verschillende typen van droogtestress; controle (C), vroeg droog (VD) en laat droog (LD). Uit eerder onderzoek was gebleken dat deze stressen weinig tot geen significant effect hadden op de ontwikkeling van slappe nek. De voorspelde slappe nek waarden werden ingeschat beneden de 0.70 en had na bewaring slappe nek waarden boven de 1.0. Ondanks dat dit een flinke onderschatting is, is de reden hiervoor te vinden in het feit dat deze peren waren opgeslagen onder meer uitdrogende omstandigheden om slappe nek op te wekken. Dit betekent dat het model minder geschikt is voor afwijkende opslagcondities, maar nog steeds goed lijkt te werken voor vergelijking van herkomsten onderling die onder vergelijkbare condities worden opgeslagen.

Om dieper in te gaan op mogelijke andere mogelijke factoren voor het model die overschaduwd worden door de verschillen tussen herkomsten werd per herkomst logistische regressie uitgevoerd op de uitslag-data van individuele peren. Om een grotere range aan slappe nek te verkrijgen zijn de slappe nek scores na 2 extra weken uitdroging gebruikt en omgezet naar binaire waarden. Een slappe nek score van 0-1.5 werd als 0 aangeduid en een score $\geq 2$ als 1 . Bijna alle herkomsten konden op deze manier worden gemodelleerd, behalve herkomsten $B$ en $K$ (Tabel 3). De fractie aan slappe nek bij de herkomsten A-D was tevens relatief laag, waardoor deze modellen een gelimiteerde zeggingskracht hebben. Deze analyse liet zien dat er veel variatie was tussen de herkomsten met betrekking tot de factoren waarmee slappe nek waarden voorspeld werden. Binnen herkomsten leken met name maat (gewicht en objectarea in Tabel 3), vorm (elongation factor en area \% of convex) en vochtverlies over tijd bij te dragen aan slappe nek. 
Tabel 3: Betrokkenheid van factoren bij het optreden van slappe nek in logistische regressie modellen per herkomst. Herkomsten met een lage fractie aan peren met slappe nek 22 zijn geel weergegeven. Data van betrokken factoren zijn weergegeven als p-waarden. Significante betrokkenheid $(p<0.05)$ is rood is weergeven.

\begin{tabular}{|c|c|c|c|c|c|c|c|c|c|c|c|c|}
\hline & \multicolumn{12}{|c|}{ Herkomst } \\
\hline & A & B & C & D & E & $\mathbf{F}$ & G & $\mathbf{H}$ & 1 & $\mathrm{~J}$ & $\mathrm{~K}$ & $\mathrm{~L}$ \\
\hline Fractie slappe nek $\geq 2$ - $31 \mathrm{w}$ & 0.07 & 0.02 & 0.13 & 0.02 & 0.34 & 0.59 & 0.27 & 0.48 & 0.50 & 0.29 & 0.79 & 0.34 \\
\hline Gewicht (g) & 0.1910 & 0.1689 & 0.6864 & 0.4375 & 0.1359 & 0.0083 & 0.1980 & 0.0439 & 0.0056 & 0.0006 & 0.4150 & 0.1396 \\
\hline Object area (px) & 0.1989 & 0.9904 & 0.4624 & 0.1921 & 0.0896 & 0.0382 & 0.5534 & 0.0399 & 0.0029 & 0.0076 & 0.4485 & 0.1459 \\
\hline Brons adj (\%) & 0.8915 & 0.7578 & 0.3946 & 0.5781 & 0.8267 & 0.9491 & 0.1271 & 0.8370 & 0.0453 & 0.8754 & 0.6856 & 0.0010 \\
\hline Elongation Factor & 0.9856 & 0.9640 & 0.2383 & 0.0399 & 0.4033 & 0.0213 & 0.3263 & 0.0212 & 0.2611 & 0.0116 & 0.5409 & 0.2800 \\
\hline Area \% of Convex & 0.0104 & 0.5477 & 0.0348 & 0.0119 & 0.9407 & 0.0685 & 0.2380 & 0.0055 & 0.4801 & 0.0103 & 0.3086 & 0.0749 \\
\hline Vochtverlies 29-31w (\%) & 0.6807 & 0.6851 & 0.2944 & 0.5596 & 0.0307 & 0.0639 & 0.0108 & 0.1739 & 0.0393 & 0.0042 & 0.7752 & 0.0046 \\
\hline
\end{tabular}

Als we deze informatie koppelen aan het BCO model, dan kunnen we slappe nek op twee manieren beschrijven:

- $\quad$ Ten eerste kunnen we met het BCO model de gevoeligheid van een herkomst voor slappe nek bepalen op basis van brons, oppervlakte ten opzichte van convex en grootte. Als de voorspelde waarde beneden de 0.70 ligt, dan geeft dit een goede indicatie voor de slappe nek onder standaard opslagcondities. In geval de voorspelde waarde boven de 0.70 ligt, dan is dit waarschijnlijk een onderschatting. In de praktijk maakt dit echter niet uit, daar gemiddelde slappe nek scores van 0.6-0.7 als voorbij het optimale beschouwd worden. Alhoewel dit model goed lijkt te werken op basis van de afgelopen seizoenen, is extra validatie en versterking van het model over meerdere seizoenen sterk aan te raden.

- Ten tweede weten we nu dat slappe nek binnen herkomsten af kan hangen van verschillende factoren, waaronder maat, vorm en de hoeveelheid vocht die is verloren door de peren. Hoeveel elk van deze factoren bijdraagt verschilt per herkomst en is dus lastig in een enkel model te beschrijven. Wel is duidelijk dat hoe meer vocht een peer verliest, hoe groter de score voor slappe nek.

Op basis van deze analyses kunnen we helaas niet zeggen of brons, vorm en maat directe oorzaken zijn voor de vorming van slappe nek. Hiervoor zouden experimenten nodig zijn die zich focussen op de individuele factoren in partijen met verschillende gevoeligheden voor slappe nek. Met behulp van dit model hebben we in ieder geval een belangrijke stap gemaakt in het identificeren van de gevoeligheid van partijen voor slappe nek, wat gericht onderzoek naar de oorzaak mogelijk maakt.

\subsubsection{Voorspelling van vochtverlies}

Aanvankelijk werd verwacht dat verschillen in vochtverlies tussen partijen peren een directe link zou hebben met het optreden van slappe nek. Echter, de modellering van slappe nek liet zien dat andere verschillen tussen herkomsten belangrijker zijn. Dit betekent echter niet dat vochtverlies geen belangrijke factor is in de ontwikkeling van slappe nek. Slappe nek-scores na 2 weken extra opslag bovenop de 29 weken waren in alle gevallen fors hoger, en analyse gaf aan dat de verschillen in deze toename van slappe nek binnen herkomsten mede afhing van vochtverlies. Deze toename in score verschilde ook sterk per herkomst en geen van de slappe nek modellen sloot hier goed bij aan. Dit suggereert dat reductie van vochtverlies wel degelijk van belang kan zijn in het minimaliseren van slappe nek vorming.

In het voorgaande rapport was al naar voren gekomen dat gewichtsverlies na een stress-test of na relatief korte bewaring correleert met het gewichtsverlies na langere bewaring (Brouwer et al., 2019). Om te kijken in hoeverre dit afhangt van de herkomst is van dezelfde peren als in hoofdstuk 2.3.1. van alle herkomsten het gewichtsverlies na 5 en na 29 weken gemeten.

Zoals te zien in Figuur 6, correleerde het vochtverlies na 5 weken in grote lijnen met dat na 29 weken, maar gaf het geen precieze voorspelling. Diverse herkomsten weken, na 29 weken bewaring, af van de correlatielijn op basis van het gewichtsverlies na 5 weken. Een reden hiervoor kan zijn dat er te weinig waarnemingen waren. 

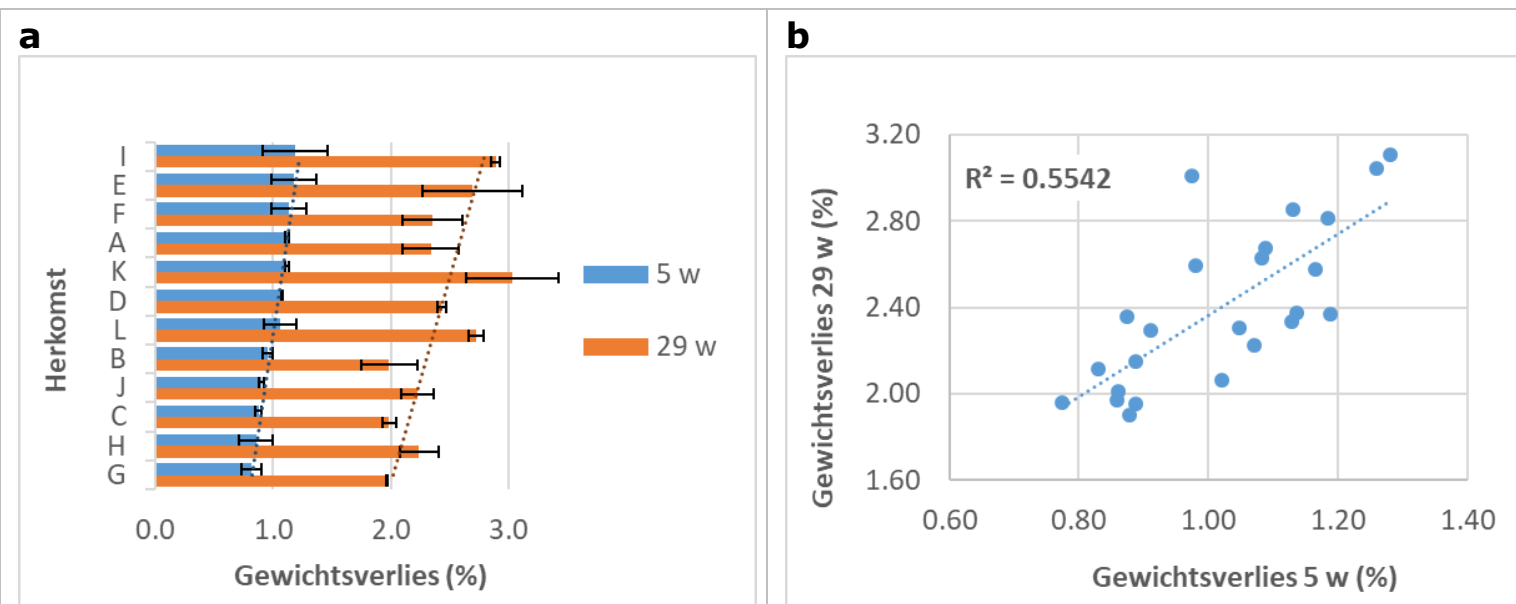

Figuur 6: Gewichtsverlies van peren (cv. 'Conference') na 5 en 29 weken opslag onder RA condities bij $-0.5^{\circ} \mathrm{C}$ (a) en correlatie tussen de twee opslagtijden (b). Gewichtsverliezen van herkomsten zijn gesorteerd van laag naar hoog op basis van hun gewichtsverlies na 5 weken (a). Data zijn gemiddelden $\pm 95 \%$ CI, $n=2$. Data zijn waarnemingen per krat van 60 peren.

Om na te gaan of er met de input vanuit de 12 herkomsten nog andere factoren, die bij inslag te bepalen zijn, relateren aan het uiteindelijke vochtverlies, werd ook hier multivariaat analyse toegepast.

Kruiscorrelatie van de factoren liet naast de correlatie vochtverlies na 29 en 5 weken ( $\left.R^{2}: 0.61\right)$ ook correlaties zien tussen het vochtverlies na 29 weken en Brix (-0.74), het vochtgehalte bij inslag (0.65) en het percentage brons (0.23). Andere analyses, zoals PCA en PLS, lieten een vergelijkbaar beeld zien. Hierop is er besloten een multiple lineaire regressie toe te passen om te zien of combinaties van deze inslagfactoren mogelijk een verbeterd model op zouden leveren. Dit bleek inderdaad het geval te zijn voor de factoren Brix $\left(^{\circ}\right)$ en Brons (\%) in het model:

$$
\text { VV } 29 w(\%)=0.0119 * \text { Brons }(\%)-0.3618 * \text { Brix }+6.50
$$

Dit model suggereert dat Brons positief bijdraagt aan het vochtverlies en dat een hoger gehalte oplosbare suikers ( $\left.{ }^{\circ} \mathrm{Brix}\right)$ dit verlies beperkt. In eerdere jaren van dit project kwam deze relatie niet naar voren, waarschijnlijk omdat de peren in die jaren van één locatie kwamen en de variatie in Brons en ${ }^{\circ}$ Brix relatief klein was. Bovenstaand beschreven model lijkt een stuk nauwkeuriger (Figuur 7) dan de schatting op basis van het vochtverlies na 5 weken Figuur $6 \mathrm{~b}$. Echter, het bovenstaande model is gebaseerd op slechts 12 herkomstgemiddelden van een enkel seizoen. Het zou interessant zijn om de essentie van dit model voor meerdere herkomsten over meerdere seizoenen te volgen. Of concreter gezegd; of dit model het relatieve vochtverlies van partijen op basis van Brix en Brons zou kunnen voorspellen. Deze gevoeligheid voor vochtverlies zou vervolgens gebruikt kunnen worden als inschatting van de waardedaling van een partij door gewichtsverlies en/of vergeleken kunnen worden met de gevoeligheid voor slappe nek. 


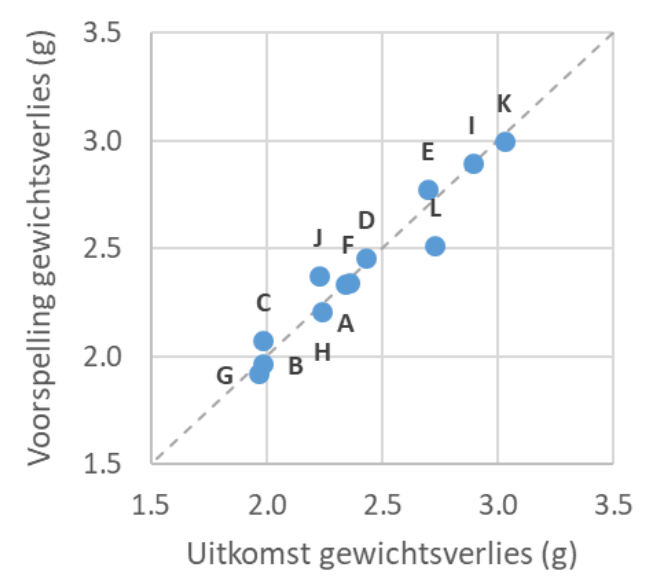

Figuur 7: Voorspelling en uitkomst van vochtverlies op basis van inslagdata volgens het vochtverliesmodel. Voorspellingen zijn vergeleken onder standaard bewaarcondities gestuurd op laag vochtverlies. Herkomsten zijn aangeduid met letters. De gestippelde lijn geeft de ideale voorspellingslijn weer.

\subsection{Conclusie}

Het onderzoek heeft een gevorderd model opgeleverd waarmee de relatieve gevoeligheid van herkomsten op de vorming van slappe nek op basis van brons, vorm en maat bepaald kan worden via een kleurenkast foto-analyse. Verdere uitwerking is aan te raden naar bijvoorbeeld verschillende bewaaromstandigheden. Het zou ook goed zijn om te testen hoe goed het model in praktijk gekoppeld kan worden aan bewaaradvies voor partijen.

Er is ook een eerste model voor relatieve gevoeligheid van herkomsten voor vochtverlies op basis van Brons en Brix. Dit vraagt nog om verdere uitwerking en validatie. 


\section{Invloed (na-)oogstfactoren en bewaarregime op vochtstatus (praktijk)}

\subsection{Introductie}

Op diverse praktijklocaties zijn in 2019-2020, net als in de seizoenen 2017-2018 en 2018-2019 proeven uitgezet, in nauwe samenwerking met de partners. Doel is om ondanks de soms grote impact van niet begrepen praktische variabelen, dicht bij de praktische toepassing, de effecten van de te onderzoeken variabelen op vocht gerelateerde problemen te beoordelen. We hebben ons afgelopen seizoenen op de volgende vragen gericht:

- Wat is de invloed van de periode tussen oogst en bewaring (tijd ongekoeld)?

- Wat is de invloed van de snelheid van inkoelen?

- Welke periode tijdens het bewaren is meest bepalend voor het vochtverlies?

- Hoe groot zijn de verschillen in vochtverlies tussen herkomsten op specifieke posities in de cel?

- Wat is de invloed van het type fust (en behandeling)?

- Hoe is de verdeling van vochtverlies binnen de cel?

In het laatste seizoen, in onderstaande hoofdstuk beschreven, is nogmaals de invloed van het fust type en de variatie in vochtstatus binnen cellen (positie en herkomst) onderzocht. Om het overzicht te behouden is steeds een enkele proef in een paragraaf beschreven met doel, materiaal en methode, resultaten en conclusie.

\subsection{Fusttype en vochtverlies}

\subsubsection{Doel}

Verkennen van effect van fusttype op mate van gewichtsverlies.

\subsubsection{Inleiding en eerdere onderzoekservaringen}

Onderzoek in seizoen 2018-2019 toonde een beperkt verschil aan tussen de verschillende fustsoorten. De positie van de kisten bleek veel belangrijker. De bovenste kisten op de stapel laten stelselmatig een lager vochtverlies zien dan de lager geplaatste kisten. Dit sluit aan bij de bevindingen in de positieproef waarin ook de kisten op de koudste positie het minste vochtverlies laten zien. Het beoordelen van schimmel- en rotontwikkeling na bewaring liet een beperkte rotontwikkeling zien bij zowel de open en dichte plastic kisten. Bij houten kisten wordt wel meer rot gevonden. Extra geplaatste houten kisten met zichtbaar schimmel bij inslag tonen na bewaring de meeste rotontwikkeling op het product. De inschatting is dat het maximale uitvalpercentage door rot in deze proef (behandeling kist met zichtbaar schimmel) onder de 5\% ligt.

\subsubsection{Materiaal en methode}

\section{Seizoen 2019-2020}

Van 1 herkomst zijn 3 fusttypen, te weten hout perenkist (dicht), kunststof dicht en kunststof open gevuld met Conference peren op specifieke posities in een cel (celnr. 79) geplaatst. Per fust type zijn steeds 5 kisten gemeten. We richtten ons specifiek op de gewichtsverliezen van kisttypen en de invloed van positie.

De kisten zijn op specifieke posities in de cel geplaatst met elke type fust (dicht hout, kunststof dicht en kunststof open) en op een eigen rij in breedte van de cel (respectievelijk rij 2, 3 en 4 (van 4). 
Hierbij zijn 3 kisten per type en positie direct op elkaar geplaatst waarbij de bovenste kist steeds de bovenste kist van de stapel was. De kisten zijn bruto gewogen bij inslag en uitslag na 8 maanden bewaring.

\subsubsection{Resultaten}

De gewichtsverliezen, waarbij het houten fust is gecorrigeerd voor vochtopname tijdens bewaring (2.5 kg per kist), verschillen gemiddeld per fusttype, maar deze verschillen worden overschaduwd door een grote variatie binnen het fusttype (Figuur 8).

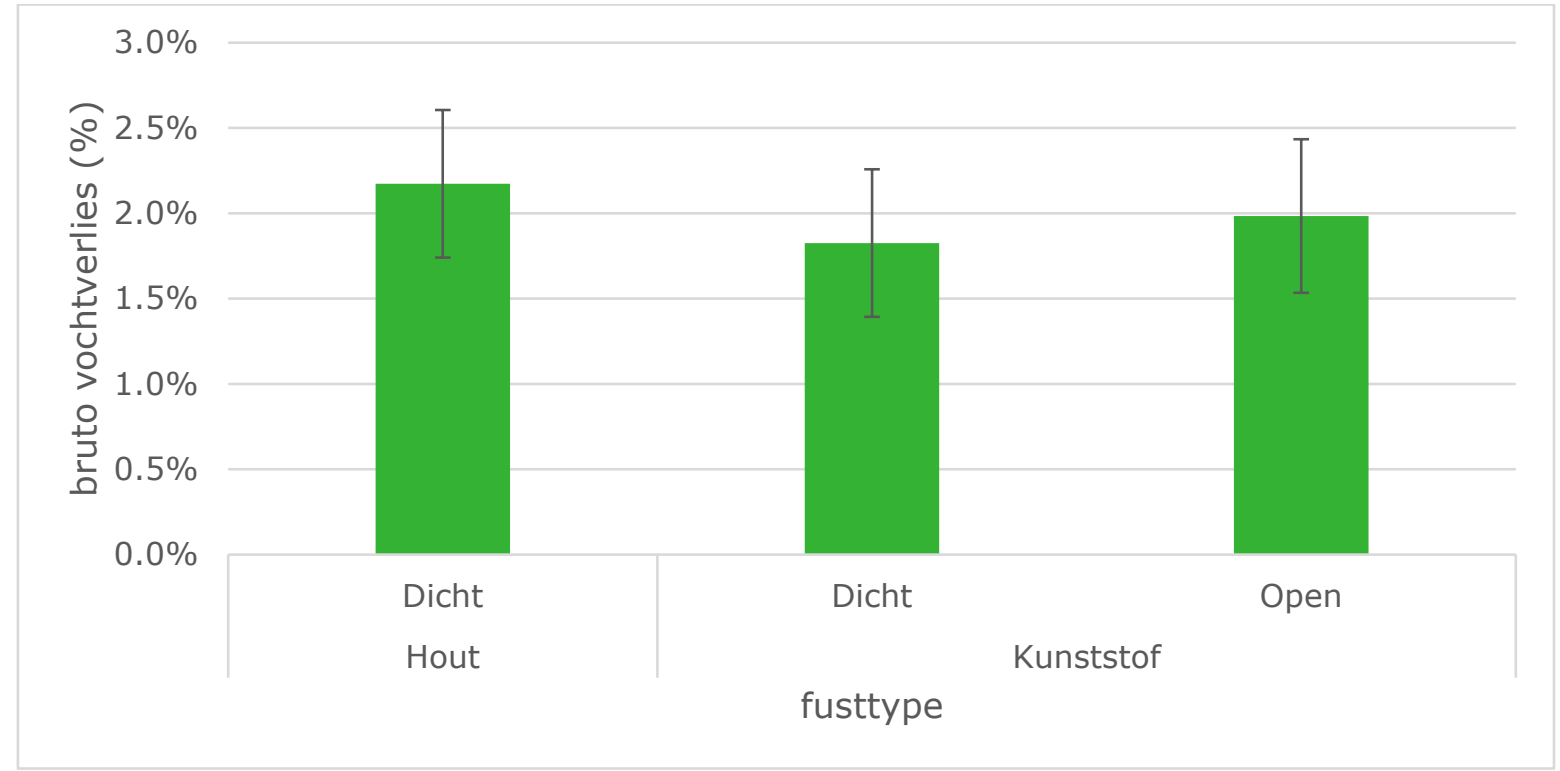

Figuur 8: Invloed van fusttype op percentage gewichtsverlies gedurende 8 maanden. Data zijn gemiddelden \pm standaard deviatie, $n=5$.

De positie van de kist (op stapel) lijkt in deze proef zeker zo belangrijk. In onderstaande Figuur 9 is een gemiddeld lager vochtverlies op de bovenste positie te vinden.

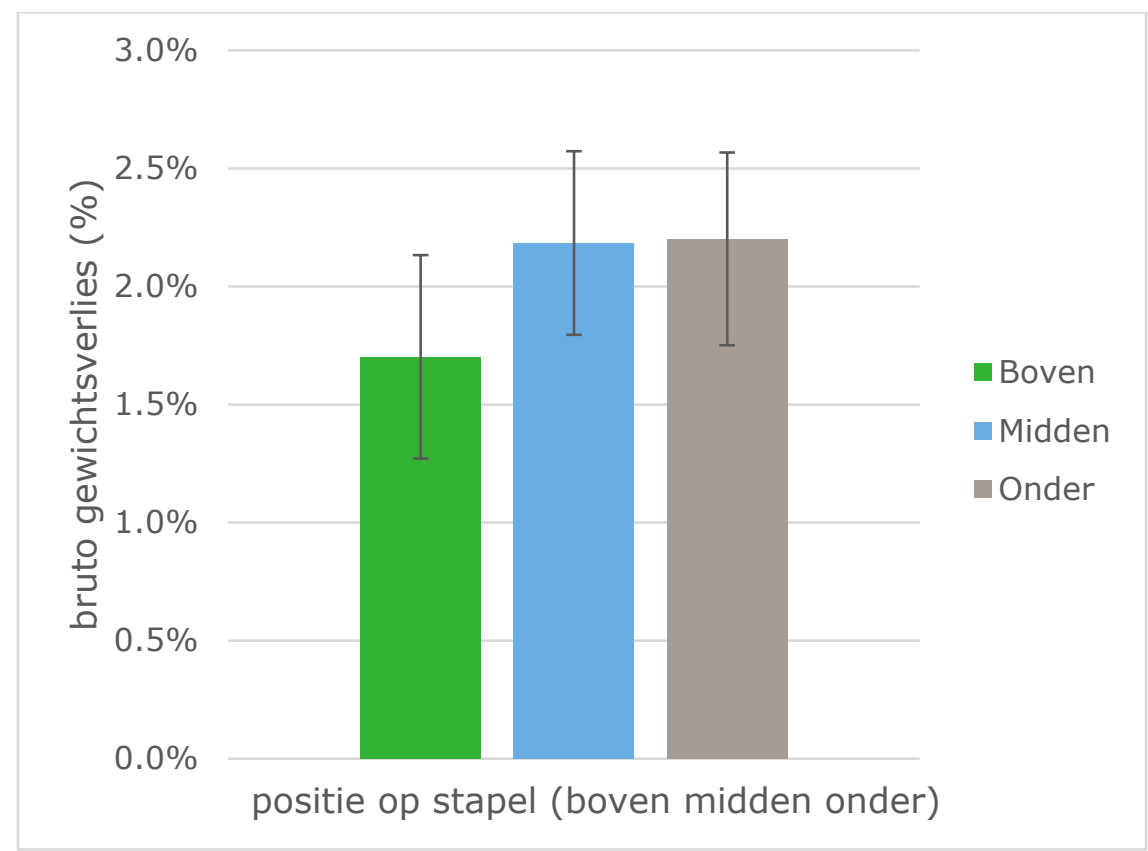

Figuur 9: Invloed van (positie op stapel) op percentage gewichtsverlies. Data zijn gemiddelden \pm standaard deviatie, $n=6$ voor boven en midden, $n=3$ voor onder. 
De combinatie van positie en fusttype geeft een wisselend beeld waarin duidelijk wordt dat de positie bepalender is dan het type fust (Figuur 10).

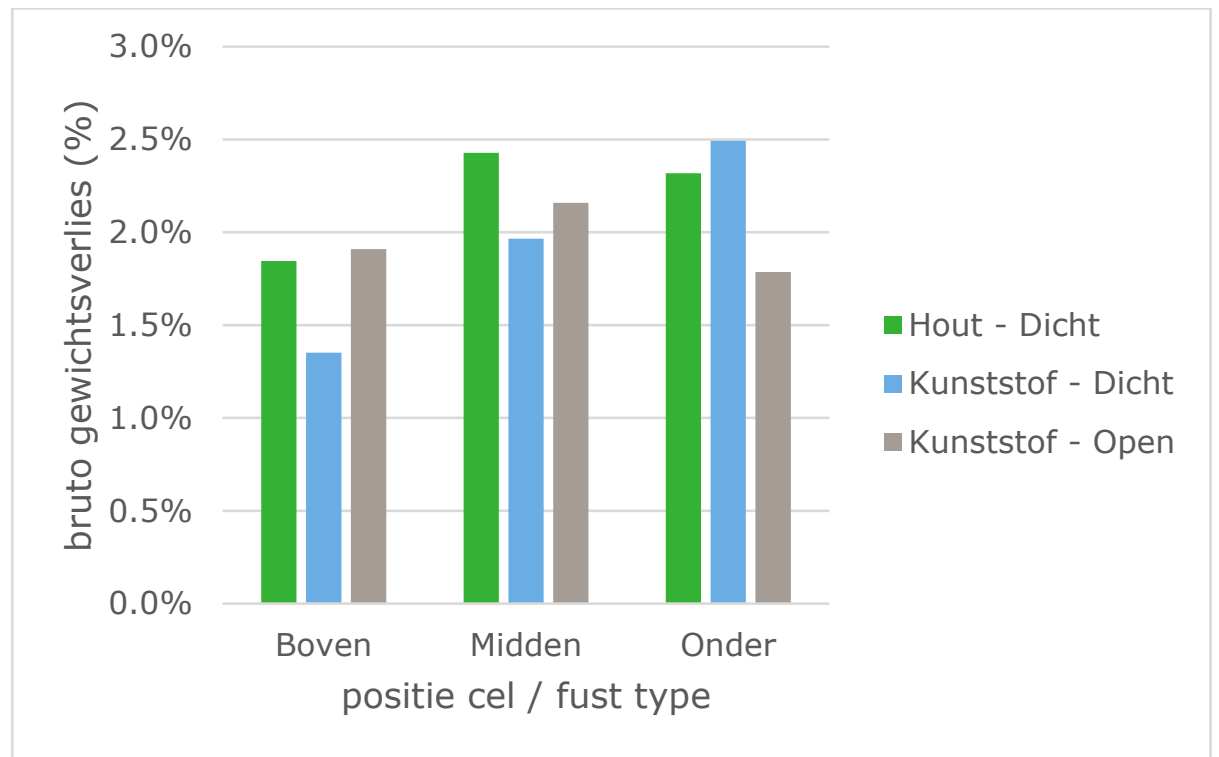

Figuur 10: Invloed van stapelpositie en fusttype op percentage gewichtsverlies. Data zijn gemiddelden $\pm 95 \% \mathrm{CI}, n=3$.

Ook in 2018-2019 werd een gelijk beeld gevonden. Namelijk de grootste verschillen tussen posities en in mindere mate, een niet altijd consistent effect, door fust type. Hout lijkt tot de hoogste gewichtsverliezen te leiden. Dit seizoen 2019-2020 is geen specifiek verschil in schimmelontwikkeling op de peren vastgesteld tussen de verschillende fustsoorten.

\subsubsection{Conclusie}

Op de onderzoeklocatie zijn de verschillen in bruto vochtverliespercentage tussen de verschillende fusttypen over meerdere onderzoekjaren beperkt. Veel belangrijker lijken de posities van de kisten. Kisten boven ( $9^{\mathrm{e}} \mathrm{kist}$ ) op de stapel laten een lager vochtverlies zien dan de kisten midden ( $8^{\mathrm{e}}$ kist op stapel) of kisten onder ( $7^{\mathrm{e}}$ kist op stapel). Kisten boven op de stapel bevinden zich in de koudste positie van de cel. Dit sluit aan bij de bevindingen in de positieproef (Hst 3.4) waarin ook de kisten op de koudste positie minder vochtverlies gaven.

\subsection{Invloed van herkomst}

\subsubsection{Doel}

Impact van herkomst op mate van vochtverlies.

\subsubsection{Inleiding}

In eerdere onderzoekjaren is de invloed van herkomsten bepaald door op twee posities binnen de cel (warm/droger en koud/vochtiger) uiteenlopende herkomsten te plaatsen. Naast de reactie van elk van de herkomsten op het plaatselijke klimaat is ook het effect van herkomst te bepalen. In alle jaren zien we een grotere invloed van de cel positie en een beperkte invloed van de herkomst. Om het model (hoofdstuk 2) te toetsen is ook in seizoen 2019-2020 een reeks herkomsten gemonsterd en beoordeeld op gewichtsverlies op diverse momenten in de bewaring. 


\subsubsection{Materiaal en methode}

\section{Seizoen 2019-2020}

Van 12 herkomsten, met bijzonderheden/variatie in uiterlijke kenmerken passend bij het model (maat/gewicht, mate van bronsheid/gladheid en vorm), zijn op praktijklocaties direct na inslag monsters genomen. Per herkomst werden 4 kratten (EPS midden) verzameld en samengevoegd op een pallet. Een deel van deze kratten werd aangeleverd in Wageningen voor analyse (Hst 2.2); het restant werd opgeslagen in een praktijkcel nabij de deur. De positie van de pallet is getypeerd als warm/droger.

\subsubsection{Resultaten}

De verschillen tussen herkomsten in gemiddeld gewichtsverlies van de kratten met peren na respectievelijk 5 en 29 weken zijn in Figuur 11 weergegeven. De gewichtsverliezen variëren in de eerste 5 weken tussen de 0.8 en $1.2 \%$. De groep herkomsten die in de eerste 5 weken een hoger vochtverlies toont (, , F D , E, L, I, K), geeft ook na 29 weken een relatief hoger vochtverlies in vergelijk met de groep herkomsten met de laagste verliezen in de eerste week. Het verschil in vochtverlies na 29 weken tussen herkomsten blijft kleiner dan een factor 2 .

\section{Vergelijk vochtverlies na 5 en 29 weken}

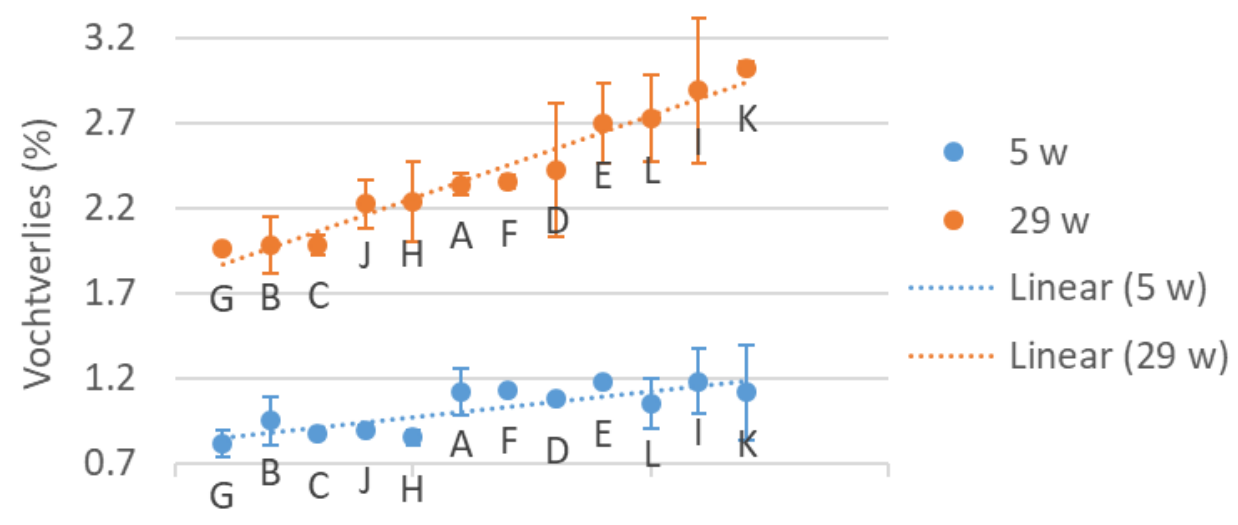

Figuur 11: Netto vochtverlies percentage na 5 en 29 weken bij uiteenlopende herkomsten. Data zijn gemiddelden $\pm 95 \% \mathrm{CI}, \mathrm{n}=2$.

Bij inslag is er door bewaarexpert Frank van de Geijn een inschatting gemaakt van het te verwachten gewichtverlies en slappe nekken ontwikkeling tijdens bewaring op basis van de visuele en bekende eigenschappen (zie Tabel 4 hieronder, overeenkomstig met Tabel 1, Hst 2.2).

Herkomsten A, B, D, G en J werden als goede strakke peren ingeschat, weinig risico. I en $L$ waren moeilijker in te schatten vanwege de gemiddelde uiterlijke kenmerken. En de herkomsten $\mathrm{C}, \mathrm{E}, \mathrm{F}, \mathrm{H}, \mathrm{K}$ werden op het oog als risicopartijen ingeschat.

Tabel 4: Overzicht herkomsten en typering

\begin{tabular}{|c|c|c|c|c|c|c|}
\hline Herkomst & Bodemtype & Grootte & Brons & Vorm & Gevoeligheid vochtverlies (uit ervaring) & Other factors \\
\hline A & - & Erg groot & Laag & Dikke nek & - & Bodemwaterspanning normaal \\
\hline B & - & Erg groot & Laag & Dikke nek & - & Bodemwaterspanning van $-100 \mathrm{kPa}$ \\
\hline $\mathrm{c}$ & Losse grond & Klein & Variabel & Variabel & Bovengemiddeld & Korte bewaring \\
\hline D & Rivierklei / zand mix & Groot & Gemiddeld & Variabel & Laag & - \\
\hline E & Losse grond & Gemiddeld & $\begin{array}{c}\text { Bovengemiddeld } \\
\text { Hoog }\end{array}$ & $\begin{array}{l}\text { Uniform } \\
\text { Variabel }\end{array}$ & Bovengemiddeld & - \\
\hline$\frac{F}{G}$ & Rivierklei & $\frac{\text { Groot }}{\text { Gemiddeld }}$ & \begin{tabular}{|c|} 
Hoog \\
Laag \\
\end{tabular} & $\begin{array}{l}\text { Variabel } \\
\text { Uniform }\end{array}$ & $\frac{\text { Hoog }}{\text { Laag }}$ & - \\
\hline H & Zeeklei & Erg klein & Hoog & Rond, spitse nek & Hoog & - \\
\hline 1 & Zeeklei & Gemiddeld & Gemiddeld & Variabel & Gemiddeld & Wind-damage \\
\hline $\mathrm{J}$ & Rivierklei & Groot & Laag & Uniform & & - \\
\hline $\begin{array}{l}\mathrm{K} \\
\mathrm{L}\end{array}$ & $\begin{array}{l}\text { Rivierklei } \\
\text { Zeeklei }\end{array}$ & $\begin{array}{c}\text { Klein } \\
\text { Gemiddeld }\end{array}$ & $\begin{array}{l}\text { Hoog } \\
\text { Laag }\end{array}$ & $\begin{array}{c}\text { Variabel, spitse nek } \\
\text { Variabel }\end{array}$ & $\begin{array}{l}\text { Bovengemiddeld } \\
\text { Gemiddeld }\end{array}$ & Generally long storage duration \\
\hline
\end{tabular}


Uit de uiteindelijk gemeten gewichtsverliezen en slappe-nekscores (Figuur 12) kunnen we afleiden dat een heel aantal partijen op juiste wijze op het oog in te schatten zijn in de relatieve mate van slappe nek (o.a. A, B, D als strakke peren, K, H, F als slapgevoelig). Toch zijn er ook een aantal partijen waarbij dit afweek van de verwachting. Daarnaast blijkt opnieuw de 1 op 1 relatie tussen vochtverlies en slapgevoeligheid niet dusdanig sterk te zijn dat alleen vochtverlies als leidende factor kan dienen. Herkomsten A en D met weinig slappe nekken hebben procentueel bijna vergelijkbaar vochtverlies als herkomsten $\mathrm{H}$ en $\mathrm{F}$ die een hoge slappe-nekscore hebben.

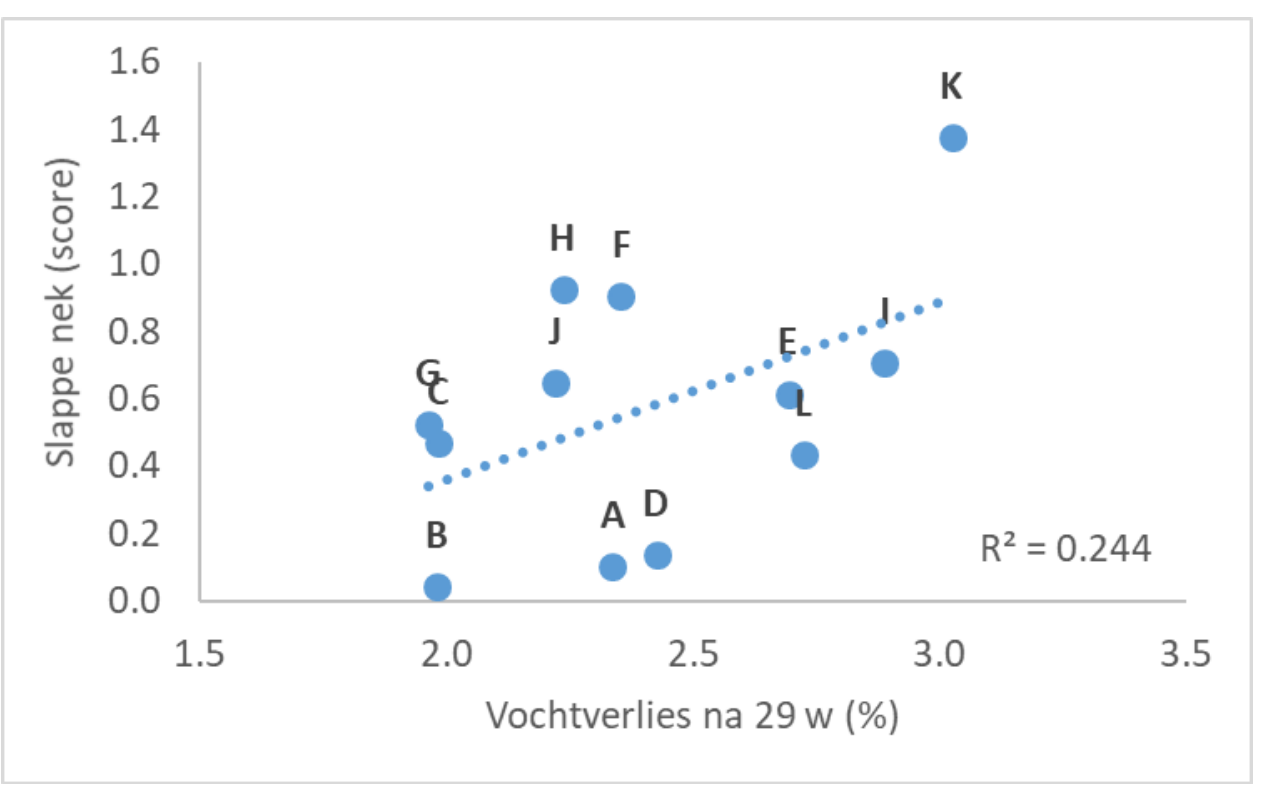

Figuur 12: Gemiddeld netto vochtverlies \% versus gemiddelde slappe-nekscore per herkomst. De trendlijn met $R^{2} 0.244$ betekent een positieve, maar geen sterke correlatie tussen vochtverlies en slappe-nekscore.

\subsubsection{Conclusie}

Bij de selectie van herkomsten bij inslag, op basis van een brede variatie in typische eigenschappen die verband houden met de mate van ontwikkeling van slappe nekken en waarschijnlijk ook met de mate van vochtverlies, blijkt na bewaring ook daadwerkelijk een brede range aan slappe-nekscores en vochtverliezen te zijn gevonden. De gewichtsverliezen na 29 weken bewaring lopen uiteen van 1.9 tot $3.0 \%$. Het inschatten van gevoeligheid voor slappe nekken blijkt in veel gevallen al bij inslag mogelijk. Een verfijning en objectivering van deze methode kan dit nog verbeteren zoals het ontwikkelde model in Hoofdstuk 2.3.2.

\subsection{Vochtverlies en positie in de cel}

\subsubsection{Doel}

Bepalen van vochtverlies verschillen binnen een cel.

\subsubsection{Inleiding}

In het eerste onderzoekjaar bleek dat verschillende herkomsten die geplaatst waren op een typisch warmste (drogere) en koudste (vochtigste) celpositie, een groot verschil in vochtverlies laten zien. Dit was aanleiding om op diverse praktijk locaties van kisten op verschillende cel posities het gewichtsverlies te bepalen. Het doel is te bepalen hoe groot het verschil is en welk deel van de cel de grootste verliezen kent. Het weten van de meest vochtverlies gevoelige positie betekent ook veel voor toekomstige plaatsing van meetapparatuur.

In seizoen 2018-2019 is in diverse cellen een beeld verkregen over de vochtverlies verdeling.

De verschillen in vochtverlies kunnen meer dan een factor 2 zijn tussen positie met minste verlies en 
positie met hoogste verlies. De beste posities (bij 1 bewaarlocatie met meerdere installaties) worden op de bovenste kisten gevonden verder van de verdamper. De positie onder de koeler (vloerniveau) is over het algemeen het slechtste. Op een tweede onderzoeklocatie geven de kistposities dichter bij de verdamper de hoogste verliezen.

In seizoen 2019-2020 is de waarneming herhaald op 2 bewaarlocaties in diverse cellen.

\subsubsection{Materiaal en methode}

\section{Seizoen 2019-2020}

\section{Locatie 1}

Per proefcel, die gevuld is met 1 herkomst, zijn proefkisten (minimaal 11) aangewezen. Weegkisten zijn van 1 herkomst, 1 fusttype en van eenzelfde aanvoermoment. De proefkisten zijn op middelste rij (cel is 5 kisten breed) geplaatst na weging. Plaatsing en codering zijn uitgevoerd volgens onderstaand schema (Figuur 13). Bij uitslag zijn de weegkisten verzameld en op gelijk moment gewogen zodra alle weegkisten beschikbaar waren.

\begin{tabular}{|lllll|}
\hline H & J & I & P \\
& E & F & G \\
A & B & C & D \\
\hline
\end{tabular}

Figuur 13: Zijaanzicht cel met codering van kistposities in de proef. Rechts bevinden zich deur en koeler.

\section{Locatie 2}

Op locatie 2 is in seizoen 2019-2020 bij 2 cellen op 16 unieke verschillende posities gewogen. De plastic kisten met peren zijn bewaard in cel 35 en 62 gedurende respectievelijk 275 en 350 dagen. De posities van de weegkisten zijn volgens een stapelcodering vastgelegd.

\subsubsection{Resultaten}

\section{Locatie 1}

De netto gewichtsverliezen zijn in onderstaand Figuur 14 weergegeven. Hierbij moet opgemerkt worden dat naast een zeer lange bewaring door de fruiteigenaar bewust is aangestuurd op het verhogen van het gewichtsverlies. Dit hoger gewichtsverlies is daadwerkelijk gerealiseerd echter met een zeer grote variatie binnen de cel. 


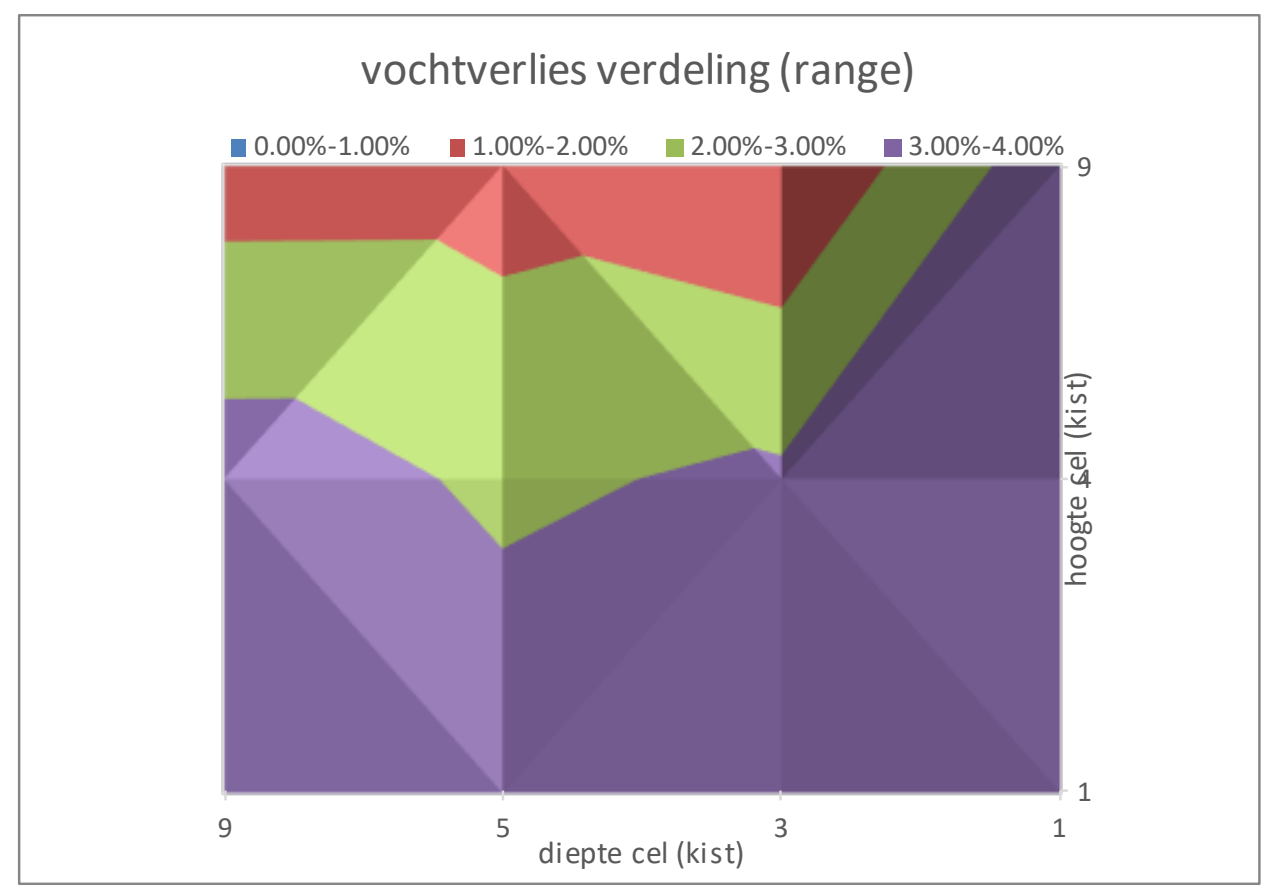

Figuur 14: Zijaanzicht van de cel met rechts de deur en de koeler. Netto gewichtsverliezen (\% ten opzichte van startgewicht peren bij inslag) zijn aangegeven per kistpositie.

De vochtverliezen liggen in dit geval gemiddeld op een hoog niveau (2.9\%) en geven een groot verschil (bijna factor 4) tussen de beste en slechtste positie. Opvallend is dat er geen opmerkingen zijn over het optreden van slappe nekken.

\section{Locatie 2}

De gemiddelde (netto) gewichtsverliezen op locatie 2 zijn berekend als afname van het bruto kistgewicht. $\mathrm{Er}$ is gekozen om niet te corrigeren voor het ledig gewicht van de kisten.

De invloed van de posities (diepte, breedte en hoogte) is geanalyseerd maar doordat per cel verschillende posities zijn gekozen (met tussen de cellen verschillende herkomsten) is een goed vergelijk niet mogelijk.

In Figuur 15 is een overzicht weergegeven van de gemiddelde vochtverliezen op verschillende hoogte voor cel 35. Hiernaast wordt ook het maximale verlies en het minimale verlies op deze kist laag genoemd. Doordat de kisten per laag niet op een gelijke breedte/diepte positie stonden is geen eenduidig vergelijk mogelijk. Wel is duidelijk dat de laagste kistpositie in deze cel de hoogste vochtverliezen geeft. Ook de spreiding tussen kisten op deze laag is relatief groot. De verschillen tussen kist laag 3 en 5 zijn beperkter maar geven wel een trend aan richting een gemiddeld lager verlies naarmate de kist hoger op de stapel staat. De vochtverliezen zijn het meest beperkt op de bovenste kist laag. 


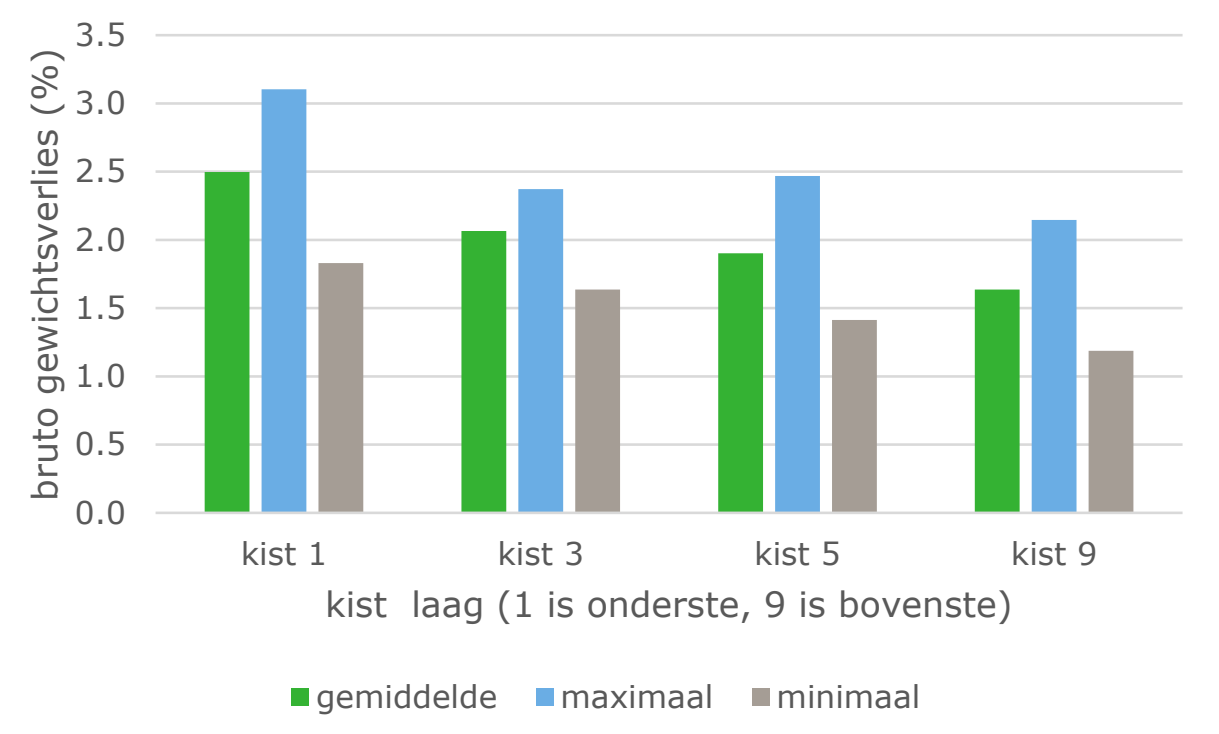

Figuur 15: Gemiddeld gewichtsverlies (en minimaal en maximaal) per kist laag in cel 35.

Een vergelijkbaar beeld is geregistreerd voor cel 62 (Figuur 16). Een dalend verlies bij hoger geplaatste kisten. De uitzonderingen worden hier gevormd door enkele kisten op kist laag 5 en 9 aan de voorzijde van de cel. Dit zijn kistposities nabij de koeler (rij $1 \mathrm{t} / \mathrm{m} \mathrm{3}$ ). Deze kistposities zijn niet geregistreerd in cel 35 .

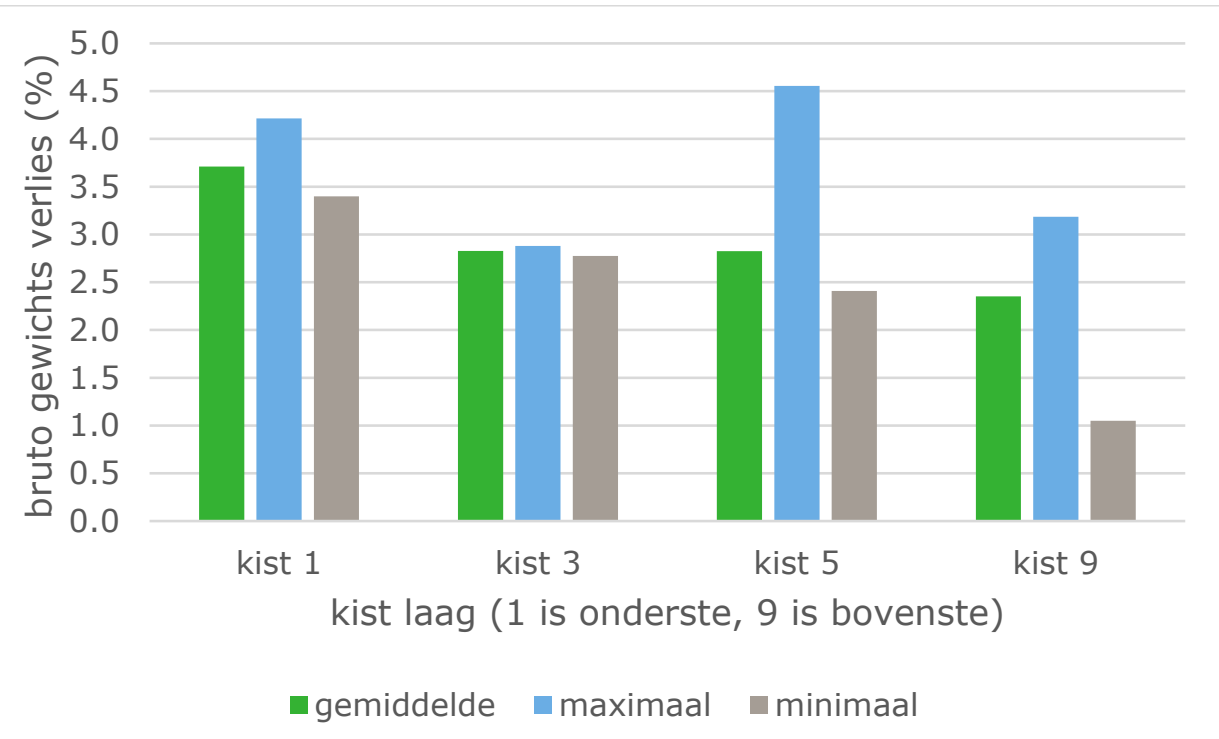

Figuur 16: Gemiddeld gewichtsverlies (en minimaal en maximaal) per kist laag in cel 62.

De bevindingen sluiten aan op de metingen in seizoen 2018-2019.

\subsubsection{Conclusie}

De positie in de cel met het bijbehorende klimaat (temperatuur en vochtigheid) is in hoge mate bepalend voor de mate van vochtverlies. Ondanks een beperkt temperatuur verschil (soms minder dan 0.3 graad) blijkt toch een aanzienlijk verschil in gewichtsverlies te kunnen ontstaan. Als beste posities blijken steeds de kisten op de bovenste laag van de cel, veelal verder van de koeler af. De posities onder de koeler (in directe omgeving van koeler) en op vloerniveau, zijn over het algemeen het slechtste. 


\section{$4 \quad$ Sensoren voor humistatus en klimaat in cel}

\subsection{Introductie}

De mate van vochtverlies tijdens bewaring wordt op dit moment gemeten door het vaststellen van de hoeveelheid condenswater (ontdooiwater van verdamper). Hiermee is per periode (veelal minimaal 1 week) een beeld van het vochtonttrekkingsgedrag van een bewaarcel te krijgen. Het betreft hier een gemiddeld beeld van vochtverlies in een bewaarcel. O.a. in dit Humistatusproject is gevonden dat de verschillen in gewichtsverlies binnen een cel groot kunnen zijn, een factor twee verschil is niet ongewoon maar kan in bepaalde situaties zelfs een factor 4 zijn. Vanwege deze ruimtelijke verschillen is het wenselijk om via eenvoudige en betaalbare sensoren een beeld te krijgen van het lokale vochtverlies. Ook is het voor operators nuttig om dit lokale vochtverlies actueel te kunnen beoordelen, om dit zo mogelijk met andere (koeltechnische) instellingen te kunnen bijsturen.

\subsection{Sensorkandidaten om humistatus te meten}

Een directe meting van de humistatus van een product gedurende bewaring (vochtstatus bij oogst min vochtverlies in bewaring) geeft naar verwachting het meest betrouwbare beeld van de actuele vochtstatus. Aangezien hier nog geen meetmethode voor bestaat, zijn er binnen het project diverse technieken beproefd om in elk geval het lokale vochtverlies in bewaring te kunnen monitoren.

In seizoen 2017-2018 is een opstelling gemaakt met de zogenaamde "YOU-weegunit" (firma Tolsma, Figuur 17). Het is een mogelijke techniek om gedurende het bewaarproces informatie te krijgen over het verloop van het gewichtsverlies in een CA cel. Echter de gebruikte weegtechnologie bleek gedurende het bewaarseizoen niet bijzonder gevoelig en stabiel voor deze toepassing: soms onverklaarbare sprongen in de meetdata -en periodes zonder data- wat betrouwbare dataverzameling en -analyse bemoeilijkte. De beperkte gevoeligheid maakt dat pas na langdurige monitoring iets gezegd kan worden over het verloop van het vochtverlies. De technologie is praktisch lastig opschaalbaar naar een groter aantal posities in de cel omdat dan per kist een sensor gevuld en "ingegraven" moet worden, een bewerkelijke actie in de toch al drukke oogstperiode.

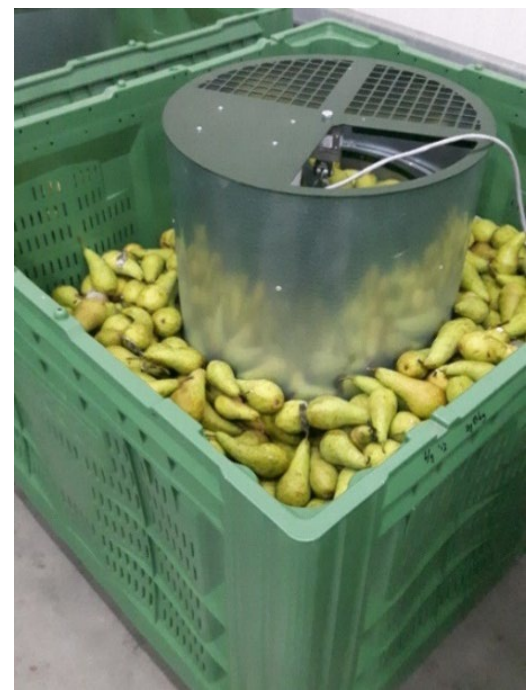

Figuur 17: Impressie van een YOU weegunit gevuld met peren in een kist peren.

Daarnaast zijn er gedurende 3 seizoenen diverse RV- en temperatuurmetingen in de praktijk gedaan om het celklimaat op diverse posities te kunnen monitoren en zo informatie over de mate van vochtverlies te kunnen verkrijgen. De RV-metingen bleken hier onverwachte resultaten te geven ten 
opzichte van het vochtverlies. Een mogelijke reden kan zijn dat het betrouwbaar meten van de RV in praktijk lastiger is dan verwacht. Algemeen aanvaard is dat het vochtverlies mede bepaald wordt door het dampspanningsverschil in het microklimaat rondom het product. Lokale temperatuur, RV en luchtsnelheid zijn dan van belang. Bij deze metingen was de RV tussen de kisten gemeten en niet midden tussen het product. Daarnaast miste de temperatuurmeting op elke positie. Enkel als de RV en temperatuur lokaal en gelijktijdig gemeten worden kan nauwkeurig het lokale dampspanningsdeficit berekend worden om vanuit dit getal het gewichtsverlies te bepalen. Dat was het doel voor metingen bij het derde seizoen, de resultaten worden in Hoofdstuk 4.3 beschreven.

Er is in dat seizoen ook een eerste ervaring opgedaan met de ultrasone afstandmeter van projectpartner Environmental Monitoring Systems (EMS) onder gecontroleerde omstandigheden bij WFBR. Met deze techniek wordt met een ultrasone afstandmeting het "inzakken" van de peren in de kist gemeten. In seizoen 2018-2019 is een eerste ervaring onder praktijkomstandigheden opgedaan, in seizoen 2019-2020 is dit sensorsysteem in een CA-cel beproefd. Bij deze tests is gekeken naar de technische werking en gevoeligheid, praktische toepasbaarheid en er is geprobeerd een relatie te leggen tussen de mate van gewichtsverlies en het sensorsignaal: de inzakking van peren in de kist gedurende het bewaarproces. In Hoofdstuk 4.4 wordt hier verder op in gegaan

\subsection{T en RV metingen}

\subsubsection{Inleiding}

De resultaten van de eerste 2 seizoenen zijn gerapporteerd in het tussenrapport (Brouwer et al., 2019). In dit hoofdstuk wordt verder ingegaan op de metingen van seizoen 2019-2020. Pedak heeft hiervoor zes nieuw ontwikkelde draadloze sensoren ter beschikking gesteld. Deze zijn bij teler Teun Cornelissen in Beers in een perencel geïnstalleerd. Doel van de metingen is tweeledig.

a. Is het mogelijk om met deze draadloze sensoren over een heel bewaarseizoen betrouwbaar en nauwkeurig Ten RV te meten?

b. Is het mogelijk om op basis van deze T en RV metingen het (lokale) gewichtsverlies te voorspellen?

Om deze laatste onderzoeksvraag te kunnen beantwoorden is het kistgewicht bij inslag en uitslag gewogen.

\subsubsection{Materiaal en methode}

Pedak heeft 6 stuks nieuwe realtime T en RV sensoren beschikbaar gesteld. Zie specificaties en foto van de sensoren in Tabel 5 en Figuur 18. Deze draadloze sensoren zijn real time te volgen via een webinterface. Dit is mogelijk door in te loggen op de website www.ovaport.com onder de projectnaam Humistatus (Figuur 19). Vervolgens kun je de actuele waarde of eerder gemeten waardes bekijken en downloaden (Figuur 20). Tevens vind je een overzicht van de alarmmeldingen.

\section{Tabel 5: Specificaties draadloze $T$ en $R V$ sensor}

\begin{tabular}{|l|l|}
\hline & specificatie \\
\hline Merk & Nokeval \\
\hline Type & FT10-RT433-RHT \\
\hline Temperatuur bereik & Pt100 $-30 \ldots+60^{\circ} \mathrm{C}$ \\
\hline Temperatuur nauwkeurigheid & $\pm 0.5^{\circ} \mathrm{C}\left(-30 \ldots+50^{\circ} \mathrm{C}\right)$ \\
\hline Relatieve vochtigheid bereik & $0 \ldots 100 \%$ RH non-condensing \\
\hline Relatieve vochtigheid nauwkeurigheid & $\pm 3 \% \mathrm{RH}$ over $0 . .+50^{\circ} \mathrm{C}$ \\
\hline
\end{tabular}




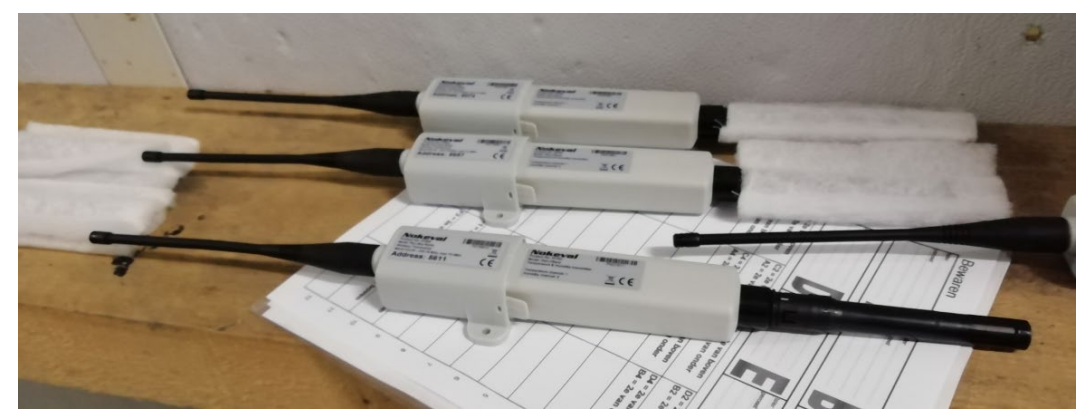

Figuur 18: Foto van draadloze gecombineerde $T$ en $R V$ sensoren.

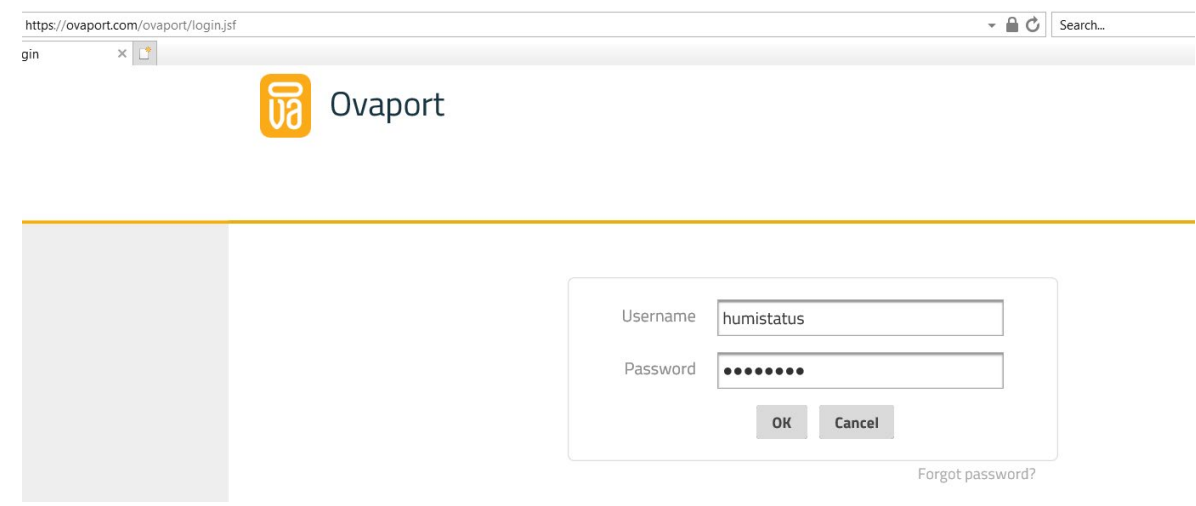

Figuur 19: Inloggen in Ovaport op projectsensoren.

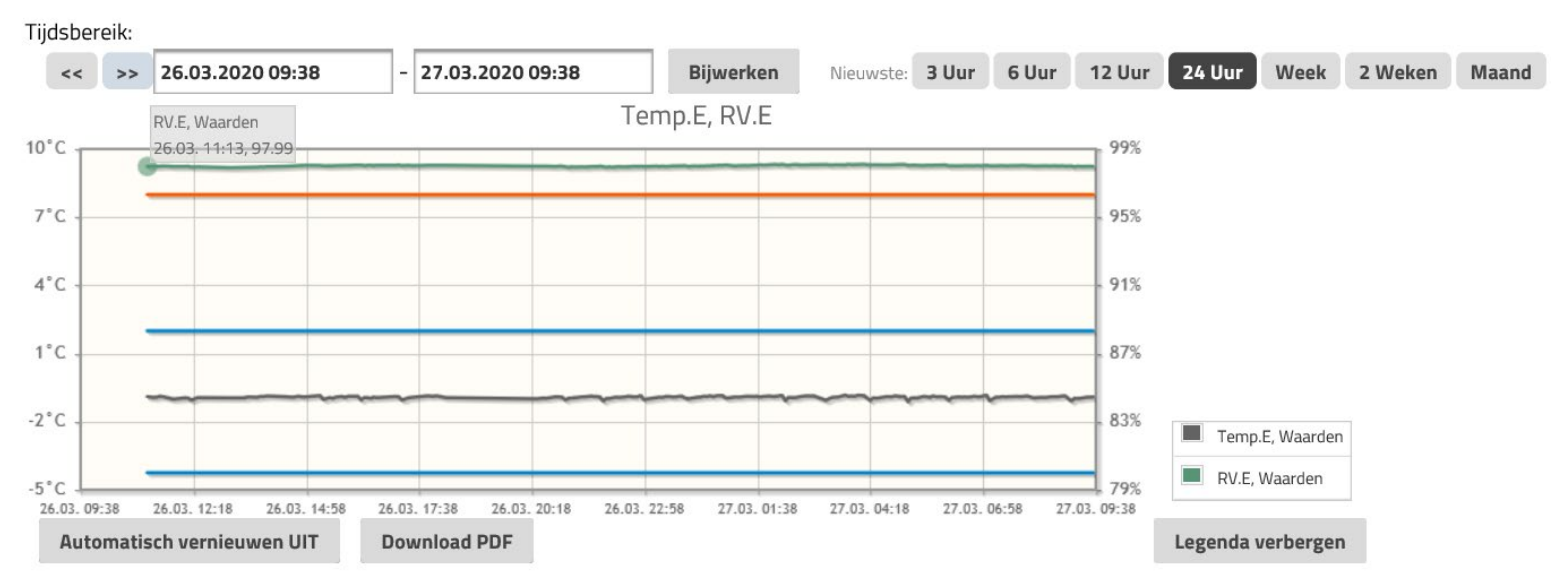

Figuur 20: Screenschot van Ovaport website waar sensor realtime te volgen is.

Op 6 posities in de cel is de T en RV gecombineerd gemeten, zie Tabel 6, en Figuur 21, Figuur 22. De $\mathrm{T}$ en RV wordt in de luchtstoom gemeten in het kruis van 4 kisten, op halve kist hoogte (Figuur 23). Er worden $6 \times 4=24$ kisten gewogen. Er is gewerkt met droog plastic fust en allemaal dezelfde herkomst peren. 
Tabel 6: Omschrijving sensorposities

\begin{tabular}{|l|l|}
\hline Aanduiding positie & Omschrijving positie \\
\hline A & $\begin{array}{l}\text { Verdamperzijde links onder } \\
\left(2^{\mathrm{e}} \text { kist van onder, } 1^{\mathrm{e}} \text { en } 2^{\mathrm{e}} \text { slag }\right)\end{array}$ \\
\hline B & Verdamperzijde rechts onder \\
\hline C & $\begin{array}{l}\text { Verdamperzijde links boven } \\
\left(9^{\mathrm{e}} \text { kist van onder } 1^{\mathrm{e}} \text { en } 2^{\mathrm{e}} \text { slag) }\right.\end{array}$ \\
\hline D & verdamperzijde rechts boven \\
\hline E & $\begin{array}{l}\text { Deurzijde links boven } \\
\text { (9e kist van onder, slag } 10 \text { en } 11)\end{array}$ \\
\hline F & Deurzijde rechts boven \\
\hline
\end{tabular}

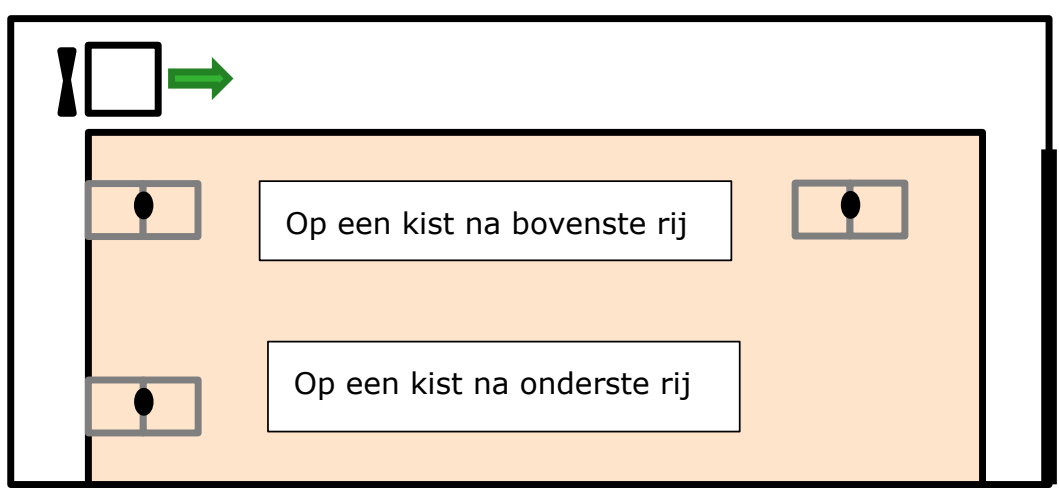

Figuur 21: Zijaanzicht perencel

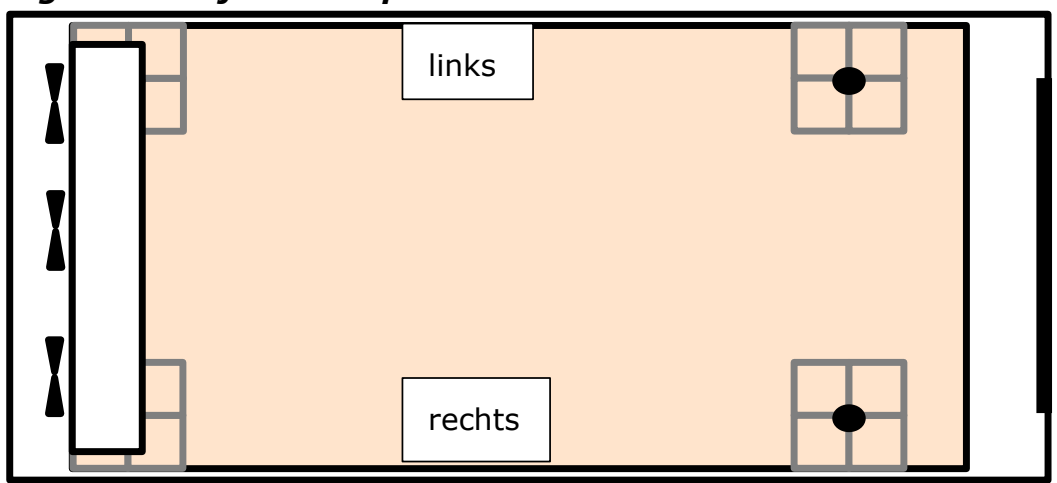

Figuur 22: Bovenaanzicht perencel.

Onderlinge nummering van groepje van 4 kisten

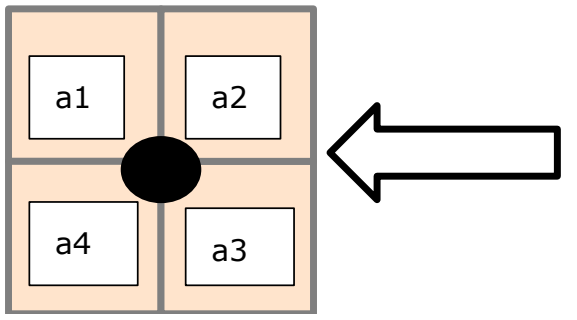

Met de klok mee genummerd gezien vanuit rijrichting met plaatsen heftruck

Figuur 23 Bovenaanzicht nummering kisten.

\subsubsection{Resultaten}

De T en RV metingen zijn 2 september 2019 ingezet. De grafieken van de verschillende meetposities, gebaseerd op een download van 26 maart zijn weergegeven in Bijlage 1. Wat opvalt is dat er soms stukken data missen, maar dat de loggers niet gestopt zijn met meten. Ook lijkt er soms sprake te zijn van ruis, maar bij verder inzoomen op de tijdschaal blijkt dat dit veroorzaakt wordt door de individuele koelacties welke heel mooi zichtbaar geregistreerd worden!

De gemiddelde gemeten waardes over de periode 27 augustus 2019 tot 24 juni 2020 zijn in Tabel 7, in Figuur 24 en Figuur 25 weergegeven. 
Tabel 7: Bruto gewichtsverlies in de periode 27 augustus 2019 - 24 juni 2020

\begin{tabular}{llclc} 
Positie & $\begin{array}{l}\text { Bruto gewichtverlies } \\
(\%)\end{array}$ & Gemiddelde T $\left({ }^{\circ} \mathbf{C}\right)$ & Gemiddelde RV $(\%)$ & $\begin{array}{l}\text { Gemiddelde } \\
\text { dampspannings } \\
\text { deficiet [kPa] }\end{array}$ \\
\hline A & 2.5 & -0.87 & 97.5 & 0.01 \\
\hline B & 1.6 & -0.77 & 97.5 & 0.02 \\
\hline D & 1.8 & -0.88 & 97.7 & 0.01 \\
\hline E & 1.0 & -0.76 & 97.7 & 0.02 \\
\hline F & 1.7 & -0.69 & 97.4 & 0.01 \\
\hline gemiddeld & 3.9 & -1.14 & 98.8 & 0.004 \\
\hline
\end{tabular}

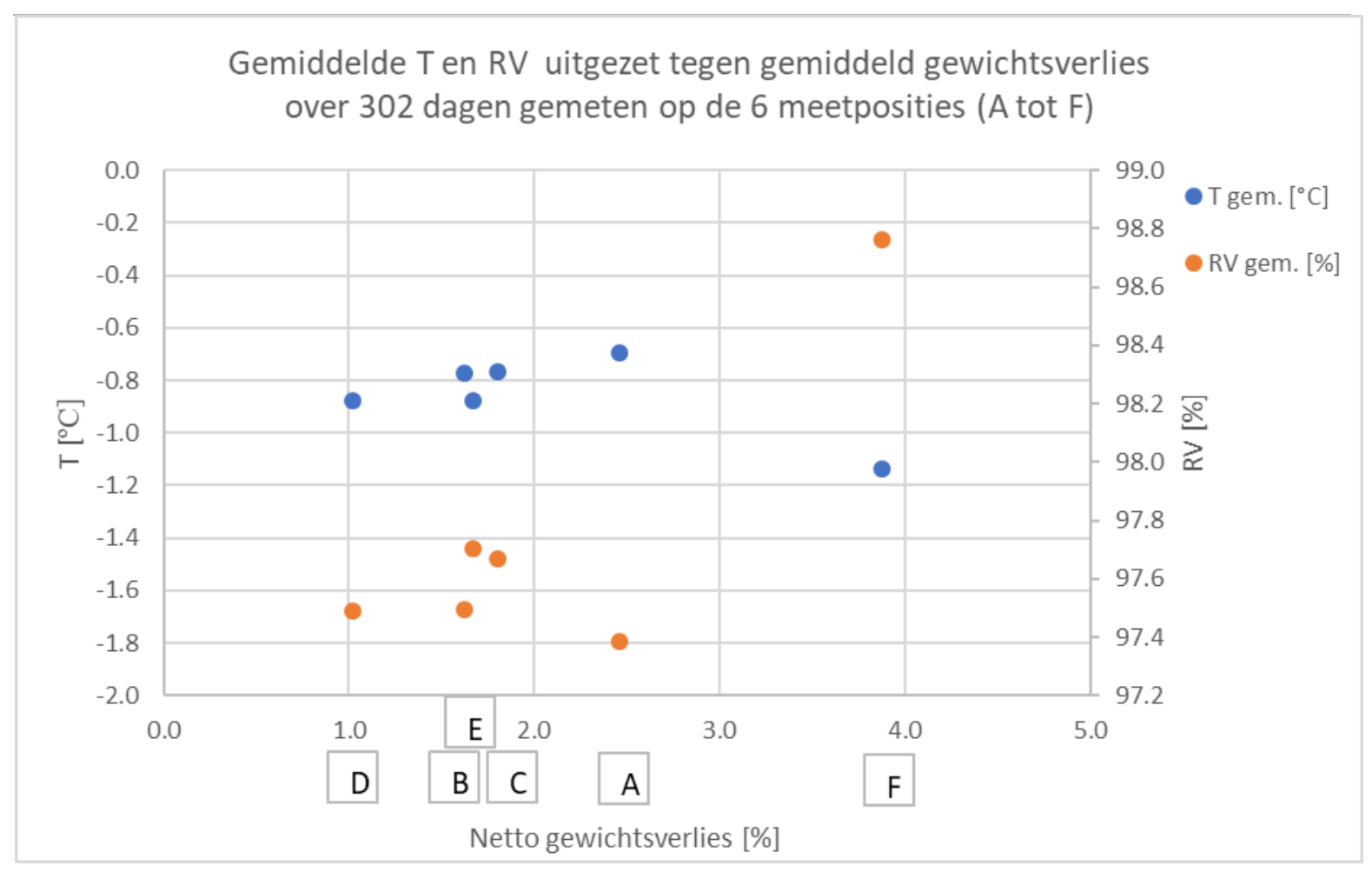

Figuur 24: Gemiddelde T en RV op de verschillende posities grafisch weergegeven.

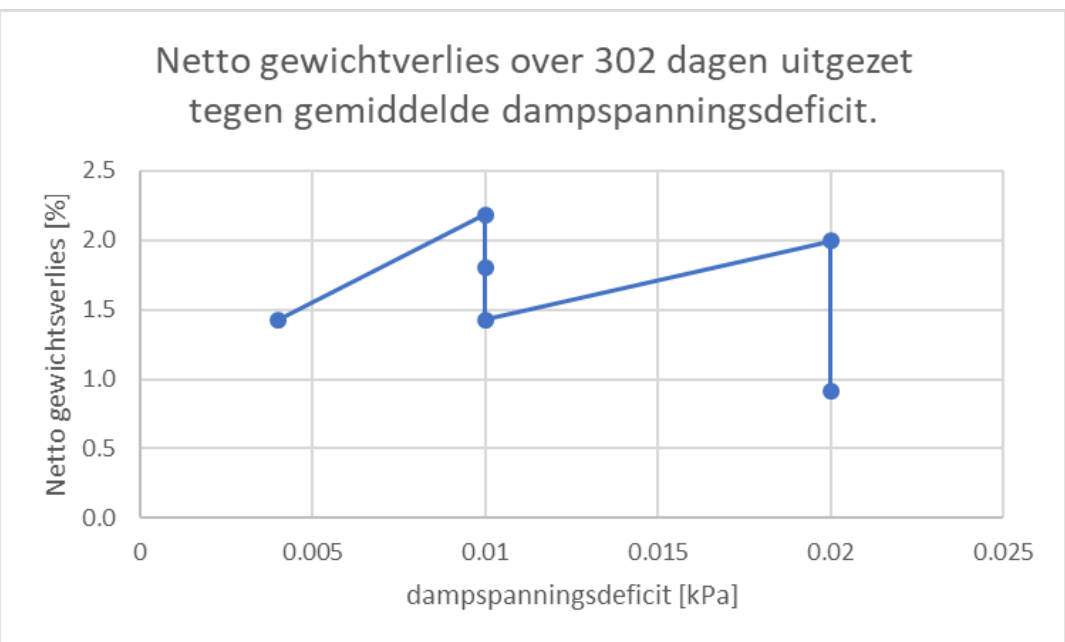

Figuur 25: Gewichtsverlies uitgezet tegen dampspanningsdeficit. 


\subsubsection{Conclusie}

- De temperatuur en RV kunnen draadloos goed en nauwkeurig gemeten worden en is praktisch eenvoudig uitvoerbaar. Positionering van ontvangststation verdient aandacht.

- Normaal gesproken is de verwachting dat bij het toenemen van het dampspanningsdeficit het gewichtsverlies hoger zal zijn. Uit controle van de gemeten waarden komt dit verband niet naar voren. Ook niet als positie $F$, dat een opvallende uitschieter is, niet beschouwd wordt. Het is dus niet vanzelfsprekend dat met T en RV metingen, waarmee het dampspanningsdeficit berekend kan worden, een voorspelling gemaakt kan worden van het gewichtsverlies.

- Met betrekking tot kwaliteit was er sprake van serieus weinig rot en score op slappe nek was redelijk.

\subsection{Ultrasone afstandmeter}

\subsubsection{Inleiding}

Om het vochtverlies van peren in praktijkbewaring te kunnen monitoren wordt in de praktijk vaak het condenswater van de verdamper gemeten. Dit geeft een globale schatting van vochtverlies op celniveau, die weliswaar gerelateerd is met het werkelijke vochtverlies, maar ook door andere factoren beïnvloed kan worden, bv. vochtinbreng door de scrubber. Weging van kisten voor en na de bewaring geeft een veel nauwkeuriger beeld, waarbij ook de spreiding in vochtverlies binnen de bewaarcel helder kan worden. Dit is echter informatie achteraf, dus zonder mogelijkheden tot tijdig ingrijpen/bijsturen. Een directe monitoring zoals weging met een weegunit in de bewaarcel kent de nodige beperkingen zoals daar beschreven.

In dit project is het idee ontstaan om de vulhoogte van de bewaarkisten te monitoren middels een ultrasoon-sensor. Dit meetprincipe wordt bijvoorbeeld gebruikt bij de parkeerhulp in auto's. Naarmate de peren meer vocht verliezen, krimpen ze en daalt de vulhoogte in de kist. Hiervoor is met een door partner EMS (voor een ander doel) ontwikkelde nauwkeurige ultrasoon sensor in een labomgeving getest of de nauwkeurigheden goed genoeg waren voor een kansrijke praktijktoepassing (Figuur 26).

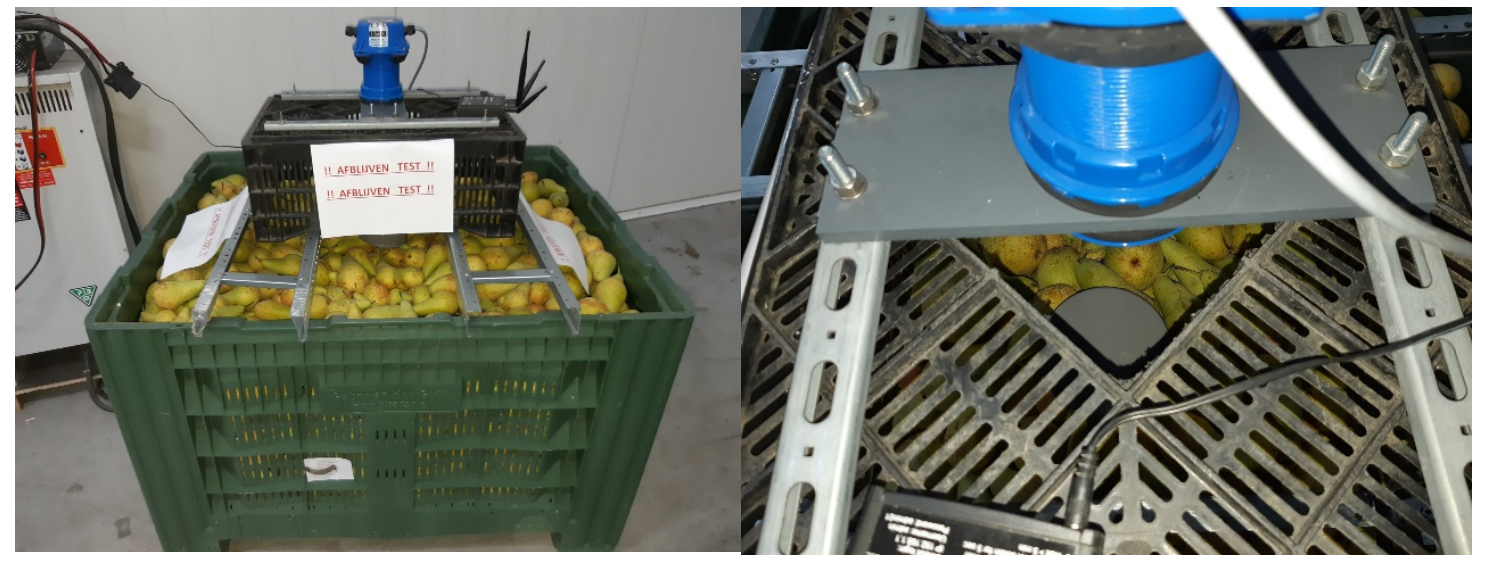

Figuur 26: Opstelling meting met EMS-afstandsmeter.

\subsubsection{Eerdere onderzoekservaringen}

In seizoen 2017-2018 werd voor het eerst in een praktische omgeving gemeten met deze EMSafstandmeter. In seizoen 2018-2019 werd de opstelling in een bewaarcel geplaatst. Helaas bleek de datacommunicatie van de afstandmeting onvoldoende om goed te kunnen beoordelen of de sensor in potentie bruikbaar was. De sensor is in de tweede helft van seizoen 2018-2019 in een mechanische koelcel geplaatst. Naast deze registratie is de kist op een aantal momenten gewogen, zie Figuur 27 voor deze ruwe data. De data is vervolgens gecorrigeerd voor de schokken in de data veroorzaakt 
door de weegmomenten (Figuur 28). Na correctie is er een goede relatie $\left(R^{2}=0.95\right)$, te zien tussen de afstandsmeting (mate van inzakking peren) en het gewichtsverlies (Figuur 29). Dit biedt perspectief voor het gebruik van een afstandsmeting als maat voor gewichtsverlies tijdens de bewaring.

De gemeten toename in afstand tussen de bovenkant van de bewaarkist en de peren ligt in dezelfde grootte-orde als met de op basis van de werkelijke gewichtsverliezen berekende krimp (gemeten gewichtsverlies $0.28 \mathrm{~kg} / \mathrm{dag}$, berekend gewichtsverlies is $0.31 \mathrm{~kg} / \mathrm{dag}$ (uitgaande van $0.726 \mathrm{~kg}$ peren/mm in een kuubskist* en $0.431 \mathrm{~mm}$ daling/dag).

* Schatting kist intern volume $=1.1 * 1.1 * 0.6=0.73 \mathrm{~m}^{3}$, bij stortingsdichtheid $600 \mathrm{~kg} / \mathrm{m}^{3}$ geeft dat $436 \mathrm{~kg}$, bij vulhoogte $60 \mathrm{~cm}$ is dat $0.726 \mathrm{~kg} / \mathrm{mm}$

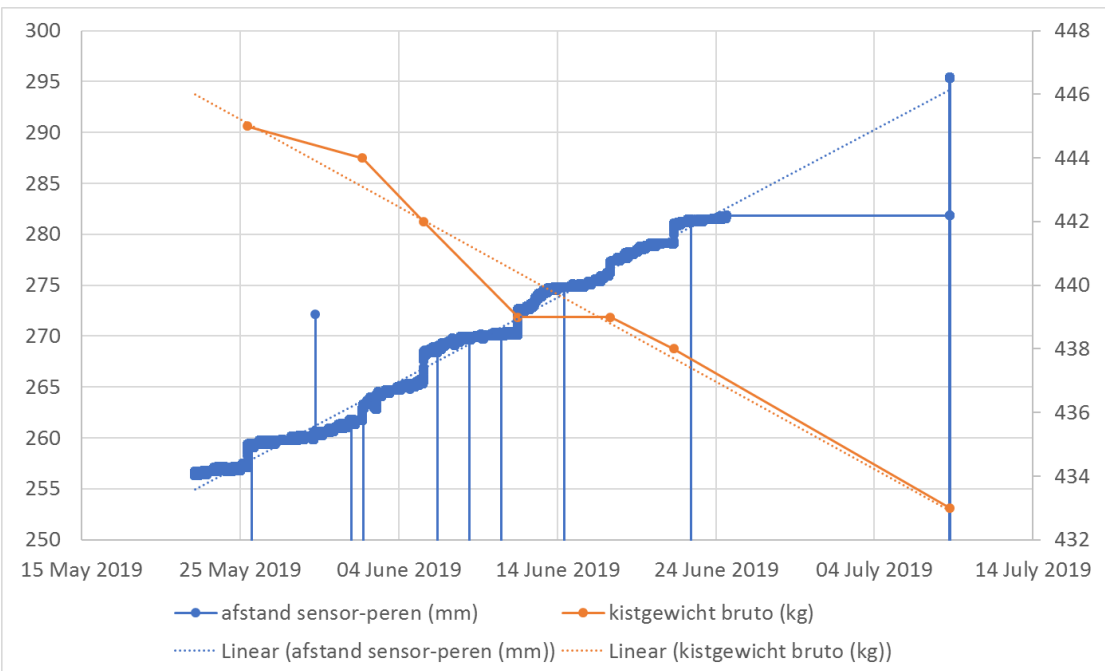

Figuur 27: Meetresultaten met afstandsmeter en kistwegingen (ongecorrigeerd).

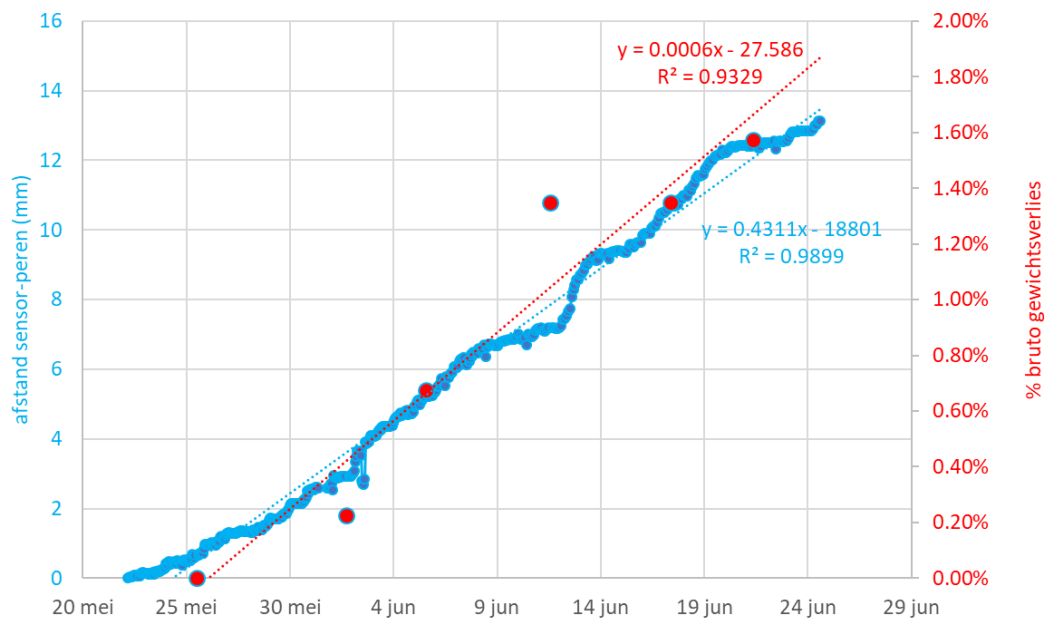

Figuur 28: Gecorrigeerde data bruto gewichtsverlies en gemeten afstand sensor tot peren gedurende bewaring. 


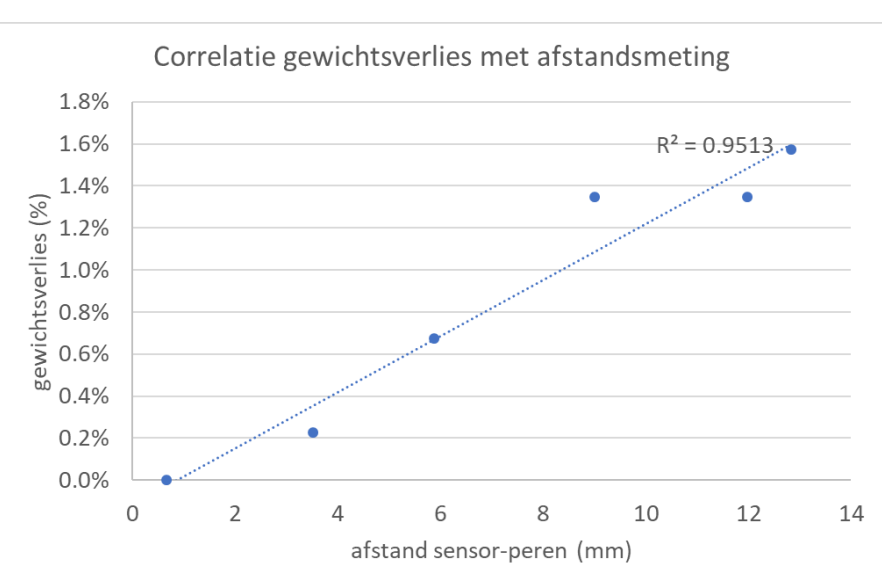

Figuur 29: Relatie tussen bruto gewichtsverlies en gemeten afstand sensor tot peren gedurende bewaring.

\subsubsection{Resultaten}

In seizoen 2019-2020 werd de Ultrasoon-sensor voorzien van verbeterde datalogging en communicatie, en in de wachtperiode na inslag (voorafgaand aan CA-bewaring) geïnstalleerd in een CA-bewaarcel met Conference peren. Helaas bleek dat door miscommunicatie verzuimd was om naast de installatie van de sensor ook vulhoogte en bruto/netto gewicht van de te monitoren kist te bepalen. Doordat de CA cel inmiddels afgevuld was toen dit duidelijk werd, was het niet mogelijk dit alsnog te doen. Daardoor was het niet mogelijk de relatie tussen vochtverlies en de gemeten sensordata hard te correleren. Rest slechts het ervaring opdoen met metingen onder condities met zeer laag vochtverlies. De gebruikte perencel bevindt zich namelijk in een koelcomplex met zeer goede isolatie en met een van de beste (minst vochtonttrekkende) koelinstallaties van Nederland. Eerdere ervaringen in dit complex zijn dat een vochtverlies van ongeveer $1.5 \%$ over 8 maanden gemiddeld is.

Gedurende de ruim 6.5 maanden die de ultrasoon-sensor actief is geweest (19 september 2019 10 april 2020) vielen enkele bijzonderheden op, zie Figuur 30.

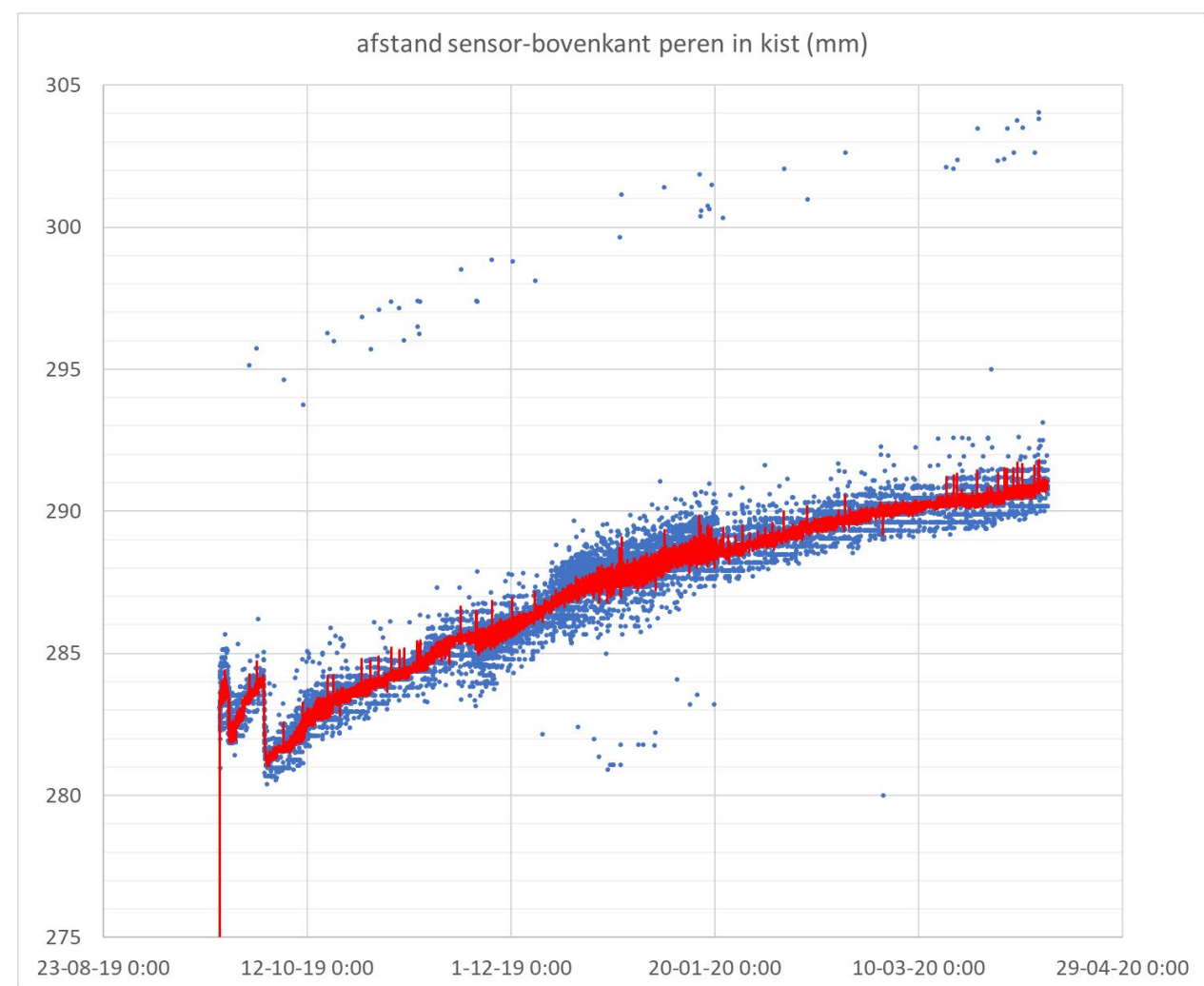

Figuur 30: Ruwe data gemeten afstand sensor tot peren gedurende bewaring. De blauwe punten zijn meetwaarden, de rode lijn een lopend gemiddelde. 
- In de periode 1 oktober 2019 - 10 april 2020 (192 dagen) lijkt de sensor continu goed te functioneren. In deze periode is de vulhoogte van de kist met $10 \mathrm{~mm}$ gedaald, wat overeenkomt met een geschat vochtverlies van $1.3 \%$. Dit lijkt goed in lijn met de praktijkervaringen.

- Over deze periode is de gemiddelde inzakking van de peren $0.058 \mathrm{~mm}$ per dag. Ondanks de spreiding van 3-4 mm tussen individuele meetwaarden (en ca. $1 \mathrm{~mm}$ spreiding in het lopende gemiddelde per kwartier) lijkt de gevoeligheid groot genoeg om het proces van inzakking/uitdroging voldoende nauwkeurig te kunnen monitoren.

- $\quad$ Regelmatig incidentele meetwaarden die duidelijk afwijkend zijn en buiten de gebruikelijke spreiding vallen. Ook hiervan is de oorzaak niet helder, maar deze metingen zijn met datafiltering te verwijderen en belemmeren het functioneren van de sensor verder niet.

- $\quad$ Een grote sprong (daling) op 1 oktober 2019 bleek niet te verklaren door vochtverlies gerelateerde activiteiten in de cel, omdat het om niet abrupte maar geleidelijke veranderingen over een periode van vele uren gaat. Dit bleek samen te vallen met de start van het CA regime, op dat moment bleek de pull down van de cel geweest te zijn: Door injectie van stikstof is het zuurstofgehalte verlaagd van 21 naar ca. 5\%, zie Figuur 31 . Bij doorontwikkeling van deze sensor zal dan ook rekening gehouden moeten worden met eventuele correctie voor het zuurstof (en mogelijk ook het $\mathrm{CO}_{2}$ ) gehalte. 


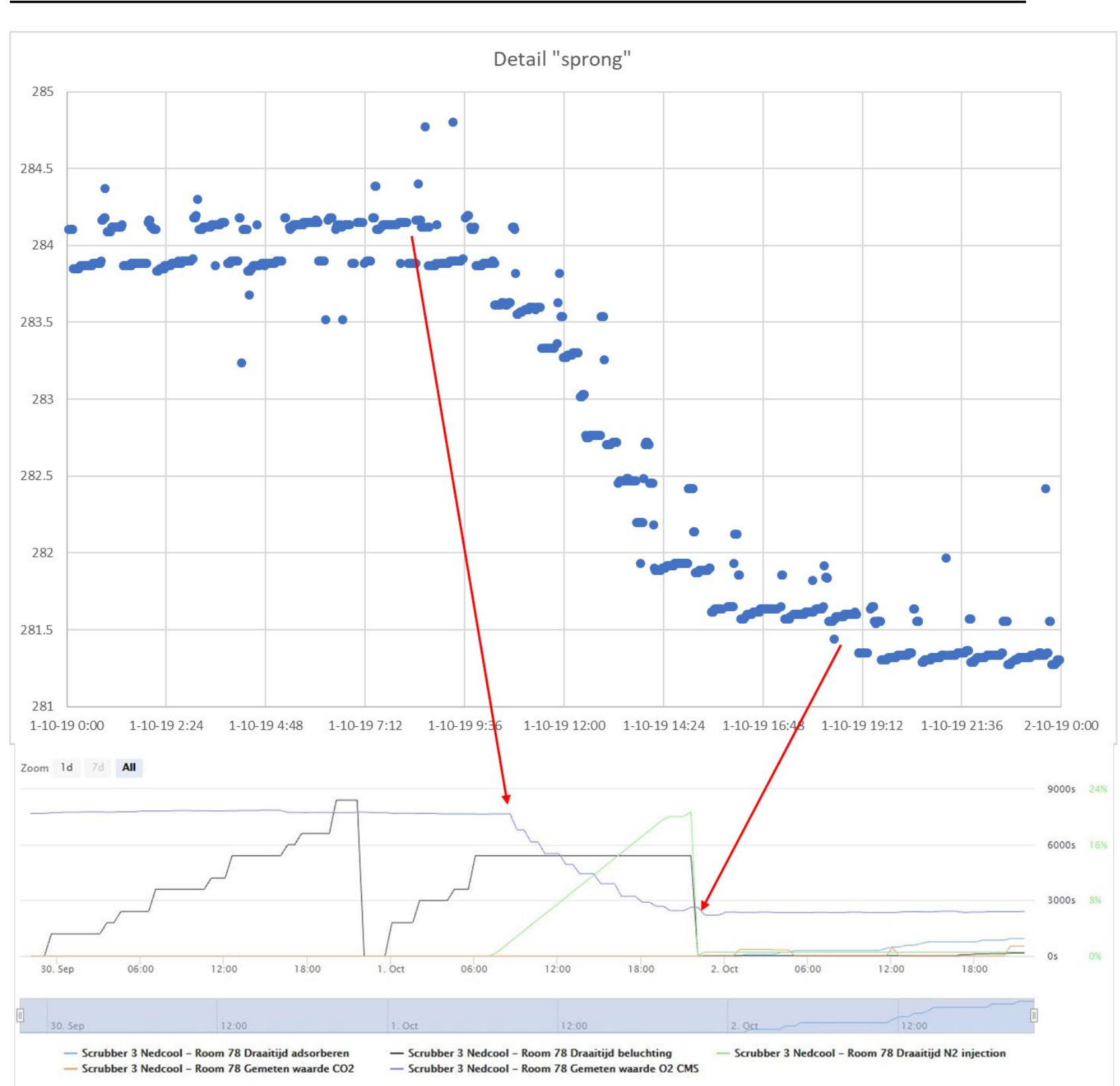

Figuur 31: De pulldown zichtbaar in het signaal van de ultrasoonsensor. Met deze gevoeligheid van ultrasoonsensoren dient rekening gehouden te worden bij doorontwikkeling.

\subsection{Conclusie en aanbevelingen vervolg}

\section{Gewichtsverliesmonitoring met YOU weegunit}

De metingen van de weegunits (YOU's) correleren met daadwerkelijke gewichtsverliesmetingen bij uitslag, maar deze methode kent ook de nodige beperkingen. Zo is de meting niet stabiel in de tijd en kan alleen over een langere meetperiode een verlies bepaald worden.

\section{RV en temperatuur monitoring}

De wens is om lopende het bewaarseizoen een beeld te krijgen van het gewichtsverlies en daarmee uitdroging en om daarmee (eventueel gekoppeld aan de vastgestelde humistatus bij inslag) het risico op slappe nek (en/of rot) in te kunnen schatten en zo mogelijk bij te kunnen sturen door gewijzigde instellingen. Een bruikbaar signaal voor een verandering per week is wenselijk.

De temperatuur en RV kunnen draadloos goed en nauwkeurig gemeten worden en dit blijkt ook praktisch eenvoudig uitvoerbaar. Positionering van ontvangststation verdient wel aandacht. 
Echter het meten van T en RV om deze te vertalen naar een actuele humistatus of een gewichtsverlies lijkt op dit moment niet mogelijk. De resultaten tonen geen verbanden. De verwachting was dat bij het toenemen van het dampspanningsdeficit het gewichtsverlies hoger zou zijn. Uit controle van de gemeten waarden komt dit verband niet naar voren. Het is dus niet vanzelfsprekend dat met T en RV metingen, waarmee het dampspanningsdeficit berekend kan worden, een voorspelling gemaakt kan worden van het gewichtsverlies. Mogelijk mist hier de factor luchtsnelheid.

\section{Gewichtsverliesmonitoring met ultrasoon sensor}

De ultrasone afstandmeter van EMS lijkt gezien de resultaten een potentiële sensor voor het rechtstreeks meten van gewichtsverlies. De techniek leent zich voor doorontwikkeling naar een sensorsysteem op kistniveau (verkleining, IoT datamanagement) om zo op verschillende posities in de bewaarcel gewichtsverlies te kunnen monitoren. Hierbij dient wel rekening gehouden te worden met de in dit project gevonden gevoeligheid voor gewijzigde gassamenstelling in CA cellen, met name qua zuurstofgehalte. 


\section{Invloed van koelsysteem op de intensiteit en stabiliteit van de koelactie tijdens bewaring}

\section{$5.1 \quad$ Inleiding}

EU-regelgeving rondom koudemiddelenregulering dwingt af dat steeds meer applicaties, dus ook fruitbewaring, moeten overstappen naar koelsystemen met natuurlijke koudemiddelen. Voor grote koelsystemen in de fruitbewaring, die gebruik maken van ammoniak als koudemiddel, is deze ontwikkeling niet relevant. Het zijn juist de kleinere koelinstallaties, gebruik makend van synthetische koudemiddelen, die de overstap moeten maken naar laag GWP (Global Warming Potential) koudemiddelen. Meest logische stap voor deze kleine en middelgrote systemen is om dit te realiseren met de overstap naar natuurlijke koudemiddelen, zoals $\mathrm{CO}_{2}$ en propaan.

Uitdaging is om een veilig, betaalbaar en technisch goed functionerend koelsysteem te ontwikkelen. Relevant binnen dit project is de aanvullende uitdaging bij bewaring van versproducten om het vochtverlies te sturen (veelal zo laag mogelijk) en de temperatuurverdeling zo gelijkmatig mogelijk te houden.

\subsection{Opzet/aanpak}

De metingen zijn gericht op het in kaart brengen van de mogelijke invloed van het type koelsysteem en het koudemiddel op de korte krachtige koelactie. Het onderzoek wordt uitgevoerd voor verschillende systemen in de praktijk met behulp van een infrarood-warmtebeeldcamera en temperatuurvoelers. In het bewaar seizoen 2019/2020 zijn aanvullend de laatste twee ontbrekende type koelsystemen gemeten: R404a DX en CO2 DX. Er is voor een CO2 DX systeem gekozen, omdat er geen fruit bewaar locatie beschikbaar is om metingen op een $\mathrm{CO} 2$ pompsysteem uit te voeren.

\subsubsection{Achtergrond}

Bij het onderzoeken van de korte krachtige koelactie van een koelerblok van fruitbewaring, zie Figuur 32 , is het van belang om de volgende zaken vast te stellen:

1. hoe snel het blok afkoelt na start koelactie

2. temperatuurniveau en -verdeling in lengte, hoogte en diepte van het blok tijdens de koelactie

3. duur van nakoeleffect na beëindiging van koelactie.
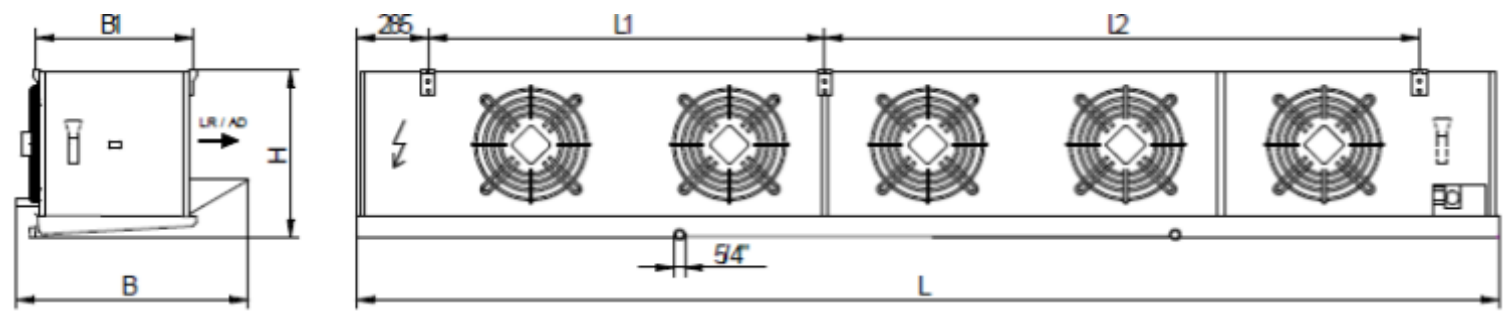

Figuur 32: Typische lange uitvoering van een fruitkoeler met 5 of 6 ventilatoren.

Om dit te kwantificeren zou het wenselijk zijn direct koudemiddelzijdig het koelvermogen te meten. Echter het meten van het massadebiet van het koudemiddel dat verdampt is niet eenvoudig in een bestaande verdamper, zeker niet in geval van een pompsysteem. Alternatief is om luchtzijdig het koelvermogen te meten via luchtdebiet en (gemiddelde) temperatuur en RV-condities van de in- en uittredende lucht. Ervaring leert dat de nauwkeurigheid beperkt is, omdat er ook condensatie van 
waterdamp optreedt. Daarnaast zijn we vanuit vochtonttrekking aan het product juist geïnteresseerd in de temperatuurverschillen die optreden in het koelerblok. Er is daarom gekozen om de prestaties van de verschillende type koelsysteem en koudemiddelen te vergelijken op basis van de (verdeling) van de bloktemperatuur tijdens korte krachtige koelacties.

Om het totale temperatuurprofiel van het koelerblok te meten, moeten zowel de fin- als circuittemperaturen in de lengte $(L)$, hoogte $(H)$ en diepte $(B)$ gemeten worden. In de praktijk zijn er twee uitvoeringen wat betreft de circuitconfiguratie: horizontaal en verticaal (Figuur 33).

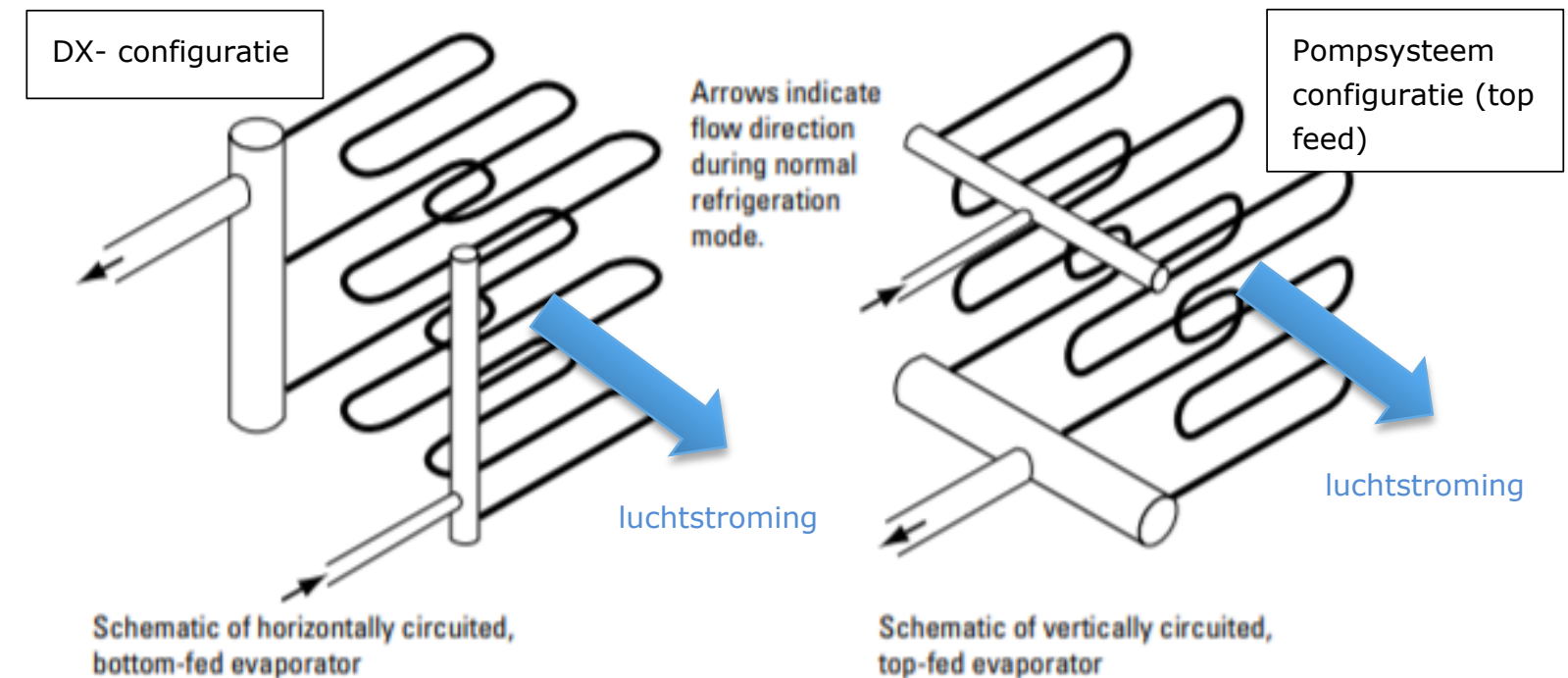

Figuur 33: Overzicht circuitconfiguraties met links de DX-configuratie (bottom feed) en
rechts de pompsysteemconfiguratie (fan top feed).

Horizontale circuits worden toegepast bij DX- en indirecte systemen, waarbij er deels gebruik gemaakt wordt van tegenstroom principe. De intrede van het koelmedium (laagste temperatuur) zit aan de uitblaaszijde van de luchtkanalen. Verticale circuits worden toegepast bij pompsystemen. Waarbij er sprake kan zijn 'top feed' (koudemiddel intrede aan bovenzijde) of 'bottom feed' (koudemiddel intrede aan onderzijde). Deze laatste is de meest voorkomende, omdat deze in alle deellastsituaties het optimale koelvermogen levert.

Omdat circuits meerdere keren op en neer gaan, kan door het meten van de temperatuur bij in- en uittrede en die van de bochten, een goed beeld gekregen worden van de prestaties van een circuit over de hele lengte.

Het te verwachten temperatuurverschil over de lengte van het circuit heeft een aantal mogelijke oorzaken:

- Koudemiddelzijdige drukval in het circuit (afname van temperatuur richting uittrede).

- $\quad$ Slechte of geen benatting inwendige buis in circuit door de koudemiddel vloeistof (vroegtijdig ontstaan van oververhitting door te geringe hoeveelheid vloeistof aan het einde van het circuit). Er wordt te weinig koudemiddel ingespoten in het circuit.

- Indien koudemiddel een 'glide' heeft (toename van temperatuur richting uittrede).

Dit is in praktijk vast te stellen met behulp van een IR-warmtebeeldcamera en logsysteem met temperatuurvoelers.

Met de warmtebeeldcamera kan een algemeen temperatuurbeeld worden verkregen. Omdat de meting afhankelijk is van de stralingseigenschappen van het oppervlak en daarbij de hoeveelheid afstraling van koude oppervlaktes beperkt is, is de nauwkeurigheid beperkt. Temperatuurveranderingen zijn goed waarneembaar, maar de nauwkeurigheid om een absolute temperatuur te meten is beperkt. In dit project is de warmtebeeld camera (Flir T530) gebruikt. Deze camera heeft een niet geheel homogene temperatuurgevoeligheid over zijn pixelgebied (320x240). Dit is vooral zichtbaar in foto's met een gering temperatuurcontrast. Zie foto gemaakt in de koelcel in Figuur 34. Het aantal graden 
afwijking dat dat lokaal oplevert is afhankelijk van het temperatuurniveau. Voor toepassing rond de $0^{\circ} \mathrm{C}$ loopt de afwijking in het donkerblauwe gebied op tot een afwijking tot ongeveer $3^{\circ} \mathrm{C}$.

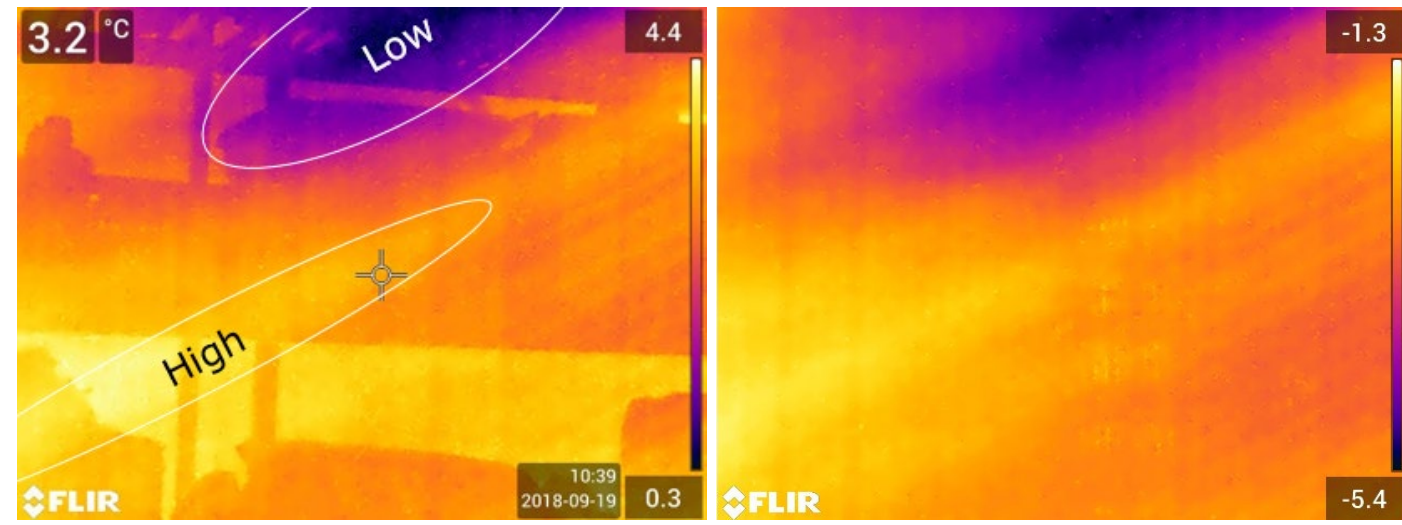

Figuur 34: IR-foto gemaakt in koelcel WFBR met Flir T530.

In bewaarcellen van hardfruit wordt de verdamper zo geselecteerd dat deze maximaal gebruik maakt van de gehele breedte van de cel. Het is daarom veelal niet mogelijk om IR-beeldopnames te maken van de temperatuurverdeling van bochten van de circuitbuizen die aan de zijkant zitten.

\subsubsection{Uitvoering}

Om met metingen vast te stellen of alle circuits gelijkwaardig meedoen en hoe goed de verdamper/luchtkoeler de korte krachtige koelactie kan realiseren is er gekozen voor de volgende uitvoering:

a) Maken van een infrarood filmopname (elke 10s een opname) van voorzijde (lucht uittredende zijde) over de gehele hoogte van de koeler. Zie rode kader in Figuur 35.

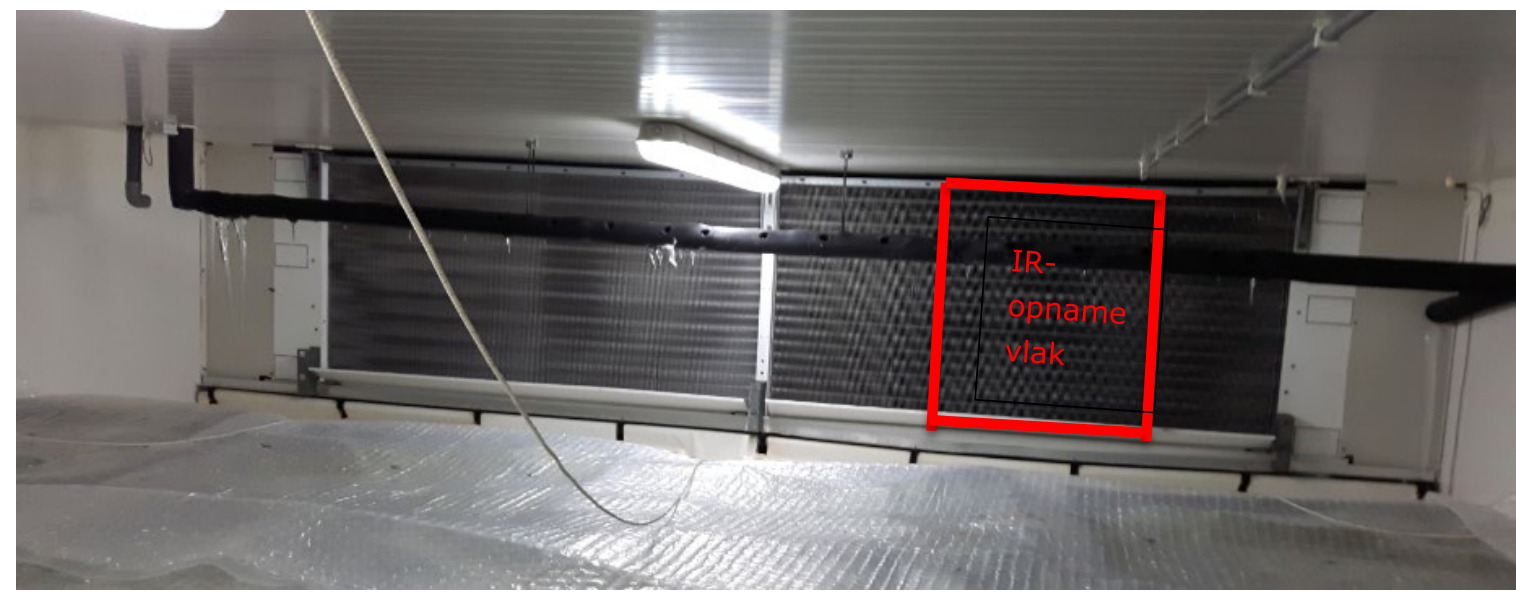

Figuur 35: Meetvlak van IR-foto opnames over de gehele hoogte koeler.

De IR-opname levert een groot aantal thermische foto's. Om deze beelden om te zetten in getallen of grafieken is er een programma ontwikkeld om uit de foto een bovenste en onderste deel van de verdamper te selecteren en hiervan de gemiddelde temperatuur te berekenen. De gemiddelde temperatuur wordt berekend op basis van de individuele pixeltemperaturen. Figuur 36 is een voorbeeld hoe een bovenste en onderste helft van de verdamper digitaal uit de foto worden geselecteerd. 


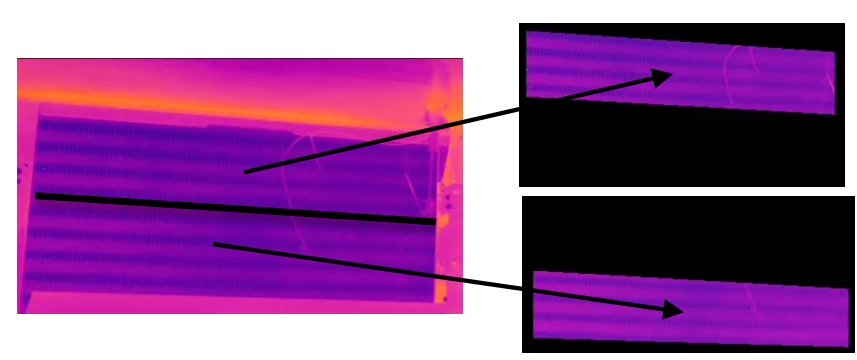

Figuur 36: Digitale selectie van het bovenste- en onderste deel van de verdamperoppervlak voor berekening van de gemiddelde oppervlaktetemperatuur.

De keuze om de data uit te werken in een bovenste en onderste helft van de verdamper is gebaseerd op het feit dat het bij een verticale circuitconfiguratie dan mogelijk is om te controleren of een circuit over de volledige lengte stabiel functioneert.

b) Meten van de lucht in- en uittredetemperatuur in het midden van het IR-meetvlak door plaatsen van temperatuurvoelers (Figuur 37).

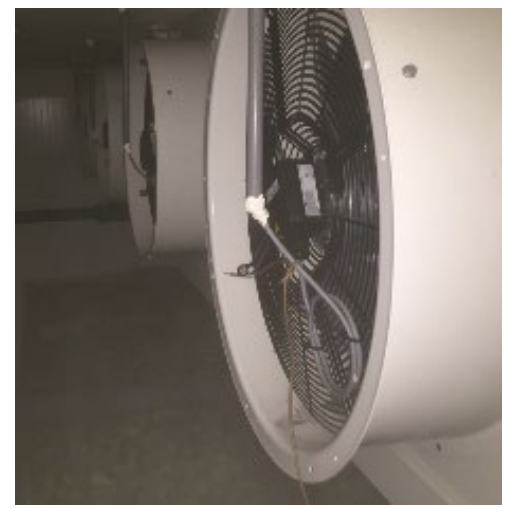

Figuur 37: Meten van lucht intredetemperatuur aan de ventilatorzijde.

c) Meten van de circuittemperaturen:

- In de diepte richting (bijvoorbeeld voorste-, middelste- en achterste circuit bij pompsysteem)

- In de hoogte richting (bijvoorbeeld: intrede circuit, 1/3 circuitlengte, 2/3 circuitlengte, uittrede circuit bij pompsysteem)

- Aanvoer en retour temperatuur naar verdamper.

Zie rode punten voor de meetposities in Figuur 38.

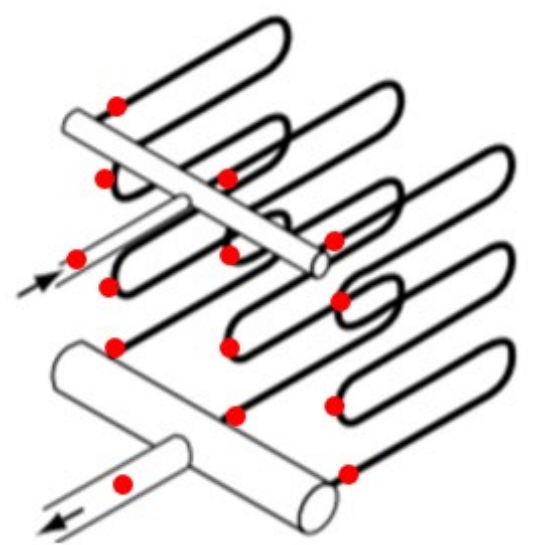

Figuur 38: Voorbeeld van de positionering van de meetpunten voor het meten van de circuittemperaturen bij een pompsysteem. 
Om de reactiesnelheid van het koelsysteem vast te leggen is het nodig om moment van de meting (klok) van alle systemen vast te leggen of te synchroniseren. Het gaat dan om de volgende systemen:

- $\quad$ klok van besturingssysteem koeling (start en stop tijdstip van koelactie en ontdooiacties)

- klok IR-camera

- klok logger van temperaturen

- (klok camera)

In de praktijk is er met 20 thermokoppels gemeten. De combinatie van de metingen $a, b$ en $c$ geeft een volledig beeld van de werking van koeler.

\subsubsection{Nauwkeurigheid en reactietijd temperatuurmetingen}

Met het meten met thermokoppels is het van belang dat de reactiesnelheid en nauwkeurigheid van de thermokoppels bekend zijn. Er is een reactiesnelheid gemeten middels onderdompeling in ijswater en er is meerdere malen met ijswater de nauwkeurigheid (de afwijking bij $0^{\circ} \mathrm{C}$ ) bepaald. De metingen zijn weergegeven in de onderstaande Figuur 39 en Figuur 40.

De reactiesnelheid varieert in de orde van $1 \mathrm{~s}$ tot $5 \mathrm{~s}$. De afwijking bij $0^{\circ} \mathrm{C}$ is voor de eerste 13 kanalen tussen -0.1 en $-0.3^{\circ} \mathrm{C}$, maar opvallend is dat deze daarna merkwaardig oploopt tot $0.62^{\circ} \mathrm{C}$ van kanaal 20 .

Samenvattend is de meting voldoende snel en is de opmerkelijk verlopende nulafwijking van de meetkanalen gelukkig stabiel zodat de meetdata hiervoor gecorrigeerd kan worden.

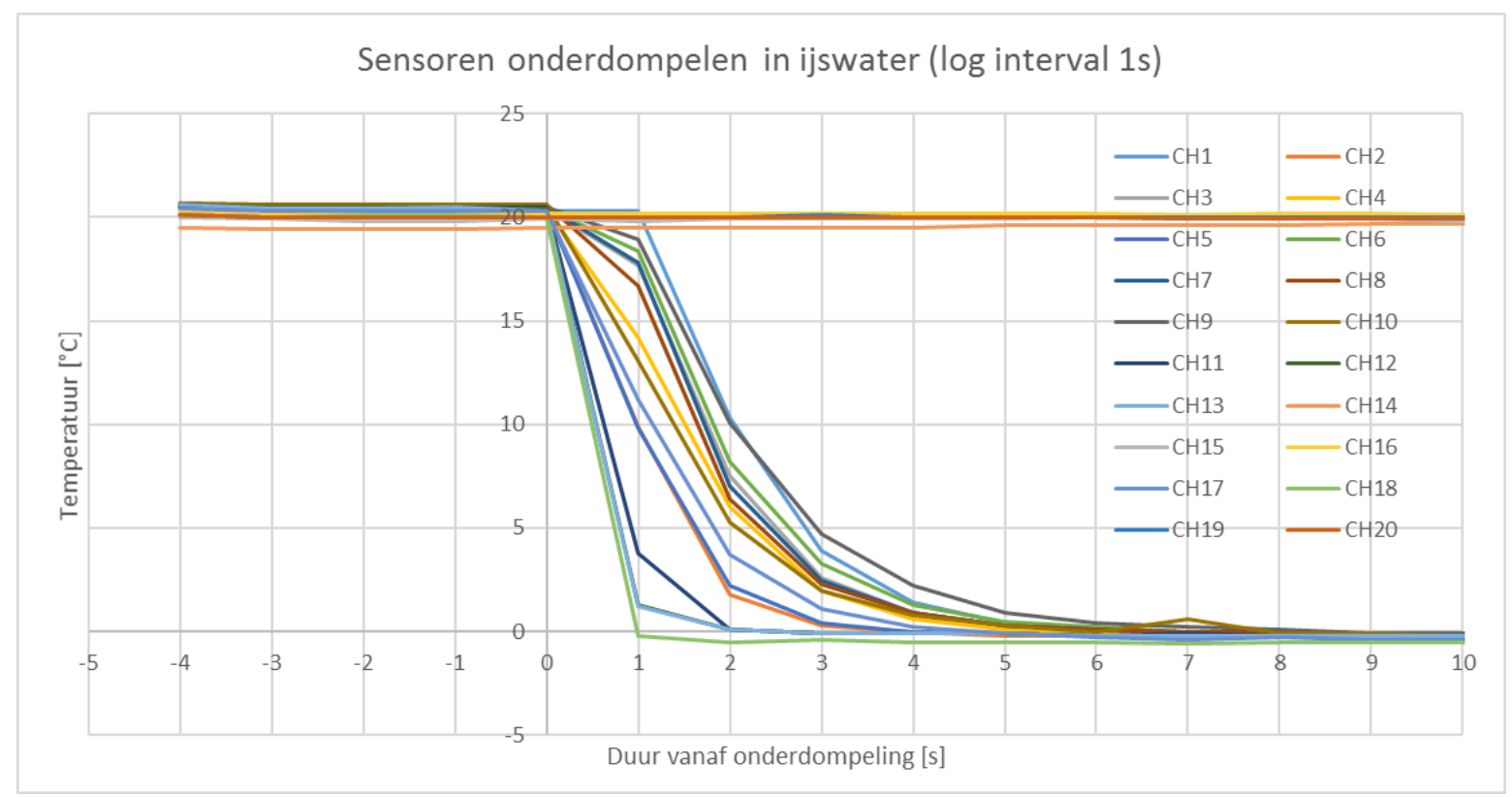

Figuur 39: Reactiesnelheid van de temperatuurmeting per meetkanaal. 


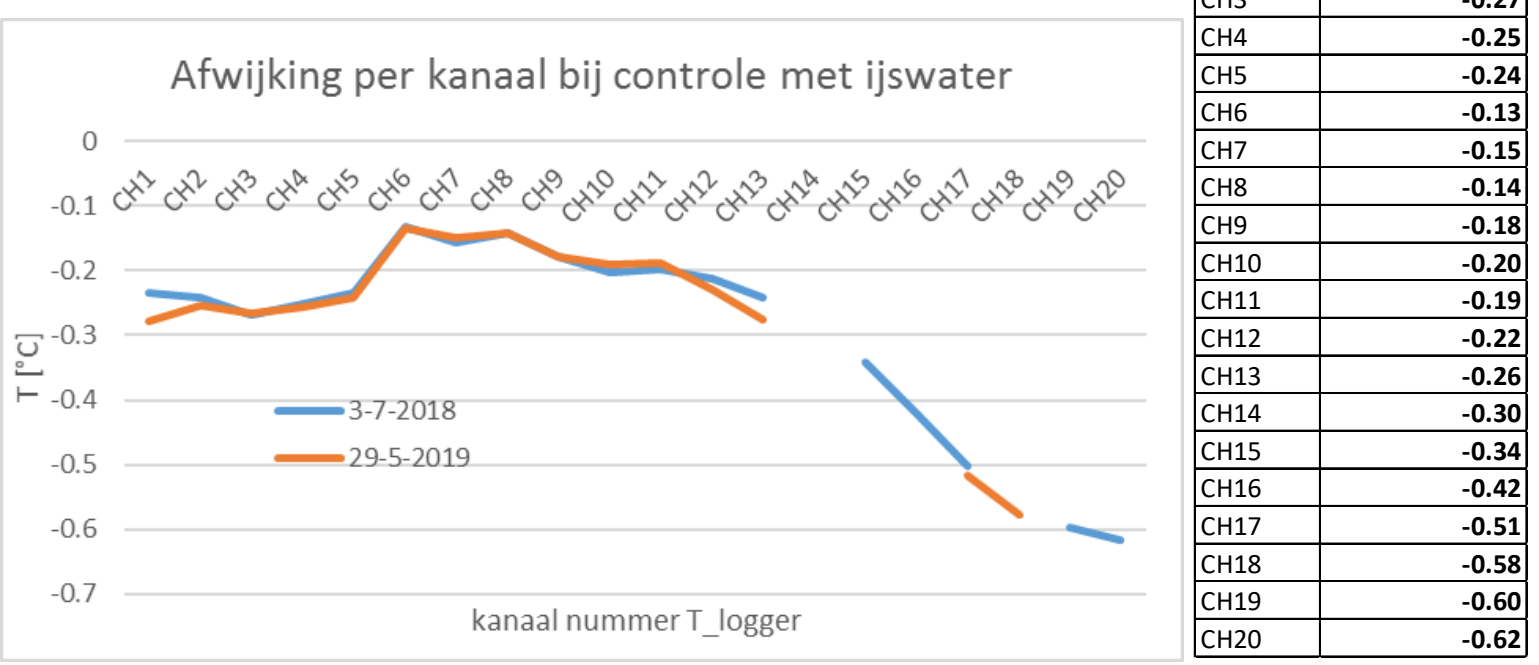

Figuur 40: Controle nulpuntafwijking van meetkanalen middels roeren in ijswater per meetkanaal.

\subsection{Resultaten}

\subsubsection{Analyse over alle uitgevoerde metingen}

In Tabel 8 is een overzicht weergegeven van de uitgevoerde metingen op verschillende locaties van verschillende type koelsystemen. Vraag is of de metingen, die onder sterk verschillende omstandigheden gemeten zijn (zie opmerkingen), onderling goed vergelijkbaar zijn.

Tabel 8: Overzicht van de uitgevoerde metingen op verschillende locaties van verschillende koelsystemen

\begin{tabular}{|c|c|c|c|c|c|}
\hline $\mathrm{Nr}$ & Datum & Locatie & Type systeem & $\begin{array}{l}\text { To } \\
{\left[{ }^{\circ} \mathrm{C}\right]}\end{array}$ & Opmerking \\
\hline 1 & $2018-5-25$ & $\begin{array}{l}\text { Locatie A } \\
\text { systeem } 1\end{array}$ & $\mathrm{NH}_{3}$-pomp & -9 & Volle cel bloemen \\
\hline 2 & $2018-6-7$ & Locatie B & $\mathrm{CO}_{2}$-pomp & -9 & Lege cel, kleine testcel \\
\hline 3 & $2018-7-4$ & Locatie C2 & $\mathrm{NH}_{3}$-pomp & -6 & lege cel \\
\hline 4 & $2018-8-29$ & Locatie D & $\mathrm{NH}_{3}$-pomp & -10 & lege cel \\
\hline 5 & $2018-9-4$ & Locatie C1 & $\mathrm{NH}_{3}$-pomp & -10 (niet stabiel) & lege cel, inslagperiode \\
\hline 6 & $2018-9-5$ & $\begin{array}{l}\text { Locatie A, } \\
\text { systeem } 3\end{array}$ & $\mathrm{NH}_{3}$-pomp & -8.5 & Volle perencel, inslagperiode \\
\hline 7 & $2018-11-9$ & $\begin{array}{l}\text { Locatie A, } \\
\text { systeem } 1\end{array}$ & $\mathrm{NH}_{3}$-pomp & -9 & Volle perencel \\
\hline 8 & 2018-11-9 & $\begin{array}{l}\text { Locatie A, } \\
\text { systeem } 2\end{array}$ & Glycol & $?$ & $\begin{array}{l}\text { Volle perencel } \\
\text { Geen ruimte voor thermokoppels metingen }\end{array}$ \\
\hline 10 & 2019-10-1 & Locatie E & 404A DX & -10.5 & Volle perencel \\
\hline 11 & $2019-10-2$ & Locatie F & $\mathrm{CO}_{2} \mathrm{DX}$ & -11 & Werkruimte, dubbel uitblazende koeler \\
\hline
\end{tabular}

Doel van de metingen is om de koelacties met elkaar te vergelijken. Wat je wilt zien bij een "goede" koelactie is een snelle en duidelijke temperatuurdaling na de start van een koelactie, opgevolgd door een min of meer stabiele temperatuur van het koelerblok van enkele minuten en een snelle stijging 
van de temperaturen na het stoppen van de koelactie. Een dergelijke typische koelactie is weergegeven in Figuur 41.

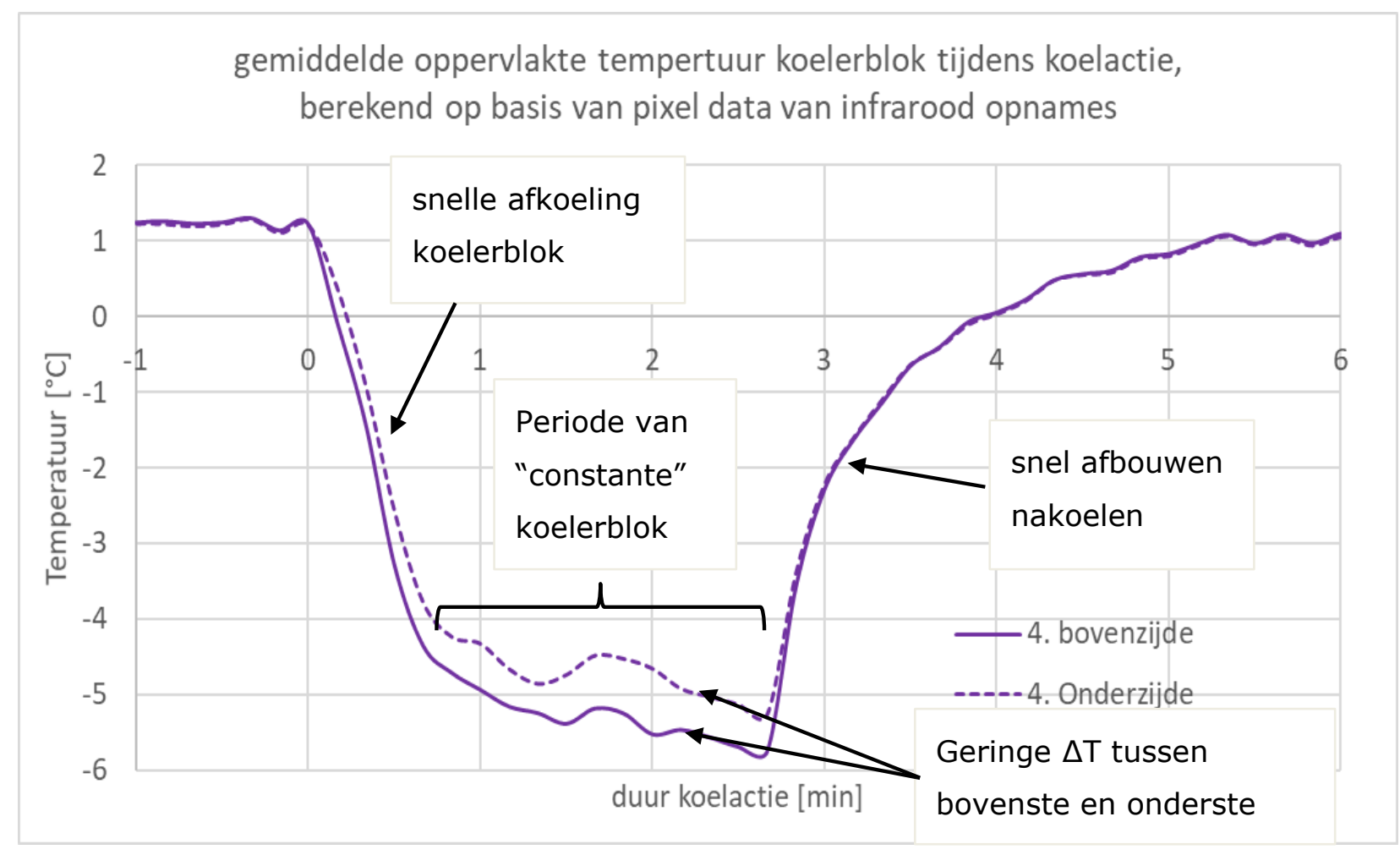

Figuur 41: Voorbeeld van bloktemperatuur ontwikkeling bij een korte en krachtige koelactie.

Figuur 42 geeft een overzicht van de gemeten gemiddelde oppervlaktetemperatuur van de koelacties bij 8 verschillende locaties.

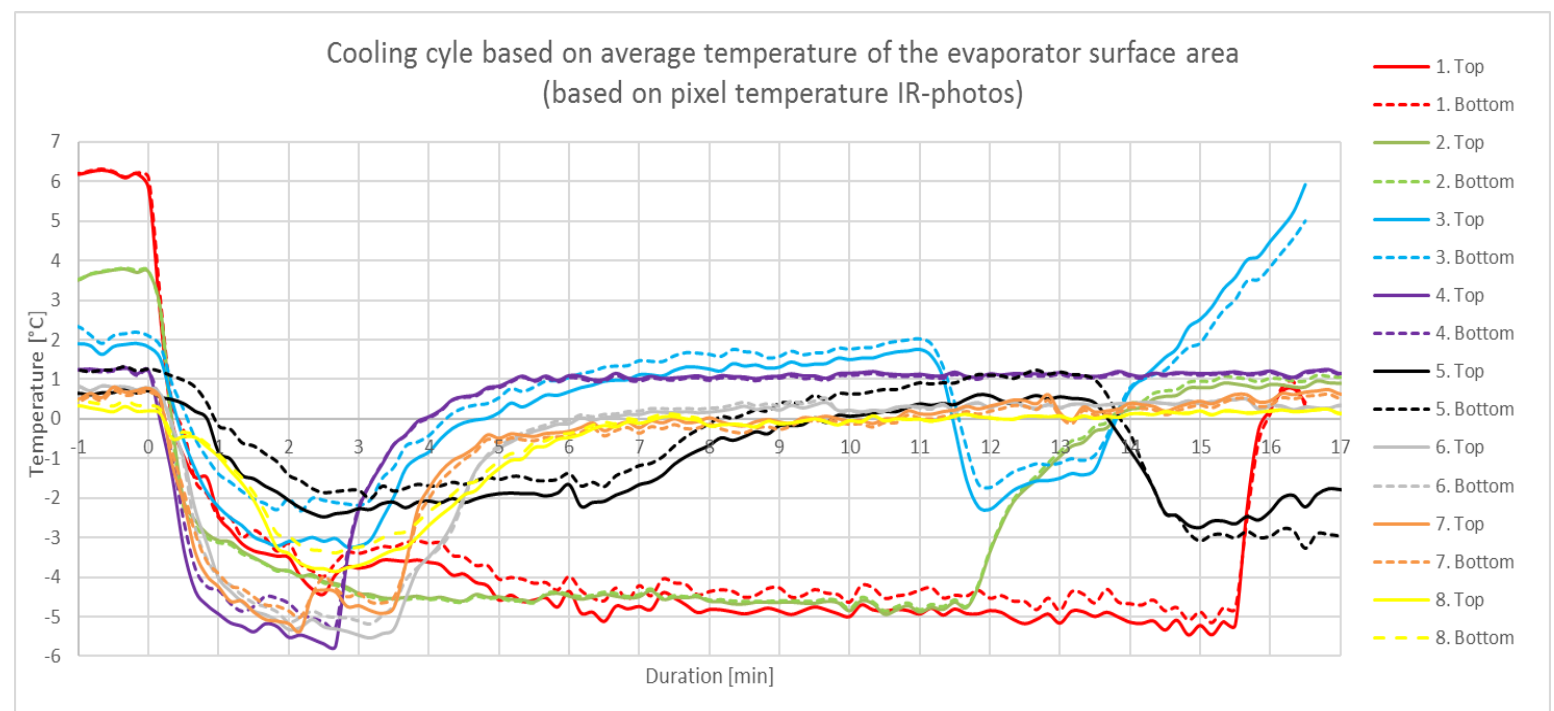

Figuur 42: Gemeten gemiddelde bloktemperaturen tijdens een koelactie van bovenste (dichte lijn) en onderste (gestippelde lijn) helft van het verdamperoppervlak.

Korte toelichting per meting:

- Ad 1 rood. Dit betreft een langere koelactie bij een verhoogd setpoint, vanwege de hoge warmtebelasting van nog niet op temperatuur zijnde bloemen. Er is sprake van een duidelijke en snelle start en stop van de koelcyclus.

- Ad 2 groen. Er is sprake van een duidelijke en snelle start van de koelactie, maar de beëindiging is langzaam. Er is duidelijk sprake van een zogenaamd na-koeleffect. De langere cyclus is het gevolg van een relatief kleine verdamper in de testcel. 
- $\quad$ Ad 3 licht blauw. Er is sprake van een relatief langzame start en stop van de koelactie. Daarbij is de daling van de lameloppervlaktetemperatuur beperkt, wat te verklaren is door de relatief hoog ingestelde zuigdruk/verdampingstemperatuur. De onderzijde van het blok wordt duidelijk minder koud dan de bovenzijde (Figuur 43). De achterblijvende temperatuur aan de onderzijde wordt waarschijnlijk veroorzaakt door een te geringe en instabiele hoeveelheid ammoniak. Waarschijnlijk is hier sprake van een 'top feed'-verdeling van het koudemiddel.
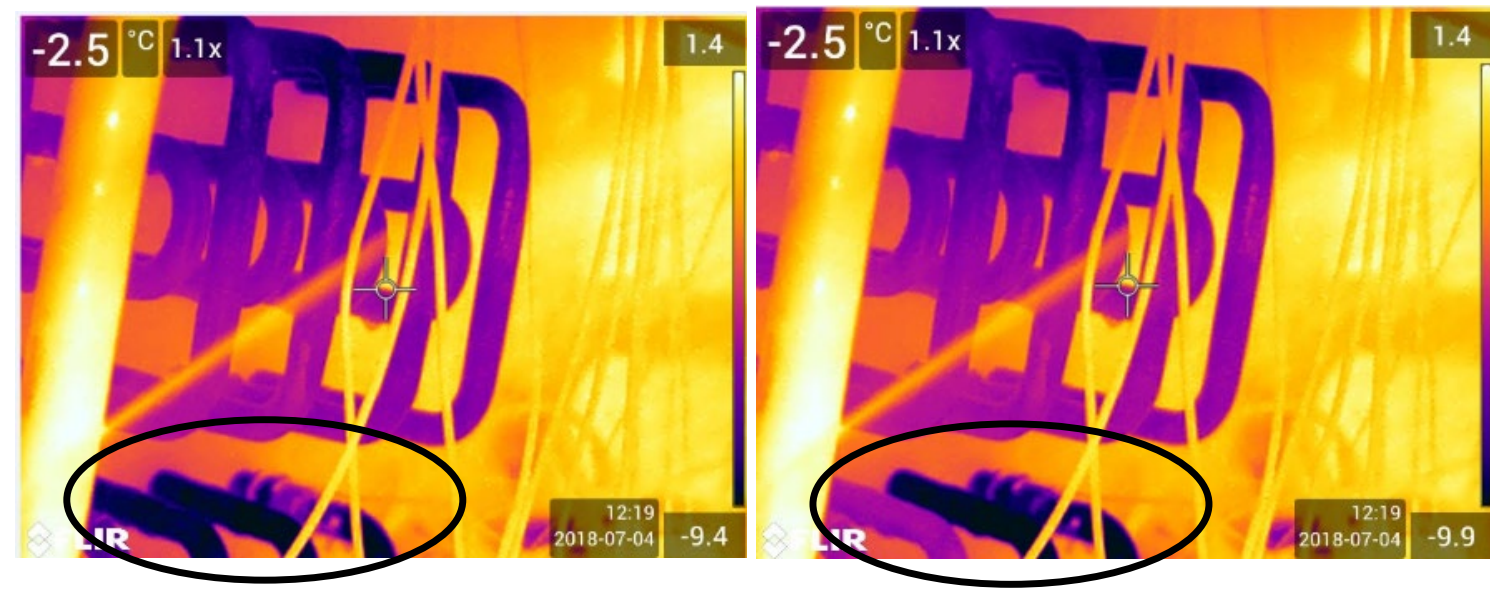

Figuur 43: Twee opeenvolgende IR-foto's van de zijkant van het blok waaruit de instabiliteit aan de onderzijde van het blok blijkt (in cirkels: dikke leidingen die van kleur veranderen).

- Ad 4 paars. Er is sprake van een duidelijke en snelle start en stop van de koelactie. Dit wordt deels veroorzaakt door de relatief lage zuigdruk van $-10^{\circ} \mathrm{C}$.

- Ad 5 zwart. Zeer onduidelijke en trage start en stop van de koelactie. Dit wordt deels veroorzaakt door de sterk schommelende en sterk verhoogde zuigdruk (Figuur 44) door het overbelaste koelsysteem.

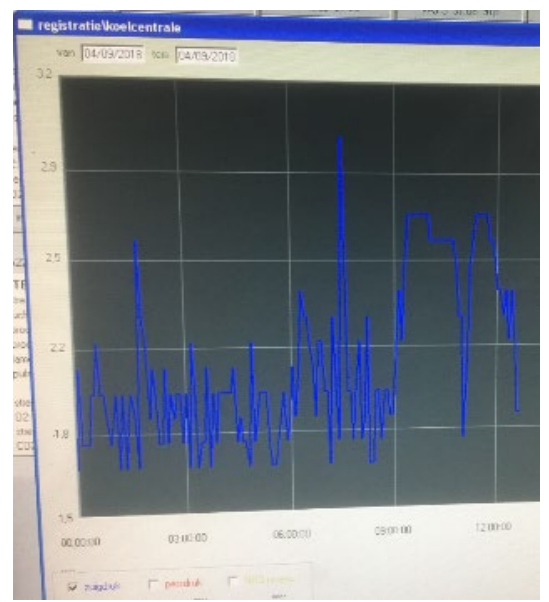

Figuur 44: Foto van scherm van sterk wisselende zuigdruk.

- Ad 6 grijs. Er is sprake van een duidelijke en snelle start maar de stop van de koelactie is minder snel.

- Ad 7 oranje. Er is sprake van een duidelijke en snelle start en stop. Stabiele koelfase is minder stabiel.

- Ad 8 geel. Koelactie met langzame start en stop. Dit is verklaarbaar, omdat het een glycolkoeler betreft. 


\subsubsection{Nut van combineren van meettechnieken}

Omdat er bij koelerblokmeting nummer 3 voldoende ruimte was om ook IR-opnames van de zijkant van de koeler te maken, zijn er drie metingen gedaan:
a) IR-opnames voorzijde verdamper
b) IR-opnames zijkant verdamper
c) Circuittemperaturen verdamper

Figuur 45 en Figuur 46 laten een direct vergelijk zien van de circuittemperaturen op basis van de IRfoto's en de gemeten waardes met thermokoppels op de buizen. Wat in beide type metingen opvalt, is dat de onderste deel van de circuits niet temperatuurstabiel is. Doorbladeren van alle IR-foto's laat dit nog beter zien. Zie onderstaande afbeeldingen die exact op de minuut geselecteerd zijn (Figuur 45).
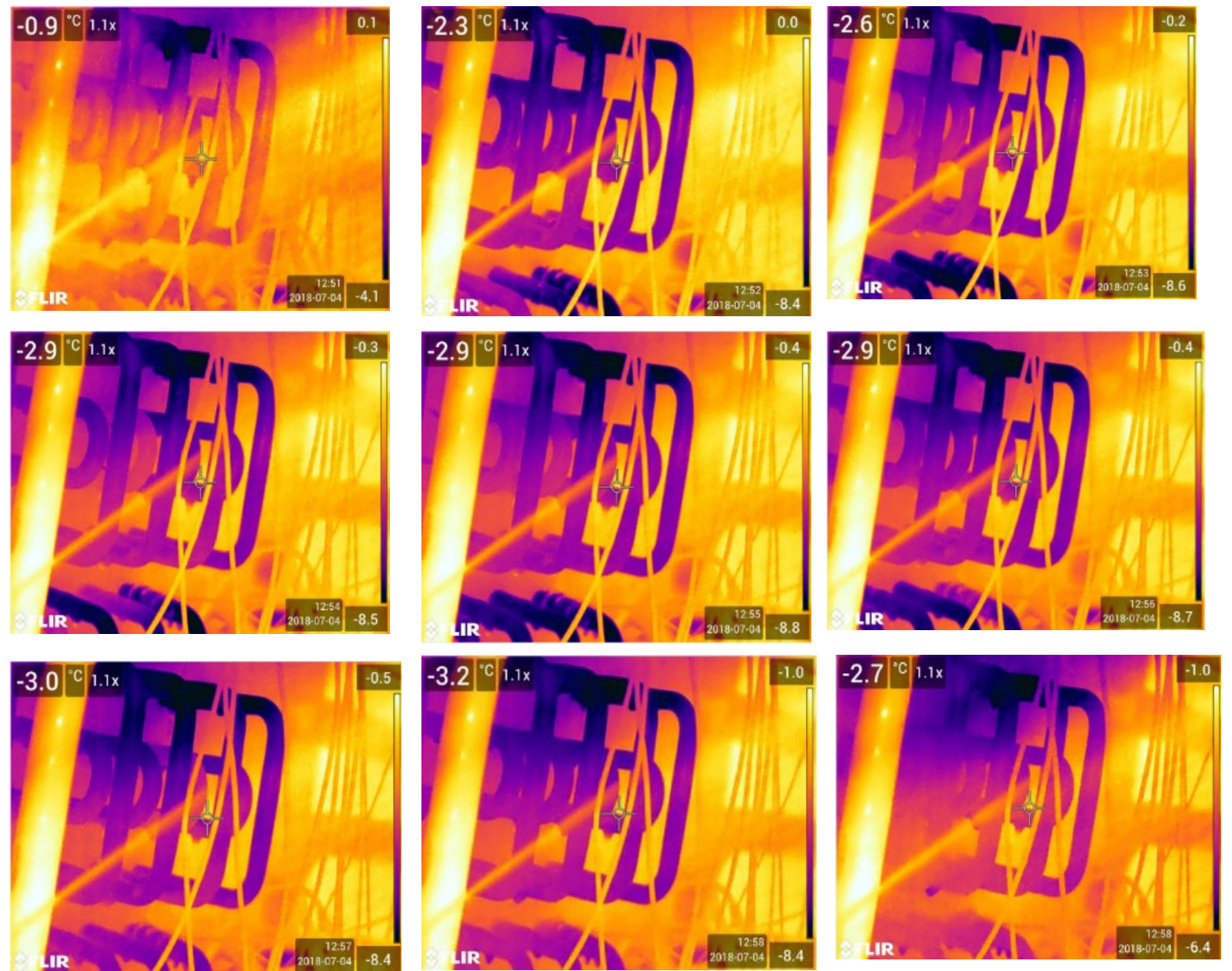

Figuur 45: IR-foto's van gemeten buistemperaturen van koelactie gestart op 10:51 (tijd van camera wijkt 2 uur af) ((linksboven) tot en met 10:58 (rechtsonder). 

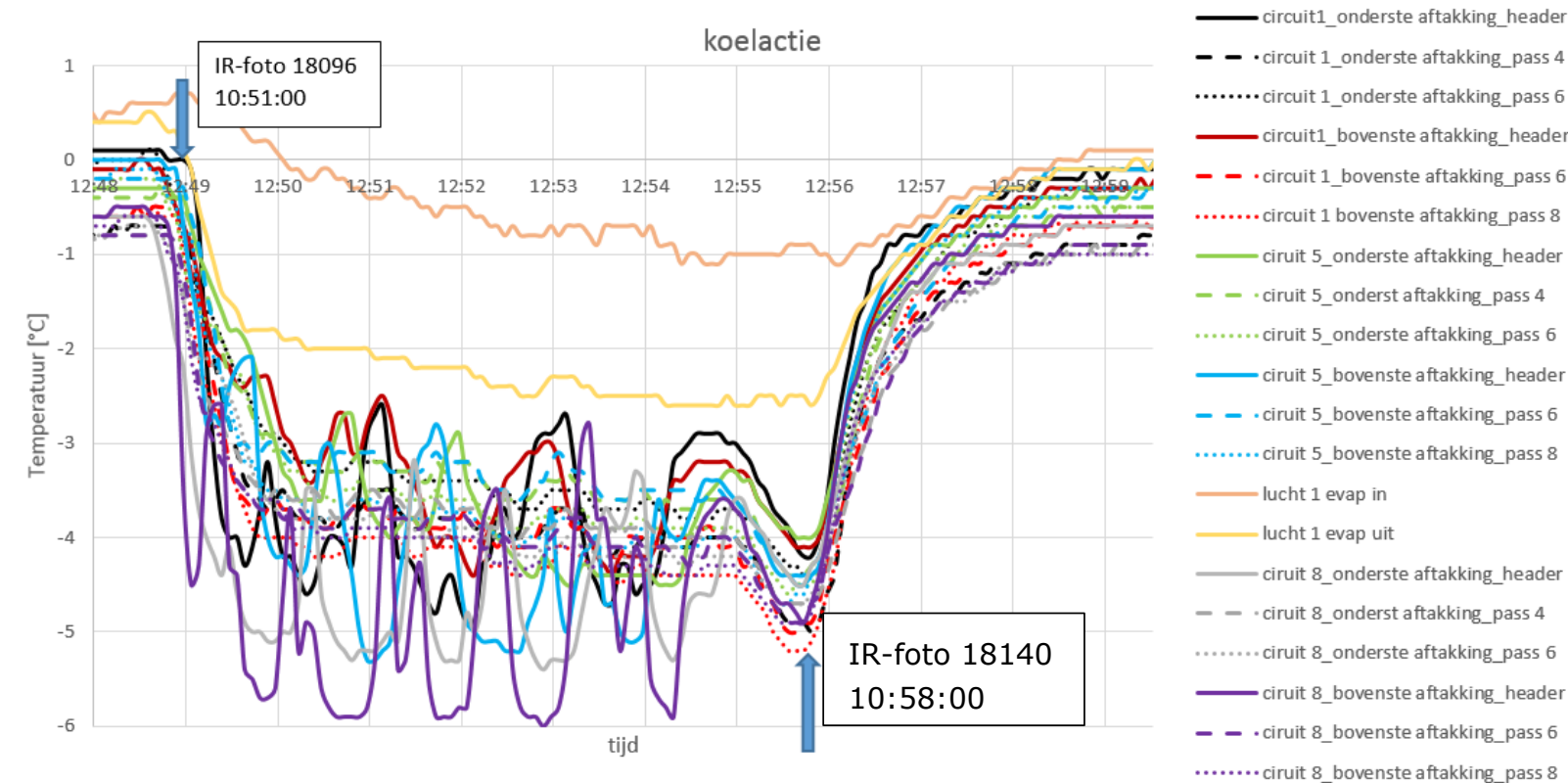

Figuur 46: Gemeten buistemperaturen van koelactie gestart op 10:51.

In Figuur 47 en Figuur 48 is de relatie te zien tussen de IR-foto's van de voorzijde van het koelblok en de gemeten circuittemperaturen. Wat in beide type metingen opvalt, is dat het onderste deel van de circuits niet temperatuurstabiel is. Doorbladeren va de IR-foto's laat nog duidelijker zien dat delen van de circuits aan de onderzijde van het blok soms oplopen in temperatuur om daarna weer koud worden.
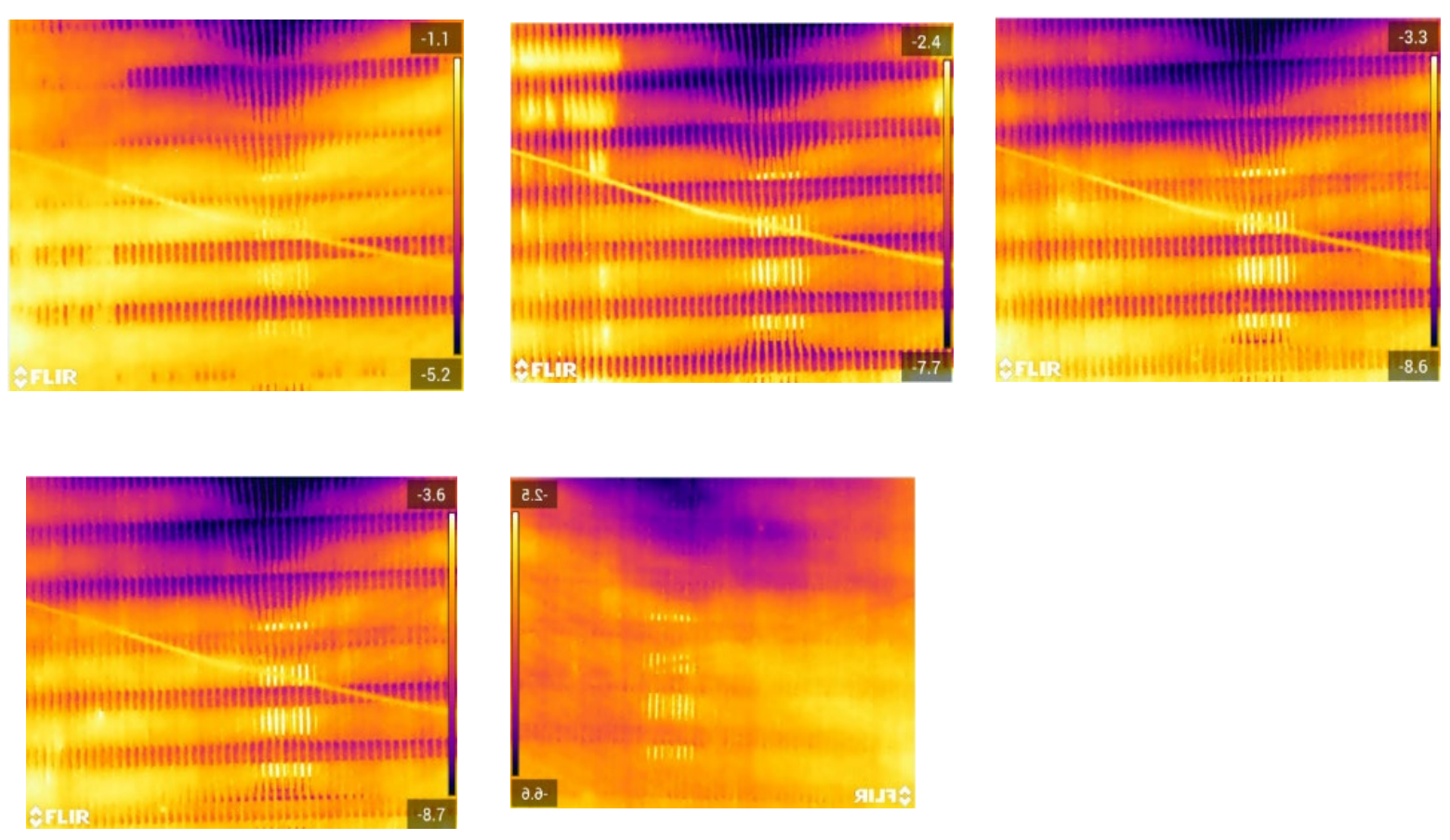

Figuur 47: IR foto's van gemeten buistemperaturen van koelactie gestart op 10:51 met interval van 10 s. 

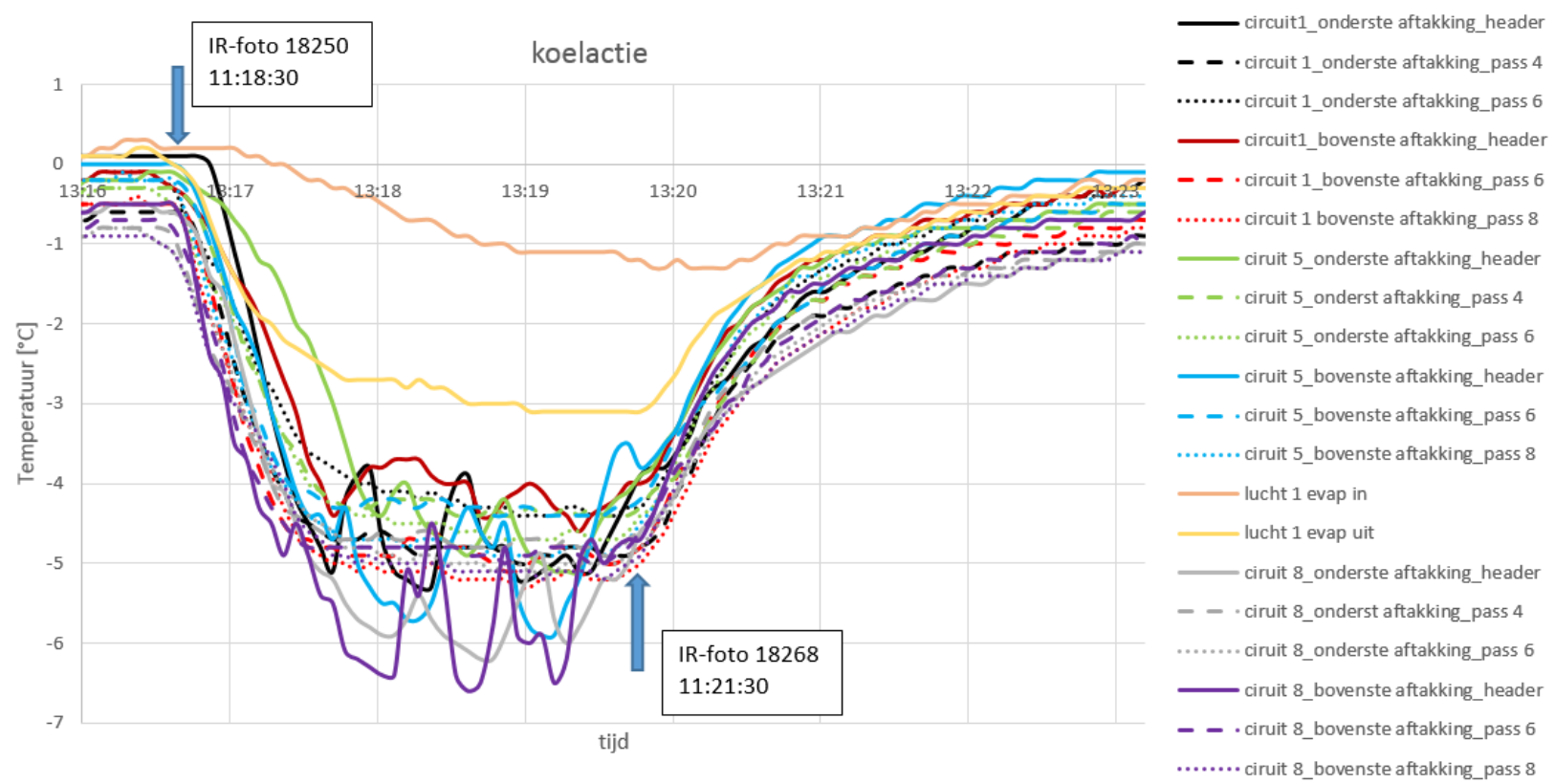

Figuur 48: Gemeten buistemperaturen van koelactie gestart op 11:18:30.

\subsubsection{Temperatuurmetingen van $\mathrm{NH}_{3}$-pompsysteem in volle bewaarcel (meting 7)}

Doel is het focussen op een meting van een volle perencel om te kijken of de temperatuurmetingen van de IR-foto's en de fysieke buistemperatuurmetingen overeenkomen en voldoende betrouwbaar zijn.

In Figuur 49 zijn alle fysieke temperatuurmetingen weergegeven aangevuld met de gemiddelde bloktemperatuur berekend op basis van de foto's van de IR-camera. Daaruit blijkt dat de temperaturen van de IR-camera globaal goed overeenkomen met de gemeten buistemperaturen (de donkere oranje lijnen). De buistemperaturen zijn met een tijdinterval van 5 seconden gemeten en de IR-foto's met een tijdsinterval van $10 \mathrm{~s}$ (=minimum waarde camera).

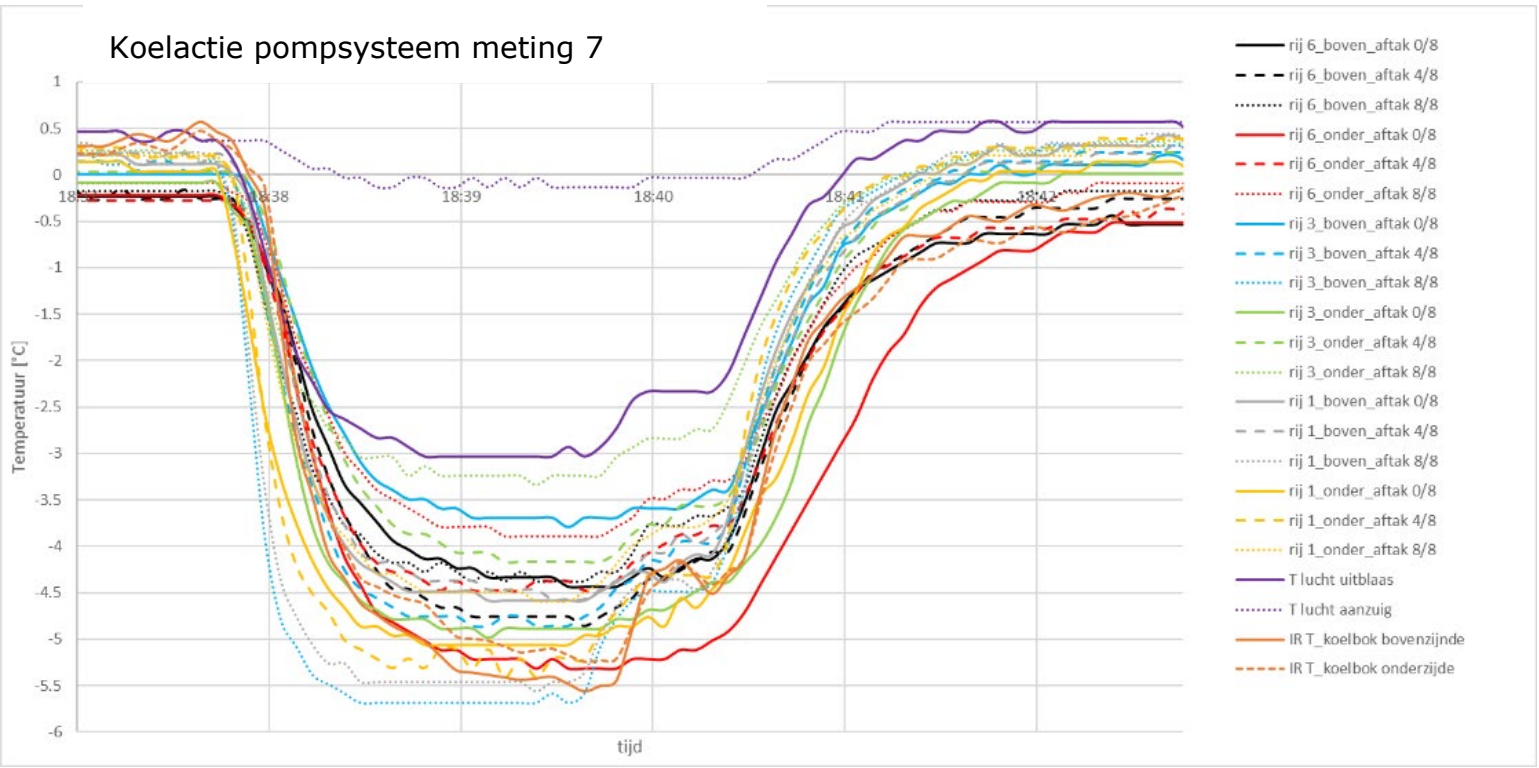

Figuur 49: Metingen van een koelactie van een $\mathrm{NH}_{3}$ pompsysteem met een volle cel peren.

Wanneer enkel de lijnen met dezelfde rijnummer worden bekeken, bijvoorbeeld rij 3, dan vallen de volgende zaken op (Figuur 50).

a) Afwijking van $0.4^{\circ} \mathrm{C}$ van de sensoren, ondanks nulpuntcorrectie met ijswater.

b) Onverklaarbare afwijking van vloeistofintredetemperatuur tussen onderste en bovenste aftakking van de header van $1.3 \mathrm{~K} .0 \mathrm{~K}$ wordt hier verwacht. 
c) Onverklaarbaar verschil van de temperatuurontwikkeling in de onderste en bovenste circuits (zijn zelfs tegengesteld). Hier worden een min of meer gelijke trendverloop verwacht.

d) Het is ook opmerkelijk dat er binnen een circuit relatief grote temperatuurverschillen worden gemeten. Dit omdat een pompsysteem gevoed wordt met een overmaat aan vloeistof en de interne drukval over de circuits klein is (ontwerpparameter verdamper).

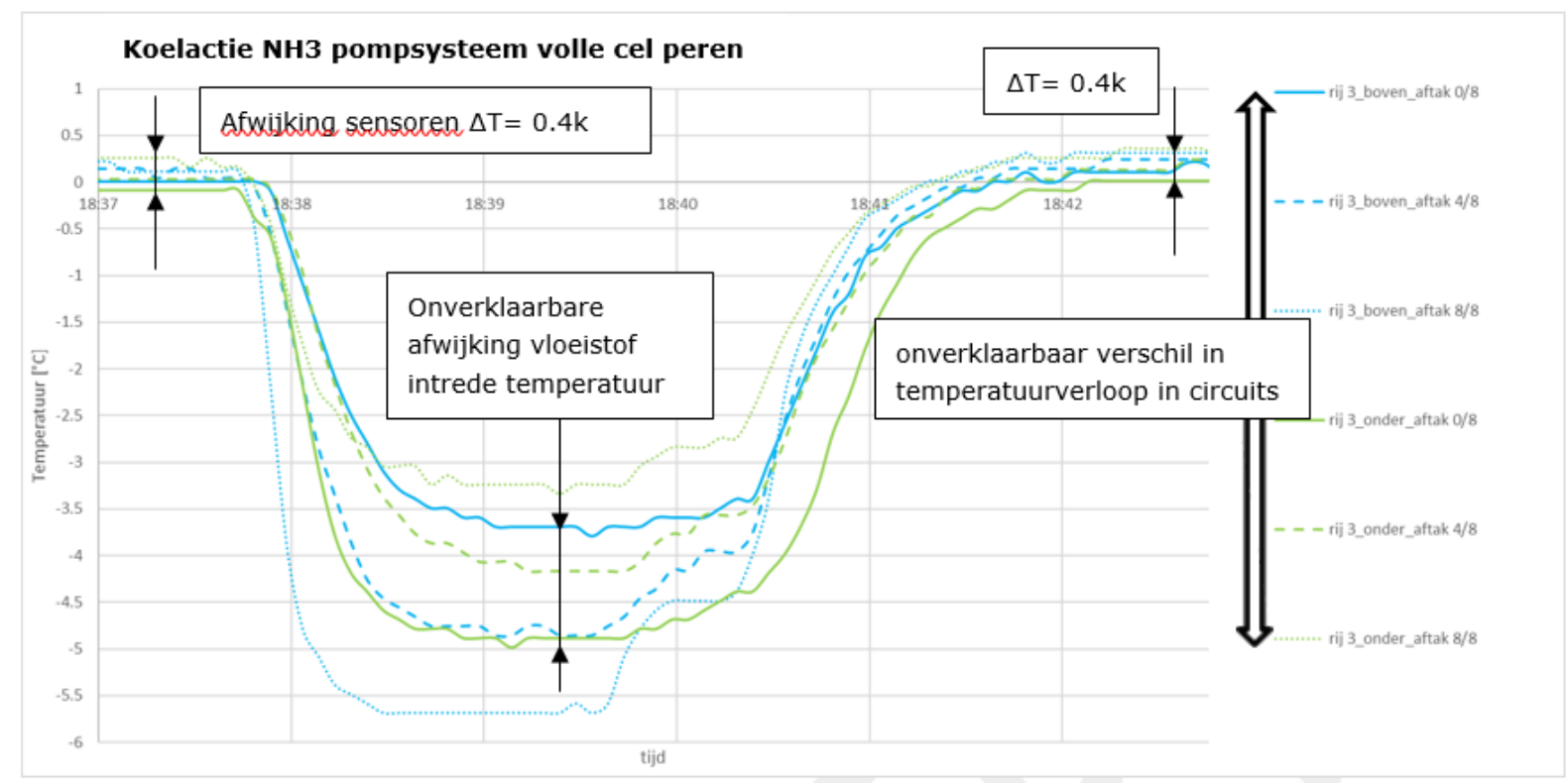

Figuur 50: Detail van de circuittemperatuurontwikkeling van rij 3 (luchtzijdig, het midden van de koeler) bij een koelactie van een $\mathrm{NH}_{3}$-pompsysteem met een volle cel peren.

\subsubsection{Temperatuurmetingen van R404A DX-systeem in volle bewaarcel}

De onderstaande grafiek (Figuur 51) is een koelactie van een R404A DX systeem, waarbij de koeler is voorzien van een zuigklep (Danfoss CVQ -klep). De koelactie is niet kort en krachtig (duur

10 minuten) en is niet stabiel. Na 4 minuten is er een vloeistof tekort/verdeel probleem, waardoor het koelend vermogen beperkt is. Dat de koelactie niet stabiel is, is ook al duidelijk te herkennen aan de registratie van de blokvoeler in het besturingssysteem (Figuur 52). Op basis van een enkele meting kan niet geconcludeerd worden dat een DX-systeem niet geschikt is om een korte krachtige koelactie te maken, maar feit is dat bij een DX-systeem een koelactie minder stabiel is dan een pompsysteem. Advies is om in elk geval de stabiliteit te controleren op basis van systeem registratie zoals blokvoeler.

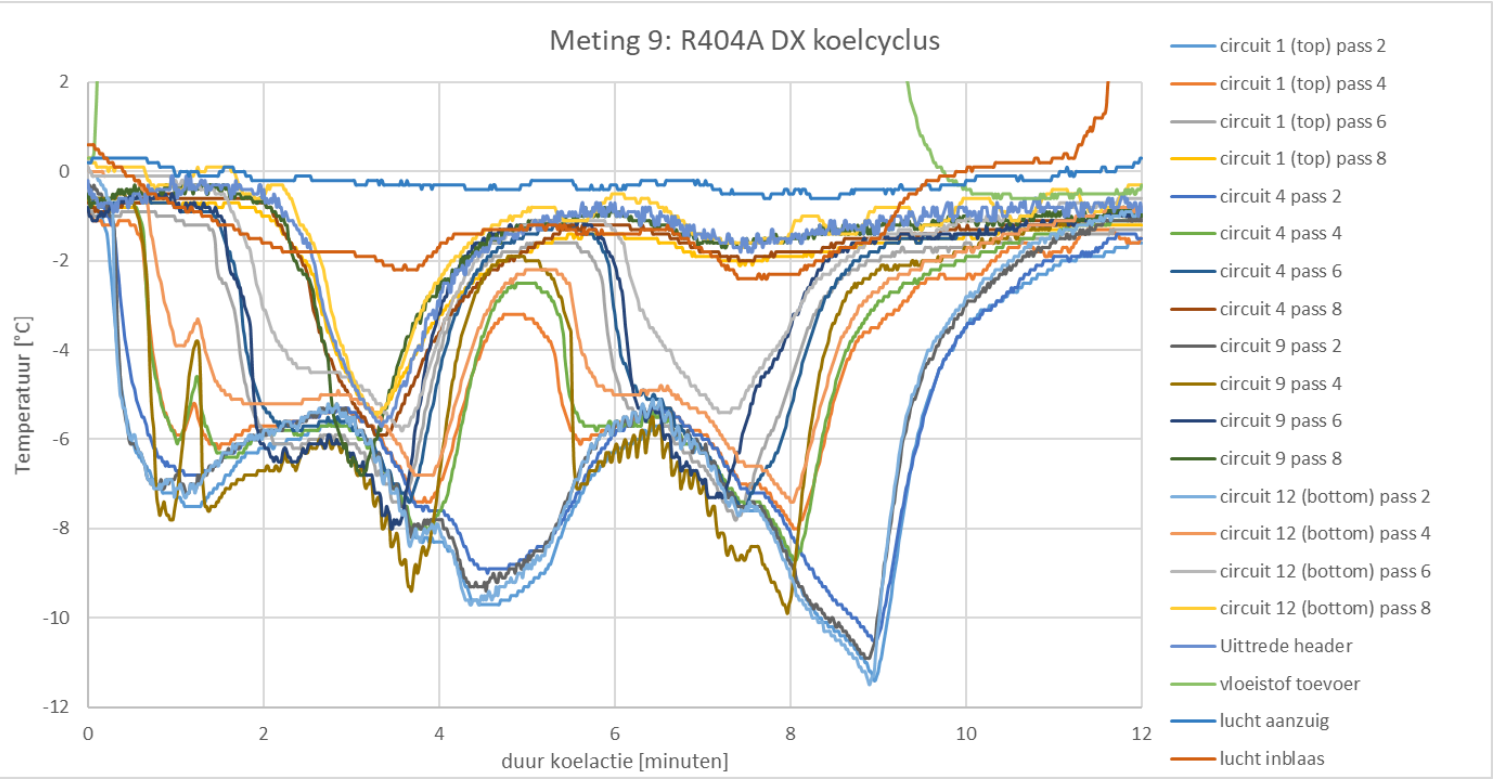

Figuur 51: Metingen van circuit en luchttemperatuur van koelactie gestart om 14:47. 


\section{Cel 20}

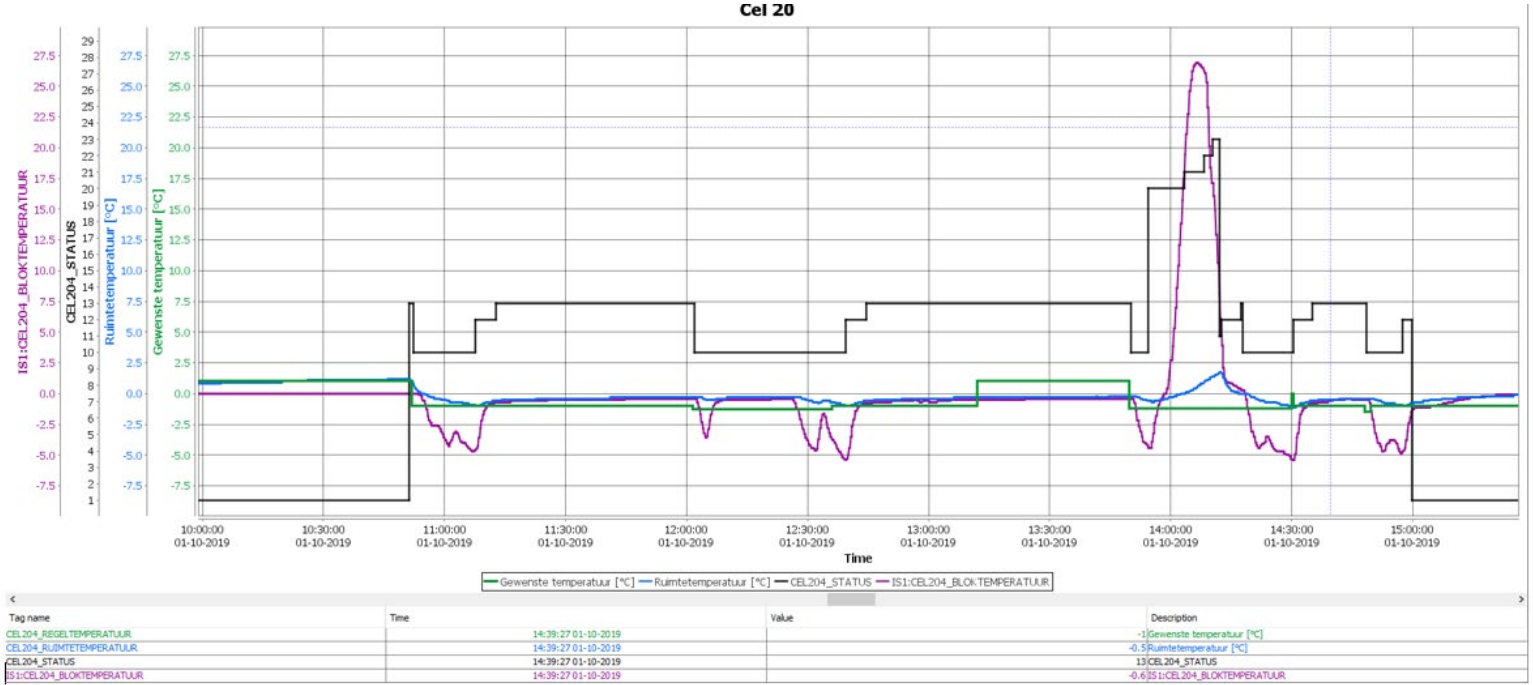

Figuur 52: Overzicht van koelacties en ontdooiing. Op basis van blokvoeler is al duidelijk dat koelacties niet stabiel zijn. De koelactie van 14:47 is de laatste koelactie.

\subsubsection{Temperatuurmetingen van $\mathrm{CO}_{2} \mathrm{DX}$-systeem in transportcel}

De onderstaande grafiek (Figuur 53) is een koelactie van een dubbel uitblazende koeler in een transportcel. Het gaat hier dus niet een korte/krachtige koelactie in een perencel, maar om een koelactie van twee parallel werkende dubbel uitblazende koelers in een transportcel. Tijdens de koelactie, die ruim 15 minuten duurt, wordt de lucht in de ruimte afgekoeld van 6.5 naar $2.0^{\circ} \mathrm{C}$. De koelactie ziet er stabiel uit, wat ook blijkt uit de afkoeling van de lucht die continu tussen de 3 tot $4 \mathrm{~K}$ zit.

Omdat het type koeler sterk afwijkt van een fruitkoeler, kan geen conclusie getrokken worden of een $\mathrm{CO}_{2}$-DX systeem geschikt voor kort krachtige koelactie in perenbewaring.

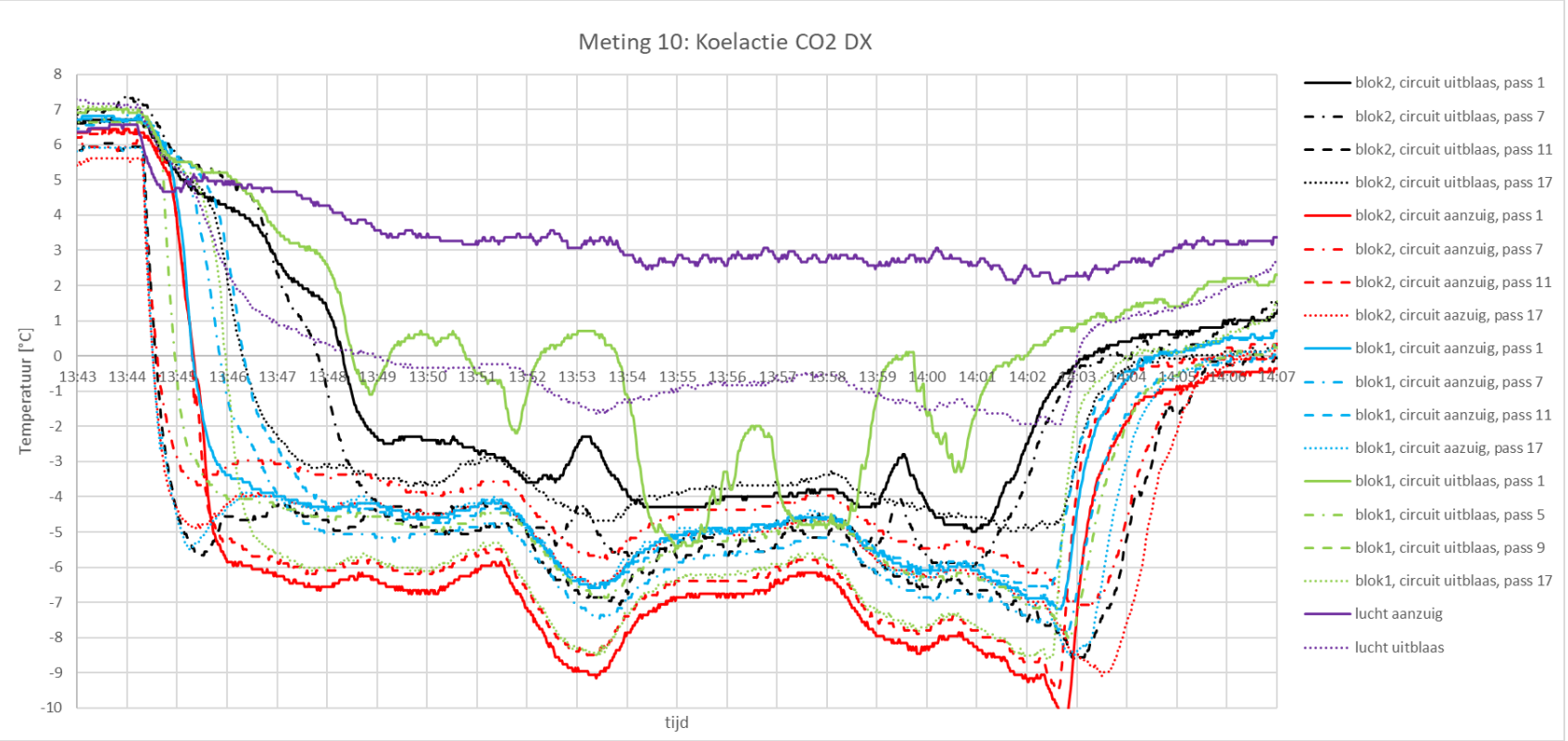

Figuur 53: Koelactie een dubbeluitblazende koeler in een transportcel. Installatie is van het type $\mathrm{CO}_{2} \mathrm{DX}$. 


\subsection{Conclusies/discussie en planning}

Er zijn een 10-tal meetsessies uitgevoerd waarvan 6 maal een ammoniakpompsysteem, 1x R404a DX, $1 \times 1 \mathrm{CO}_{2}$-pompsysteem, $1 \times \mathrm{CO}_{2}$-DX en 1 glycolpompinstallatie. Ook is er gemeten bij verschillende condities, volle en lege cellen en bij stabiele en minder stabiele zuigdrukken. Ondanks het beperkt aantal testen per systeem is duidelijk dat een glycolsysteem duidelijk minder snelle en krachtige koelacties maakt dan een ammoniakpompsysteem. Het geteste $\mathrm{CO}_{2}$-pompsysteem is in een lege testcel getest. Qua startsnelheid van de koelactie komt deze dicht in de buurt van een ammoniakpompsysteem, maar had meer last van een na-koeleffect aan het einde van de koelactie. Of dit veroorzaakt wordt door de eigenschappen van $\mathrm{CO}_{2}$ zelf en/of de uitvoering van de verdamper, kan op basis van deze meting niet bepaald worden. Daarvoor zijn meer metingen nodig, liefst in een praktijkcel vol met peren. Van de twee DX systemen was die meting met R404a niet stabiel en niet krachtig. Dit had ook herkend kunnen worden aan de niet stabiele temperatuurverloop van de blokvoeler. De $\mathrm{CO}_{2}$-DX koeler functioneerde goed maar was een dubbeluitblazende koeler in een transportruimte. Er kan daarom geen uitspraak gedaan worden of een $\mathrm{CO}_{2}$-DX systeem ook geschikt is voor korte krachtige koelacties. Koelacties van DX systemen zijn niet vanzelfsprekend stabiel en krachtig.

Ondanks de beperkte nauwkeurigheid van een IR-camera voor het meten van de absolute temperatuur, geeft deze wel goed en duidelijk de temperatuurveranderingen weer. Vaste stabiele oververhitting van een circuit is lastiger waar te nemen dan een schommeling van de temperatuur door instabiel gedrag. IR-opnames van de zijkant van een koeler geven meer informatie dan van de voorzijde. Het zou dus mooi zijn, als ondanks de vaak beperkte ruimte tussen koeler en de wand, er toch opnames vanaf de zijkant gemaakt zouden kunnen worden.

Meten van circuittemperaturen met temperatuurvoelers (in dit geval thermokoppels) op de circuits lijkt een nauwkeurige manier van meten, maar de nauwkeurigheid van de resultaten valt echter tegen. Een klein deel van de afwijking is te verklaren door de beperkte nauwkeurigheid van de sensoren, maar een groot deel van de afwijkingen kan niet verklaard worden. Feit is dat het aanbrengen van thermokoppels op de leiding met tape onvoldoende lijkt, omdat er onverklaarbare temperatuurverschillen zijn gemeten in de vloeistof intredetemperatuur van circuits die op dezelfde positie van de vloeistofheader zitten. Wenselijk is om de temperatuur in de leiding te meten en liefst ook nog de druk op dezelfde posities. Dit is in praktijk niet mogelijk als een koeler daarvoor niet speciaal af-fabriek is geprepareerd. Vraag is in hoeverre nauwkeurige resultaten zijn te behalen als er speciale nauwkeurige en thermisch geïsoleerde voelers op de buizen worden ontwikkeld en geïnstalleerd.

Ook wil je uitsluiten dat het resultaat beïnvloed wordt door andere omstandigheden. Meest representatief is een meting van een koelactie van een volle koelcel die automatisch gestart wordt vanuit de estafette-regeling. 


\section{Conclusies en aanbevelingen}

Binnen het project Humistatus is naar vele aspecten gekeken die te maken hebben met de humistatus van peren en hoe hier zo optimaal mogelijk in de na-oogst fase mee om te gaan om vochtgerelateerde problemen zoals slappe nekken en rot te kunnen beperken/voorkomen. De vele resultaten en nieuwe inzichten leveren de volgende conclusies en aanbevelingen op voor de praktijk en vervolgonderzoek:

\section{Meetmethoden en modellen om gevoeligheid Conference peren voor slappe nekken en vochtverlies te voorspellen:}

- Het voorspellen van de gevoeligheid van partijen 'Conference' peren (direct na de oogst) om slappe nek te ontwikkelen, kan op basis van brons, nekvorm en grootte. Met behulp een gestandaardiseerde cameraopstelling met analyse software kunnen monsters peren middels een enkele non-destructieve meting worden geanalyseerd voor brons, grootte en vorm. Het ontwikkelde model stelt bedrijven in staat om de gevoeligheid voor slappe nekken van partijen 'Conference' peren te voorspellen en hun bewaarstrategieën hierop af te stemmen. Verder onderzoek wordt aangeraden om het huidige model te versterken, nieuwe modellen te genereren voor aangepaste bewaarcondities en praktijkgerichte objectieve meetmethoden door te ontwikkelen.

- Uitwerking en validatie van het voorlopige model voor bepaling van relatieve gevoeligheid van herkomsten voor vochtverlies op basis van brons en brix biedt perspectief. Zeker in lijn met de ontwikkelingen op het vlak van verbetering van NIR-modellen voor ${ }^{\circ}$ Brix en watergehalte van peren (Mishra et al., 2021; Mishra et al., 2021). Een integratie van een cameraopstelling voor brons en NIR voor Brix zou het mogelijk maken om deze non-destructieve meting in 1 handeling te doen.

\section{Meetmethoden om real time inzicht te hebben in de ontwikkeling van het gewichtsverlies op kritische plaatsen in de cel:}

- Een afstandmeting op basis van ultrasoontechnologie lijkt een goede potentiele sensor voor het rechtstreeks meten van gewichtsverlies in bewaring. De techniek leent zich voor doorontwikkeling naar een sensorsysteem op kistniveau (verkleining, IoT datamanagement) om zo op verschillende posities in de bewaarcel het gewichtsverlies te kunnen monitoren.

- Real-time en draadloos meten Temperatuur (T) en Relatieve luchtvochtigheid (RV) op verschillende locaties in de cel geeft geen betrouwbare eenduidige relatie tussen de gemiddelde gemeten $\mathrm{T}$ en RV en het gewichtsverlies per kist. Toevoeging van lokale luchtsnelheidsmetingen zou hier mogelijk verbetering in kunnen brengen. Echter dit is lastig te realiseren.

Maatregelen tijdens teelt/inslag/bewaring om vochtgerelateerde problemen te beperken:

- Het telen van peren met de juiste vruchteigenschappen lijkt de basis voor strakke peren na lange bewaring. Een uniformer product aan de boom (vruchtmaat, brons) geeft minder variatie in vochtafgifte tijdens bewaring. Vochtverlies beperkende maatregelen tijdens bewaring zijn hierop slechts aanvullend.

- Aangezien partijen in verschillende mate reageren op maatregelen is een goede inschatting van de gevoeligheid op slappe nekken van de partij belangrijk om te kunnen sturen op getallen in de bewaring.

- Binnen de praktische mogelijkheden kan door het uitsluiten van een langere periode ongekoeld (nacht), het vochtverlies worden beperkt. Het oogstmoment in de ochtend zorgt mogelijk ook voor minder vochtverlies.

- Het snel bereiken van de eind bewaartemperatuur is belangrijk om zowel het vochtverlies als ook de risico's op (late) inwendig bruin te beperken. Traag inkoelen kan tot een $10 \%$ relatief extra vochtverlies leiden, vergelijkbaar met een vochtverlies van 1-2 maanden bewaring. Het trager inkoelen (voorzichtiger) geeft ook extra risico op late bruinontwikkeling, al blijkt dit wel sterk afhankelijk van herkomst. 
- De mate waarin slappe nekken ontwikkelen is partijspecifiek, maar de invloed van de positie in de cel op het optreden van slappe nekken is echter zeker zo groot. Het is dus belangrijk om waarnemingen van zowel gewichtsverlies als slappe nekken te relateren aan de positie in de cel. Dit geldt ook voor de aansturing van vochtverliesbeperkende maatregelen.

- De vochtverliesverdeling lijkt in veel cellen een gelijk patroon te volgen. Veel verlies dicht onder de verdamper en op vloer niveau. Het laagste gewichtsverlies in de uitblaas van de verdamper. Het netto gewichtsverlies kan binnen een cel met een factor 2 tot zelfs 4 verschillen. Dompelen geeft een basisverlaging van het vochtverlies en lijkt juist ook de verdeling binnen de cel te verbeteren. Door inzicht in de verschillen in vochtverlies binnen een cel zal een verder streven naar het uniformeren van het celklimaat ontstaan. Dit in plaats van het streven naar een gemiddeld lager vochtverliesniveau.

- Keuze voor het type fust is in relatie tot beperking vochtverlies volgens de resultaten uit het project niet van belang. Wel moet gelet worden op hygiëne van de kisten: schimmelige kisten kunnen leiden tot aanzienlijk meer schimmeldoorontwikkeling.

- Als het product door een vochtiger klimaat in vochtverlies beperkt moet worden, kan dit beter over het gehele seizoen gebeuren dan dat in de laatste periode nog een hoge vochtigheid wordt aangelegd. Dit onderzoek toont aan dat juist het aanleggen van hoge vochtigheid in de laatste fase van de bewaring tot meer rotontwikkeling kan leiden.

- Het tijdig herkennen van kwaliteitsrisico's zoals ook het late inwendige bruin is zowel op herkomst als jaarniveau zeer wenselijk. Het resultaat uit dit onderzoek draagt drogestofgehalte van een partij aan als parameter om mee te nemen bij ontwikkeling van een voorspellingsmodel voor laat bruin. Ontwikkelingen in meetmethoden, zoals Nabij Infra Rood (NIR)-technologie zullen bijdragen aan het vereenvoudigen van metingen van o.a. droge stof en daarmee de kans op toepassing in de praktijk (Mishra et al., 2021; Mishra et al., 2021).

\section{Dynamisch gedrag koeler:}

- Inzicht in de werking van de koeler draagt bij aan een optimaal celklimaat. De koelacties hebben invloed op het vochtverlies en temperatuur/vochtverdeling in de cel. Uit de metingen aan diverse koelers die in dit project uitgevoerd zijn, blijkt dat niet alle koelers de koelacties maken zoals men verwacht. Dit kan verschillende oorzaken hebben. In het project is een quickscan tool ontwikkeld, een vragenlijst waarmee snel een beeld gekregen kan worden van eventueel afwijkend koelergedrag en mogelijke oorzaken, door het beantwoorden van een aantal vragen. De vragen gaan o.a. over het temperatuurverschil tussen warmste en koudste celpositie, de hoeveelheid ontvochtiging en het aantal koelminuten. Bij afwijkende waarden worden er een aantal verdiepende vragen gesteld. Het verdient aanbeveling deze tool verder te ontwikkelen en te toetsen in de praktijk. Door meerdere waarnemingen aan elkaar te koppelen kan het ook als een benchmarktool dienst gaan doen. Om specifieker een beeld te krijgen van de kwaliteit van een koelactie kunnen koelermetingen op basis van infraroodmetingen met warmtebeeldcamera meer detailinformatie geven en mogelijke oorzaken van afwijkingen vinden. 


\section{$7 \quad$ Referenties}

Brouwer B, Geijn Fvd, Hogeveen E, Maas Rvd, Verschoor J, Wissink E, Wild Hd (2019) Resultaten experimenten Humistatus 2017-2019: Tussenrapportage Werkgroep Peer. In. Wageningen Food \& Biobased Research, Wageningen

Geijn Fvd, Schaik Av, Verschoor J (2006) Bewaring van Conference: Bewaarhandleiding: onderzoeksresultaten van het KwaliCon-project en bestaande kennis gebundeld. In WUa Research, ed. Nederlandse Fruittelers Organisatie, Zoetermeer

Konarska A (2013) The relationship between the morphology and structure and the quality of fruits of two pear cultivars (Pyrus communis L.) during their development and maturation. TheScientificWorldJournal 2013: 846796-846796

Lara I, Belge B, Goulao LF (2014) The fruit cuticle as a modulator of postharvest quality. Postharvest Biology and Technology 87: 103-112

Mishra P, Marini F, Brouwer B, Roger JM, Biancolillo A, Woltering E, Hogeveen-van Echtelt E (2021) Sequential fusion of information from two portable spectrometers for improved prediction of moisture and soluble solids content in pear fruit. Talanta $\mathbf{2 2 3}$

Mishra P, Woltering E, Brouwer B, Hogeveen-van Echtelt E (2021) Improving moisture and soluble solids content prediction in pear fruit using near-infrared spectroscopy with variable selection and model updating approach. Postharvest Biology and Technology 171

Nguyen TA, Verboven P, Daudin J-D, Vandewalle S, Nicolaï BM (2004) Effect of picking date, time and temperature on water sorption of 'Conference' pear tissue. Postharvest Biology and Technology 33: 243-253

Nguyen TA, Verboven P, Daudin JD, Nicolaï BM (2004) Measurement and modelling of water sorption isotherms of 'Conference' pear flesh tissue in the high humidity range. Postharvest Biology and Technology 33: 229-241

Nguyen TA, Verboven P, Scheerlinck N, Vandewalle S, Nicolaï BM (2006) Estimation of effective diffusivity of pear tissue and cuticle by means of a numerical water diffusion model. Journal of Food Engineering 72: 63-72

Nguyen TA, Verboven P, Schenk A, Nicolaï BM (2007) Prediction of water loss from pears (Pyrus communis cv. Conference) during controlled atmosphere storage as affected by relative humidity. Journal of Food Engineering 83: 149-155

Scharwies JD, Grimm E, Knoche M (2014) Russeting and Relative Growth Rate Are Positively Related in 'Conference' and 'Condo' Pear. HortScience horts 49: 746-749

Wertheim SJ (1990) De peer. In Mededeling/Proefstation voor de Fruitteelt, Vol Nr. 22. Proefstation voor de Fruitteelt, Wilhelminadorp 


\section{Bijlage 1. Grafieken T en RV meting}
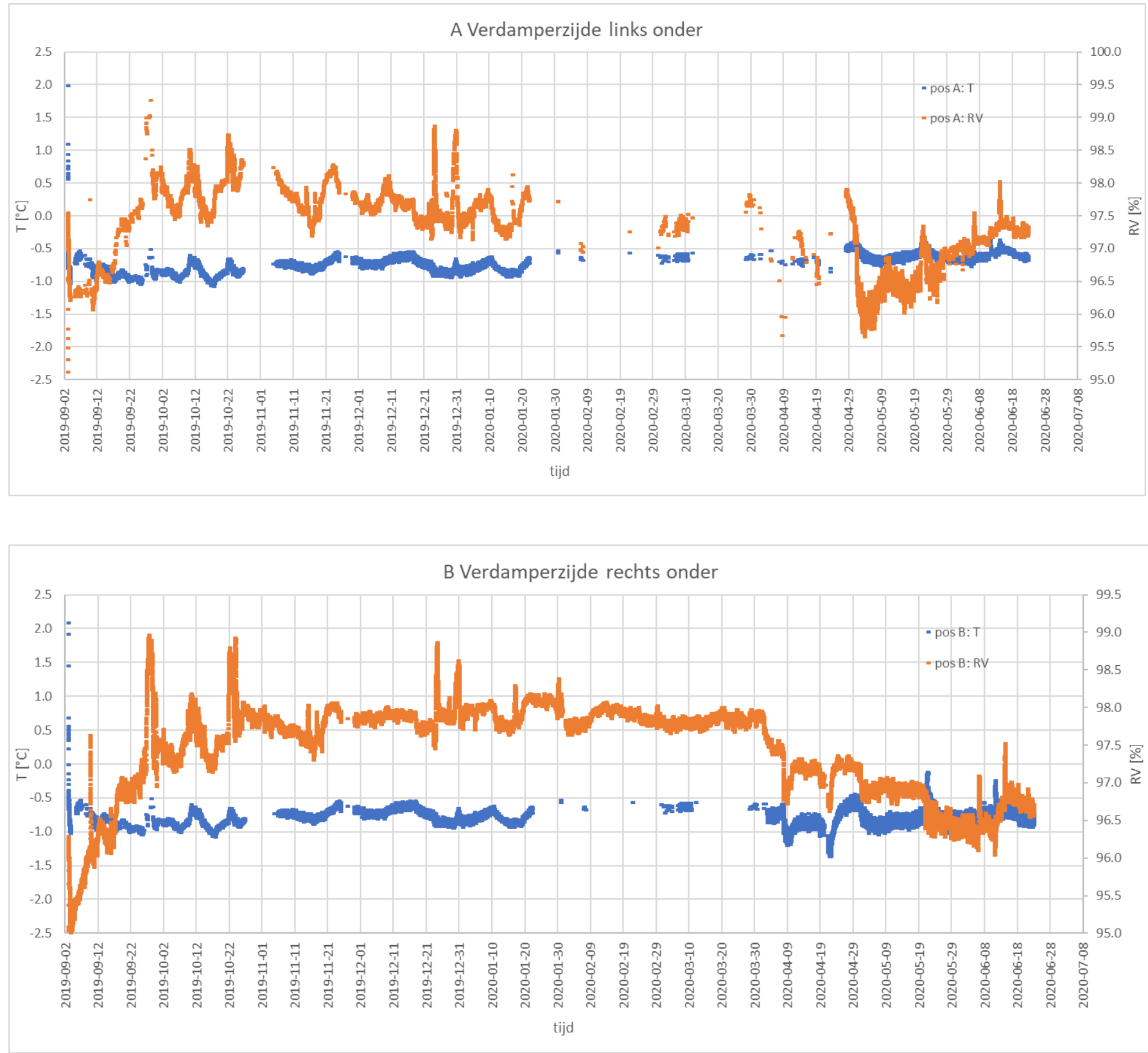

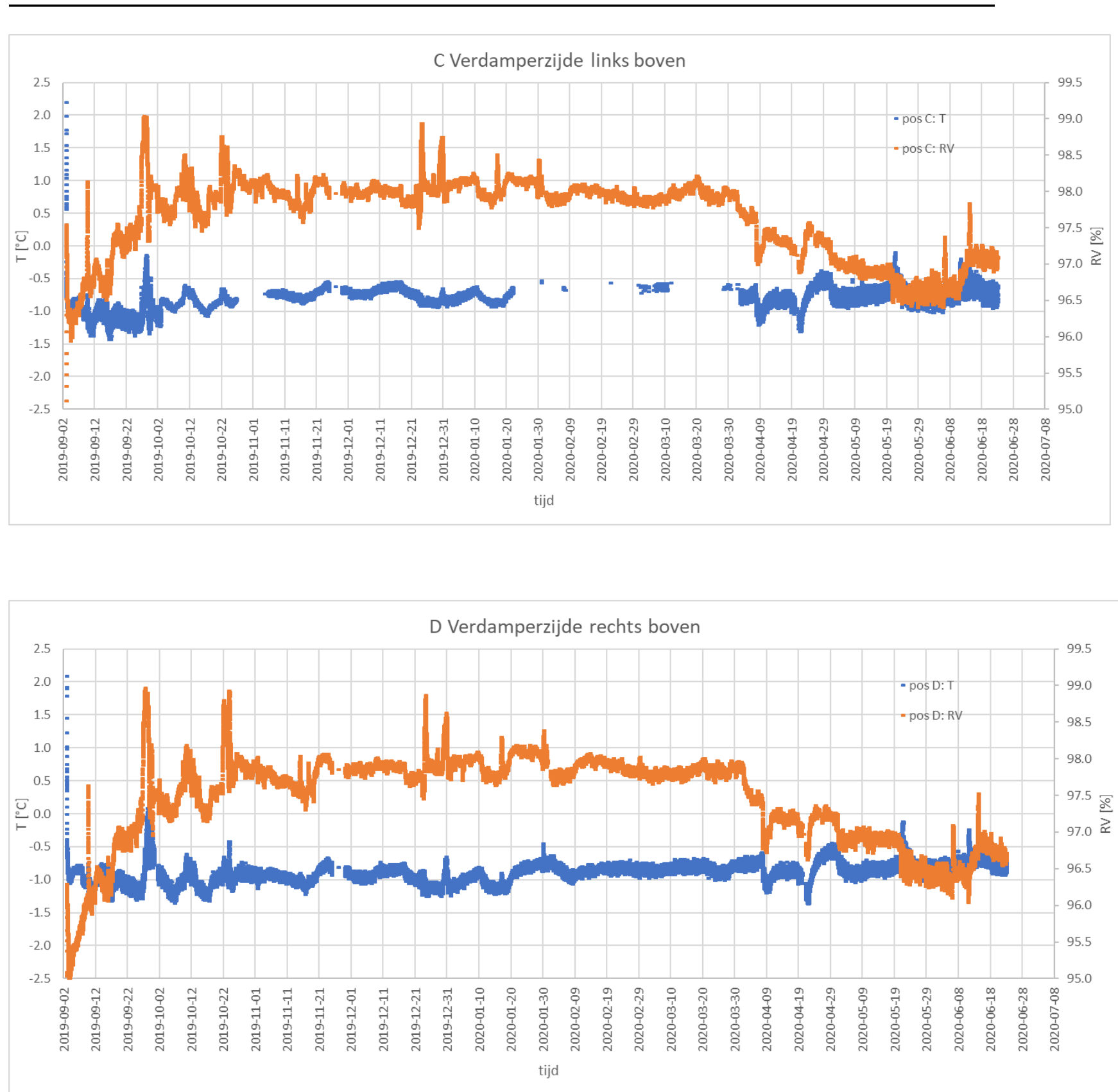


\section{E Deurzijde links boven}

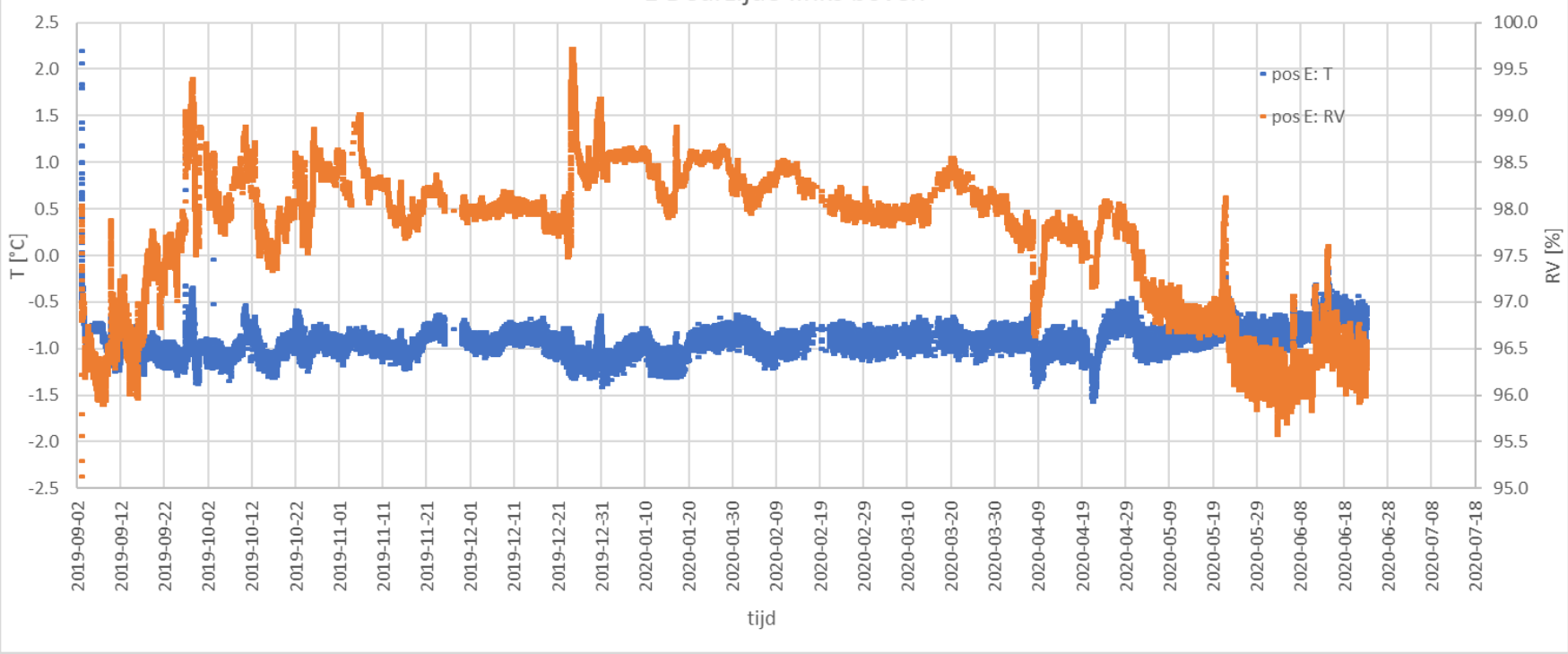

F Deurzijde rechts boven

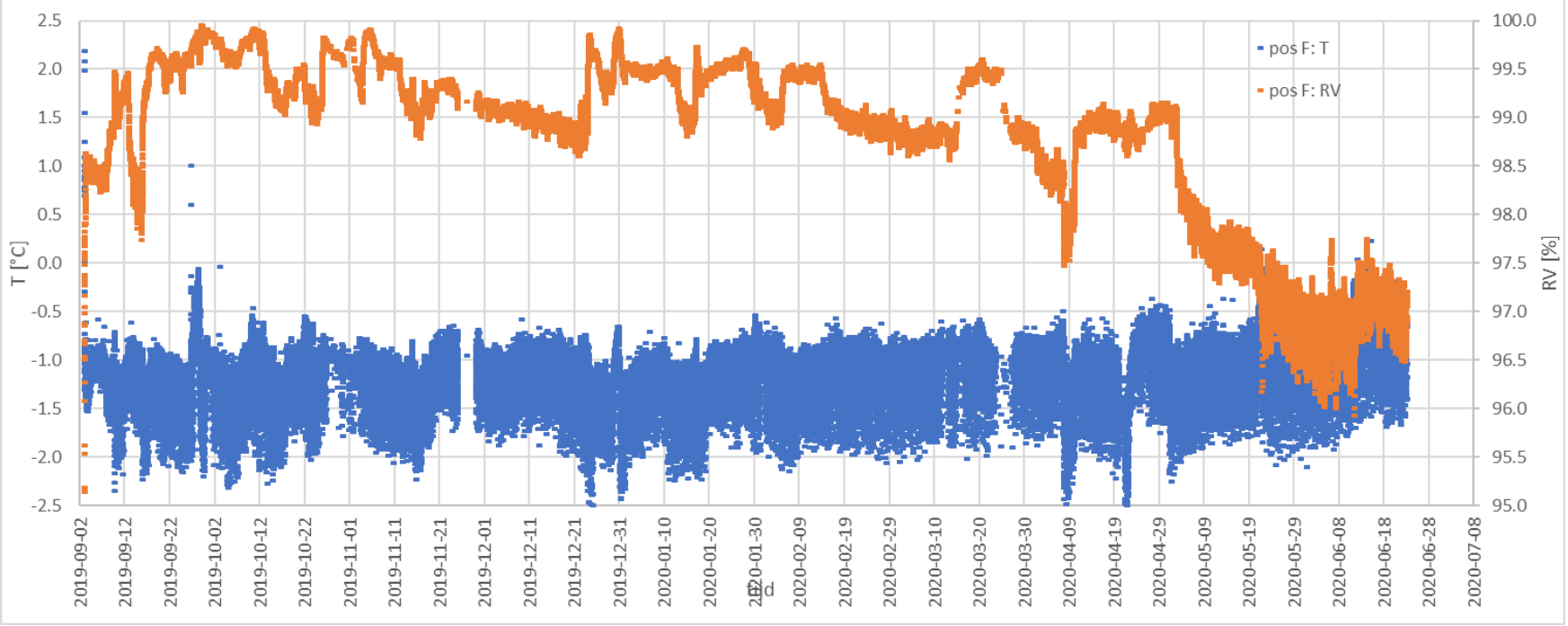

F Deurzijde rechts boven

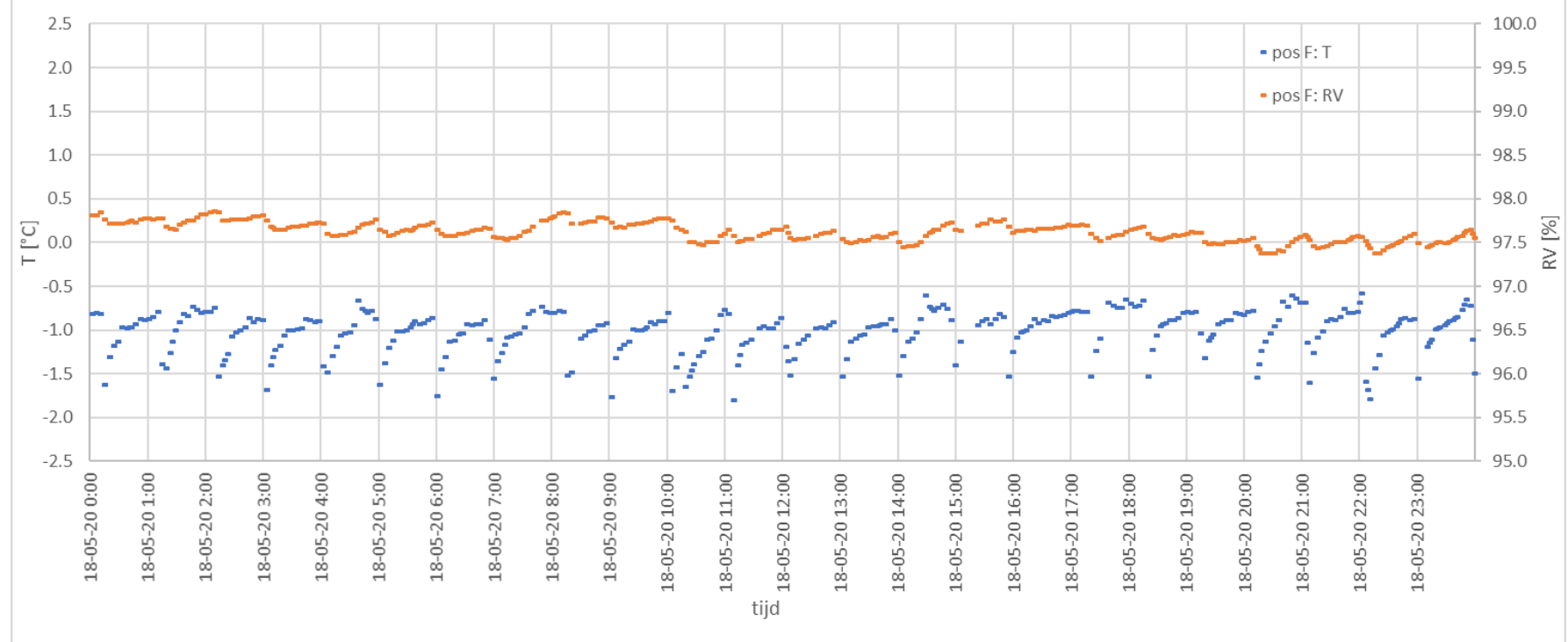






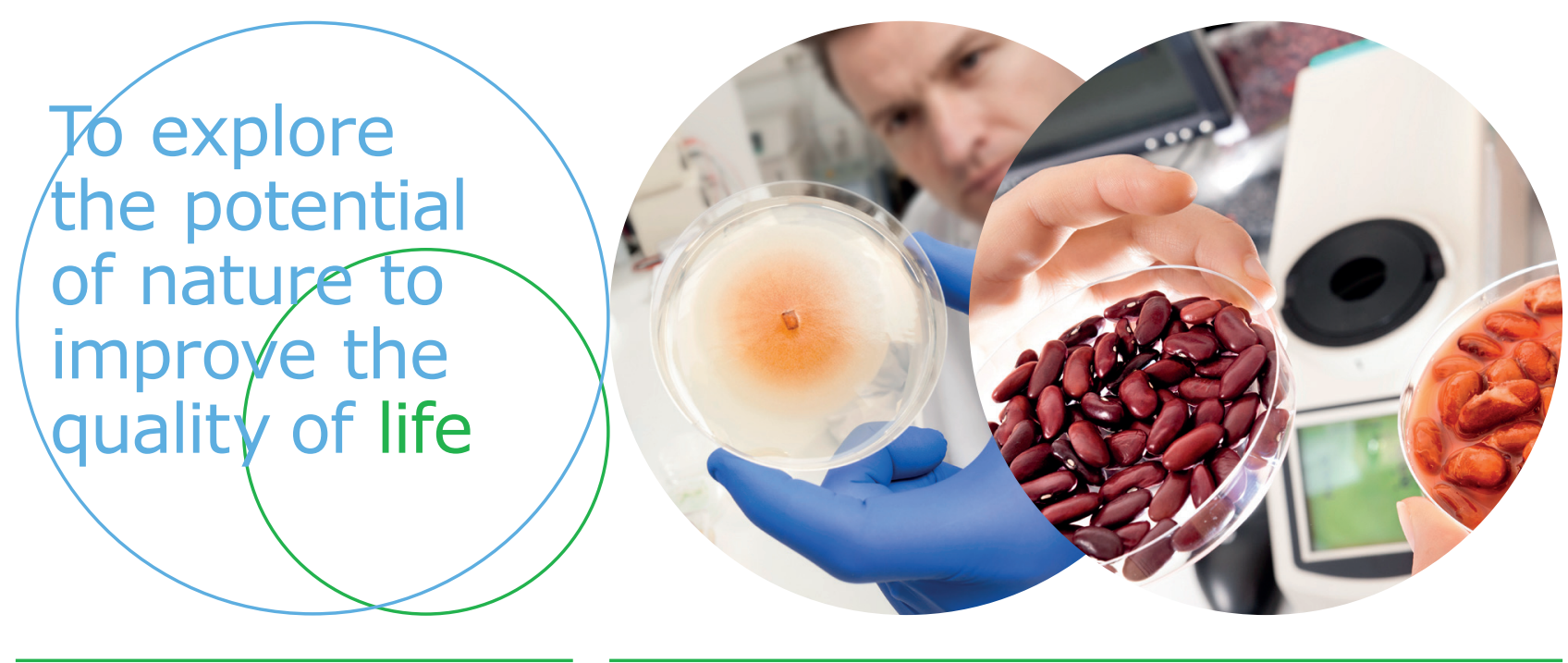

Wageningen Food \& Biobased Research Bornse Weilanden 9

6708 WG Wageningen

www.wur.nl/wfbr

info.wfbr@wur.nl

Rapport 2097

Vertrouwelijk
De missie van Wageningen University \& Research is 'To explore the potential of nature to improve the quality of life'. Binnen Wageningen University \& Research bundelen Wageningen University en gespecialiseerde onderzoeksinstituten van Stichting Wageningen Research hun krachten om bij te dragen aan de oplossing van belangrijke vragen in het domein van gezonde voeding en leefomgeving. Met ongeveer 30 vestigingen, 6.500 medewerkers (5.500 fte) en 12.500 studenten behoort Wageningen University \& Research wereldwijd tot de aansprekende kennisinstellingen binnen haar domein. De integrale benadering van de vraagstukken en de samenwerking tussen verschillende disciplines vormen het hart van de unieke Wageningen aanpak. 